\title{
Infancias, comunicación y educación: análisis de sus mutaciones
}

Juan Carlos Amador Baquiro

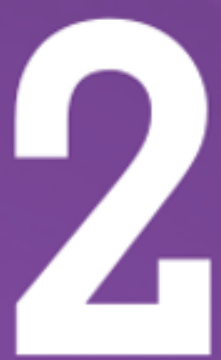

COLECCIÓN TESIS DOCTORAL 
INFANCIAS, COMUNICACIÓN Y EDUCACIÓN:

ANÁlisis DE SUS MUTACIONES 
INFANCIAS, COMUNICACIÓN Y EDUCACIÓN:

Análisis de sus mutaciones

\section{COLECCIÓN}

TESIS DOCTORAL

TESIS

DOCTORAL

PRESENTADA POR

JUAN CARLOS

AMADOR BAQUIRO

DIRIGIDA POR

Dr. Germán Muñoz

UNIVERSIDAD DISTRITAI Francisco José de CALdAS 


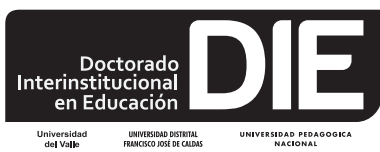

Universidad
del Valle

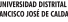

\section{Comité Editorial Interinstitucional-CAIDE}

Carlos Javier Mosquera Suárez

Director nacional

Germán Vargas Guillén

Coordinador DIE,

Universidad Pedagógica Nacional

Sandra Soler Castillo

Directora DIE,

Universidad Distrital Francisco José de Caldas

Jaime Humberto Leiva

Coordinador DIE,

Universidad del Valle

\section{Comité Editorial CADE}

Sandra Soler Castillo

Presidenta CADE

Álvaro García Martínez

Representante grupos de investigación Interculturalidad, Ciencia y Tecnología-INTERCITEC, y del Grupo Didáctica de la Química-DIDAQUIM, del Énfasis de Educación en Ciencias.

Sandra Soler Castillo

Representante de los grupos de investigación Identidad, Lenguaje y Cultura, Moralia, Estudios del Discurso, Educación Comunicación y Cultura del Énfasis de Lenguaje y Educación.

Olga Lucía León Corredor

Representante de los grupos de investigación Interdisciplinaria en Pedagogía de Lenguaje y las Matemáticas GIIPLyM, Matemáticas Escolares Universidad Distrital-MESCUD, del Énfasis de Educación

Matemática.

Rigoberto Castillo Representante de los grupos de investigación Formación de Educadores, del énfasis de Historia de la Educación, Pedagogía y Educación Comparada.
UNIVERSIDAD DISTRITAL

FRANCISCO JOSÉ DE CALDAS

\section{Roberto Vergara Portela}

Rector $(E)$

Universidad Distrital Francisco José de Caldas

\section{Boris Bustamante Bohórquez}

Vicerrector Académico

Universidad Distrital Francisco José de Caldas

ISBN impreso: 978-958-8832-39-5

ISBN digital: 978-958-8832-40-1

Primera edición, 2014

(C) U. Distrital Francisco José de Caldas

\section{Preparación Editorial}

Doctorado Interinstitucional en Educación Sede U. Distrital Francisco José de Caldas http://die.udistrital.edu.co

\section{Elban Gerardo Roa Díaz}

Asistente Editorial

eventosdie@udistrital.edu.co

\section{Fondo de publicaciones}

U. Distrital Francisco José de Caldas

Cra. 19 No. 33-39. Piso 2.

PBX: $(57+1)$ 3238400, ext. 6203

publicaciones@udistrital.edu.co

Corrección de estilo

Luisa Juliana Avella Vargas

Impreso en Javegraf

Bogotá, Colombia, 2014

Prohibida la reproducción total o parcial de la presente obra por cualquier medio sin permiso escrito de la Universidad Distrital Francisco José de Caldas. 


\section{CONTENI D O}

Primera parte. Mutación comunicacional

NUEVAS FORMAS DE RAZONAMIENTO

EN LA COMUNICACIÓN DIGITAL INTERACTIVA

GRAMÁTICAS DE ORDENACIÓN: LA RACIONALIDAD HIPERMEDIAL

RACIONALIDAD INTERACTIVA Y ARQUITECTURAS DE PARTICIPACIÓN

46

LOS SABERES: NUEVOS CAPITALES CULTURALES EN LA CDI

Saberes en torno a los usos y apropiaciones de la interfaz

64

Saberes en torno a contenidos y transmediaciones

66

Los saberes de la intertextualidad

70

Segunda parte. Mutaciones de la subjetividad 75

SUBJETIVIDADES HIPERMEDIALES

SABER, PODER Y SUBJETIVACIÓN

SUBJETIVIDADES SITUADAS $\quad 85$

$\begin{array}{ll}\text { El carácter hipermedial de la subjetividad } & 88\end{array}$

$\begin{array}{ll}\text { Subjetividades interactivas } & 93\end{array}$ 
Tercera parte. Otras educaciones y pedagogías

EDUCAR EN EL ACONTECIMIENTO

EDUCACIÓN CONVERGENTE

PEdAGogía DE LA PRESENCIA

Las simulaciones

La experiencia estética

130

MEDIACIONES PEDAGÓGICAS Y POTENCIACIÓN DE SUJETOS

139

(HIPER) MEDIACIONES PEDAGÓGICAS E INTELIGENCIA COLECTIVA

Elementos de las (hiper) mediaciones pedagógicas

151

EPÍLOGO

REFERENCIAS

\section{LISTA DE TABLAS}

Tabla 1: Síntesis mutación comunicacional

Tabla 2: Síntesis mutaciones de la subjetividad

Tabla 3: Mutación comunicacional 1: racionalidad hipermedial

Tabla 4: Mutación comunicacional 2: racionalidad interactiva

Tabla 5: Mutación comunicacional 3: saberes (nuevos capitales culturales) 


\section{AGRADECIMIENTOS}

Al Doctor Germán Muñoz: maestro, guía y amigo.

A los niños y niñas Dany, Daniel, Camilo, Maka y Valeria: sujetos con voz propia, portadores de experiencias y saberes.

A la Doctora Sandra Carli y los Doctores Jaime Alejandro Rodríguez y Alfonso Cárdenas, evaluadores de esta tesis y generosos interlocutores de ideas.

A los profesores del Énfasis de Lenguaje y Educación del Doctorado Institucional en Educación, sedes Universidad Distrital y Universidad Pedagógica Nacional.

A mis colegas y amigos, con quienes conversé y debatí durante el tiempo de la investigación y la escritura de este texto: Marieta Quintero, Zandra Pedraza, Borys Bustamante, Antonio Quintana, Pilar Albadán, Carlos Jilmar Díaz, Mario Montoya y Carlos Reina.

Al equipo administrativo del DIE.

A mis estudiantes de los programas de la Universidad Distrital Francisco José de Caldas: Licenciatura en Pedagogía Infantil; Licenciatura en Ciencias Sociales; Especialización en Infancia, Cultura y Desarrollo; Maestría en Investigación Social Interdisciplinaria; y Maestría en Comunicación-Educación. 
La infancia, la comunicación y la educación han sido protagonistas en las agendas de la política pública durante las dos últimas décadas en la mayoría de países del mundo. También han sido objetos de estudio centrales en disciplinas como la sociología, la psicología, la antropología y la pedagogía. Recientemente han sido incorporados a campos de investigación de carácter interdisciplinario como los estudios culturales, los estudios de la comunicación, los estudios sobre la infancia y las neurociencias. Finalmente, tanto entidades del Estado como organismos multilaterales y corporaciones transnacionales, motivados por distintos intereses, han expresado que los tres, si son estimulados y potencializados, podrán favorecer el desarrollo y el progreso de las sociedades.

Esta mirada preliminar permite evidenciar que existe una preocupación creciente por estos temas y sus transformaciones. Asimismo, se puede deducir que hacen parte de un núcleo de inquietudes fundamentales en torno a la capacidad de las instituciones y la sociedad civil para responder a las nuevas expresiones de los sujetos en el ámbito cultural. Frente a estos desafíos y las posibles relaciones entre los tres conceptos, surgen frecuentemente dos posiciones: sorpresa ante la novedad o preocupación ante la crisis. 
En relación con la novedad, se puede observar que nunca antes como en las últimas dos décadas se había imaginado futuro tan promisorio, gracias a las nuevas formas de comunicación y las tecnologías digitales. Se presupone que en este nuevo entorno comunicacional-tecnológico los niños, niñas y jóvenes, convertidos ahora en nativos digitales, podrán enfrentar los desafíos de la sociedad del conocimiento. En el lado opuesto, quienes se ubican en el ángulo de la crisis, toman estas expresiones emergentes como nocivas y empobrecedoras: su efecto inminente es la pérdida de valores.

Aunque los tres conceptos han sido ampliamente estudiados, pocos trabajos han indagado por sus articulaciones y tensiones. Las investigaciones sobre niños y niñas generalmente apelan al estudio de sus condiciones de vulnerabilidad, a los desafíos que suponen la garantía y restitución de sus derechos, a los efectos del mercado en sus identidades, así como a la necesidad de modernizar la escuela para que responda a estas problemáticas a la vez que fomenta sus capacidades productivas. La literatura muestra que han sido introducidos apelativos que buscan marcar la existencia de una diferencia generacional sin precedentes: generación Z, generación Einstein, generación @, generación interactiva, generación multimedia, generación multitasking, entre otras.

Los estudios de la comunicación, aunque contienen diversas tradiciones (informacional, crítica, semiótico-discursiva, estudios culturales, comunicación-cultura, comunicación-educación), han situado sus preocupaciones especialmente en los efectos de los mensajes, en el acto de recepción pasiva de las audiencias y en los consumos culturales de los receptores, aunque también proponen hablar del «emirec» (emisor y receptor a la vez). Recientemente, bajo las condiciones socio-políticas y económicas que conforman el ecosistema comunicacional contemporáneo, han surgido nuevas perspectivas que revalúan teorías anteriores y que están fomentando otros objetos de estudio, asociados frecuentemente con la Web 2.0 ${ }^{1}$.

Por su parte, los estudios sobre la educación (frecuentemente reducida a la escuela), en medio de sus matices, se han ocupado de explicar en cla-

\footnotetext{
' En el momento de escribir la última versión de este trabajo, se evidencia una discusión entre quienes aseguran que ya está entre nosotros la Web 3.0, mientras que otros continúan refiriéndose a la Web 2.0. Dadas las precauciones que deben ser tenidas en cuenta en este tipo de temas, en adelante se continuará empleando el término Web 2.0.
} 
ve histórica y arqueológica su estructura disciplinaria para comprender cómo esta incide en las subjetividades de los niños y niñas. Igualmente, se encuentran estudios sobre sus fundamentos y modos de funcionamiento (currículo, modelos pedagógicos, didácticas y evaluación), así como numerosas investigaciones sobre los profesores, sus creencias, saberes y prácticas. Sin embargo, al intentar reconocer los modos como se ha estudiado al sujeto de la educación (niños y niñas), se observa que sus principales acercamientos han estado ligados a aspectos como los estilos de aprendizaje, las alteraciones del desarrollo y los medios necesarios para regular sus tiempos y espacios en el contexto escolar.

En medio de las tensiones internas y las fuertes presiones que provienen de sectores externos, la escuela se ha volcado a implementar varias estrategias. Una de ellas tiene que ver con la introducción de tecnologías de la información y la comunicación como mecanismo para modernizarse y favorecer aprendizajes en los estudiantes. Por esta razón son crecientes los estudios y las teorías alusivas a la conveniencia de incluir máquinas, software e Internet en el espacio educativo y optimizar así la enseñanza de las asignaturas del plan de estudios convencional ${ }^{2}$.

Este panorama plantea varias inquietudes, y con el propósito de avanzar en la demarcación del objeto de estudio de la presente investigación, vale destacar algunas: ¿Qué cambios se están produciendo en los niños y las niñas en el tiempo presente? ¿Qué relación existe entre estos cambios y sus subjetividades? ¿Qué transformaciones trae consigo en la vida social y cultural la presencia del nuevo ecosistema comunicacional? ¿Qué piensan, sienten, valoran y hacen los niños y niñas en este entorno socio-técnico-cultural?

¿Qué relación existe entre las transformaciones provocadas por las nuevas formas de comunicación mediada tecnológicamente y las subjetividades de los niños y niñas? ¿La educación que orienta e implementa la escuela responde hoy a estas nuevas realidades? ¿Qué ocurre al incorporar computadores

\footnotetext{
${ }^{2}$ De entrada es importante señalar que este estudio no detallará las teorías, experiencias e investigaciones sobre la llamada educación virtual en la educación superior y sus derivados (e-learning, b-learning, multimodal, etc), la cual se ha valido hasta el momento de plataformas virtuales para su funcionamiento. Aunque estos modelos han mostrado potencialidades, también han servido como instrumento para profundizar la mercantilización de la educación, ampliando cobertura y disminuyendo profesores.
} 
y garantizar conectividad en las prácticas pedagógicas? ¿Es posible plantear una ruta para transformar las prácticas pedagógicas en la escuela?

Aunque todas estas preguntas no van a ser resueltas completamente, la presente investigación se inscribe en el marco de estas preocupaciones. Se trata de un objeto de estudio que proviene de dos trayectorias de investigación. En primer lugar, de una iniciativa que está vinculada a la línea de investigación Comunicación y Educación en la Cultura, la cual hace parte del énfasis de Lenguaje y Educación del Doctorado Interinstitucional en Educación (Universidad Distrital, Universidad Pedagógica Nacional y Universidad del Valle, Colombia) ${ }^{3}$. Y en segundo lugar, los estudios sobre infancia, educación y subjetividades del autor de esta tesis, adelantados en la Universidad Distrital Francisco José de Caldas y otras instituciones durante los últimos seis años ${ }^{4}$.

Apoyados en las consideraciones anteriores, la investigación propuesta busca establecer las relaciones posibles entre las expresiones contemporáneas que surgen de cada uno de estos tres conceptos, así como de sus fenómenos asociados. Los niños y niñas han modificado sus formas de conocer, ser y estar en el mundo a partir de nuevas experiencias que vinculan la cultura y la comunicación. Esta última también ha ingresado en una etapa de reconfiguración, dada la presencia de nuevas prácticas sociales, sensibilidades y formas de acceso al saber que hoy tienen lugar en los espacios-tiempos del mundo digital-virtual y transmediático.

La educación, por su parte, pasa por una ambivalente situación de crisis y potencialidades. Mientras que las instituciones de educación básica y superior evidencian limitaciones para lograr que sus estudiantes sean productivos, debido en buena medida a sus distancias frente a los mundos de vida de los niños, niñas y jóvenes, la educación en un sentido más amplio (fuera de las instituciones) está encontrando otros modos de funcionamiento y proyección.

\footnotetext{
${ }^{3}$ Esta línea de investigación la dirige el profesor Germán Muñoz. Se trata de una línea que está apoyada en la trayectoria del grupo de investigación Jóvenes, culturas y poderes (ver GRUPLAC).

${ }^{4} \mathrm{Al}$ respecto es importante destacar algunos estudios en el campo que fueron desarrollados en el periodo 2008-20II, apoyados por el Centro de Investigaciones de la Universidad Distrital y el Instituto de Paz IPAZUD de esta misma Universidad (Emergencias de la memoria: dos estudios sobre la escuela, la infancia y la violencia, 2009; La subordinación de la infancia como parámetro biopolítico y diferencia colonial en Colombia, 2009; El discurso vacío de la infancia y la juventud, 2010; Infancia y Cibercultura, 201I; Jóvenes y derechos en la acción colectiva, 20II).
} 
Se trata de teorías, experiencias y proyectos que muestran la potencialidad de las nuevas formas de comunicación para la producción de saberes, la gestión de ideas e iniciativas, y el fomento de la creación mediante la acción de redes y comunidades virtuales.

Por consiguiente, es necesario repensar la educación de los niños y niñas del tiempo presente. Se trata de explorar algunas de estas transformaciones en sus potencialidades: cambios de orden socio-cultural (con énfasis en la relación entre producción cultural y comunicación); cambios de carácter comunicacional propiamente dichos (indagando las experiencias de los niños y niñas en los espacios-tiempos digitales, interactivos e hipermediales); y cambios del sujeto-niño (como aproximación a las principales expresiones de su subjetividad).

Basados en el análisis de estos cambios, será posible establecer la pertinencia de las acciones en instituciones que gobiernan a la infancia. Finalmente, reconociendo parte de este universo de nuevos lenguajes, saberes y experiencias, se podrá proponer otros modos de concebir la educación y otras formas de asumir las prácticas pedagógicas en la escuela.

Con el fin de avanzar en la delimitación del problema de investigación, conviene presentar algunas aproximaciones conceptuales que, tratadas preliminarmente, permitirán comprender la ruta teórica y metodológica seleccionada. Tal como lo plantea el título del trabajo, se fijará la atención en tres grandes asuntos: las infancias, la comunicación y la educación.

Infancias: la introducción de esta palabra busca explicitar el carácter plural y diverso de niños y niñas. La infancia - en singular- se concibe en el mundo europeo desde el siglo xvi como la expresión de sujetos inferiores, que debían ser objeto de protección y cuidado de las nodrizas, los instructores y las instituciones de educación. Con el surgimiento de la escuela moderna en el siglo xviII, se profundizó la condición atávica de los niños, al quedar atrapados en sistemas de conocimientos y prácticas educativas adscritas a las etapas de la vida y al predominio de formas de enseñanza basadas en el enciclopedismo, el disciplinamiento y la normalización.

En el caso colombiano, la constitución de los niños y niñas no solo tuvo como referente estas orientaciones occidentales. Dada la experiencia colonial del pueblo colombiano, aspectos como la racialización, la higienización, la 
educalización y la judicialización fueron fundamentales en un proceso de configuración que conminó a estos sujetos a una subordinación naturalizada en el cuerpo social ${ }^{5}$. Producto de estas experiencias surgieron los niños abandonados, los niños guerreros y los niños trabajadores, problemáticas que en el tiempo presente aún persisten.

Sin desconocer la existencia de «infancias al extremo» ${ }^{6}$, es importante destacar que esta condición de subordinación naturalizada está cambiando. Aunque aún existen infancias vulneradas y explotadas, se está produciendo un proceso de transformación de los niños y las niñas que está ligado a la producción cultural y a prácticas comunicativas que operan en escenarios no institucionales. No se trata de un determinismo, pues la participación de estos sujetos en el mundo cultural y comunicacional ocurre con ocasión de otros acontecimientos de carácter más amplio, que dan cuenta también de la época.

Dentro de estos acontecimientos se destacan el desplazamiento del estado-centrismo al socio-centrismo; un cambio cultural basado en nuevas formas de comunicación que convierten a estos sujetos en mutantes con capacidad para producir nuevos lenguajes y saberes; modificaciones sustanciales en las familias y las prácticas de crianza; y la crisis de una escuela que ya no responde a los intereses y necesidades de los niños y niñas.

En conclusión, se puede afirmar que se trata del fin de la infancia moderna y el debilitamiento progresivo de instituciones que, aunque pretenden el gobierno de los niños y niñas, ya no pueden garantizar el control social como en otros tiempos. Este síntoma socio-cultural se expresa en un divorcio marcado entre la subjetividad moderna que la escuela aún pretende fomentar y las subjetividades emergentes de las generaciones que nacieron y crecieron en medio de los cambios culturales provocados por las nuevas formas de

${ }^{5}$ Estos términos hacen alusión a la implementación de intervenciones en los niños y niñas, desarrolladas a lo largo de la primera mitad del siglo xx. Racializar, higienizar, educalizar, entre otras acepciones, aluden a un conjunto de procedimientos que se ejercen sobre el cuerpo del niño para garantizar su normalización. Como se observará más adelante, este fue un proceso recurrente en varios países de la región (Amador, 2009).

${ }^{6}$ Este es un término propuesto para referir a la existencia de niños y niñas en condiciones de explotación y vulneración. Específicamente, es una condición que debe situarse en el contexto de los conflictos social y armado. Este concepto fue desarrollado en el marco de la investigación Emergencias de la memoria (Díaz y Amador, 2009). 
comunicación y las tecnologías digitales, entre otros fenómenos del mundo contemporáneo7.

Más allá de considerarlos nativos digitales dadas sus nuevas habilidades, se trata de comprender a dichos sujetos con otras formas de ser, pensar y actuar. Esto permite afirmar que no es posible seguir declarando la existencia de la infancia o la niñez en singular. Como se observará más adelante, las infancias contemporáneas plantean grandes desafíos a la sociedad y a las instituciones que pretenden gobernarlas.

La escuela es la más comprometida en esta interpelación pues, extrañamente, mientras persiste en el sostenimiento de rituales adscritos a los valores del Estado nacional (izar la bandera, hacer filas, marchar, clasificar, otorgar recompensas a los buenos muchachos, moralizar...), se ha involucrado (por imposiciones externas) en obligaciones inscritas en cuatro narrativas universales: el niño como sujeto de derechos; la formación ciudadana escolar; el fomento de la innovación y el pensamiento científico; y la cultura digital.

Comunicación: procedente de la raíz latina comunis, que significa «común» y «poner a la luz de todos», es entendida como un proceso humano, social y cultural que está adscrito a interacciones, sensibilidades, socialidades y tecnicidades (Martín-Barbero, 2003). Esto significa que la comunicación no puede ser reducida únicamente a medios, artefactos y transmisión de información. La comunicación es esencialmente un fenómeno inscrito en la producción cultural y, por su carácter interactivo, involucra siempre sujetos, grupos, discursos, imágenes y poderes. Se trata de un proceso central en la vida de los niños y niñas del siglo xxi, asunto que se evidencia en los lenguajes y saberes que producen en los entornos digitales que acompañan su existencia.

Son prolíficas las maneras de estudiar la comunicación. Una de ellas ha sido adelantada a través de grandes teorías gestadas en escuelas de pensamiento de todo el mundo. Las más conocidas son la conductista de Lasswell; la funcionalista de Lazarsfeld y Merton; la crítica de la Escuela de Frankfurt

\footnotetext{
7 Como se observará más adelante, este planteamiento tiene varios exponentes como Steinberg y Kincheloe (1997), Carli (2006), y Corea y Lewcowicz (2004). Particularmente, estos últimos plantean que la escuela se encuentra en crisis dada la distancia entre la subjetividad moderna y las subjetividades informacionales, las cuales proceden del mundo escolar y sus rituales así como de la cultura mediática y la vinculación creciente de los niños y niñas a esta.
} 
(Adorno y Horkheimer); la informacional de Shanon, Weaver y Wiener; la teoría de la comunicación humana de Bateson, Goffman y Birdwhistell; la estructuralista de Eco, Greimas y Barthes; la de los estudios culturales británicos (Hogart, Hall, Williams y Morley); la de los estudios culturales norteamericanos (Fiske, Radway, McRobbie y Barke); la economía política de la comunicación (Chomsky, Mastrini y Bolaño-Sequiera); y la comunicación-cultura en América Latina (Martín-Barbero, Prieto, Ortiz, Mattelard, Orozco, Muñoz).

De otra parte, tal como lo señaló Castells (2003) desde finales del siglo pasado, las generaciones más jóvenes han sido testigos de una revolución tecnológica que involucra microelectrónica, informática, optoelectrónica, telecomunicaciones y tecnologías de la vida. Esta revolución no es un determinante social y económico, sino más bien un acontecimiento que está inscrito en un contexto cultural que involucra sujetos, grupos y sociedades. Esto coincide con la noción de tecnicidad de Martín-Barbero (2003), quien afirma que las tecnologías no son condicionantes ni están en la exterioridad del mundo de la vida. Al ser parte de la producción cultural, se incorporan en las formas de percepción social, modificando las identidades y las subjetividades.

Recientemente han aparecido varias teorías para explicar estos fenómenos. Una de ellas, más que un sistema teórico, surge como marco de comprensión de las nuevas formas de comunicación en el contexto de la ampliación de las tecnologías digitales en la vida social. Se trata de una propuesta en consolidación llamada «hipermediaciones» o teoría de la comunicación digital interactiva (en adelante CDI) (Scolari, 2008), entendida como proceso de hibridación y contaminación de medios, mediaciones, formatos, géneros, prácticas y discursos, que tiene lugar en un espacio-tiempo digital, interactivo e hipermedial, que congrega sujetos, lenguajes, saberes, aprendizajes y proyectos.

Uno de los mayores aportes de la comunicación digital interactiva es que ubica en el centro de estos fenómenos la subjetividad humana y la capacidad de las personas para adelantar proyectos comunes mediante aplicaciones de la Web 2.o, especialmente a través de redes sociales, videojuegos, Wikis, blogs y fotologs, simulaciones y mundos virtuales. Para Scolari (2008), se trata de adaptar la categoría mediación de Martín-Barbero y actualizarla, (ya no vamos a mirar el paso «de los medios a las mediaciones» sino «de los 
nuevos medios a las hipermediaciones»), las cuales asumen convergencias ${ }^{8}$ no solo de orden técnico y digital, sino, ante todo, culturales.

Aunque son muchos los referentes que dialogan con esta perspectiva de la comunicación, es necesario aludir a algunos que complementan lo anunciado por Martín-Barbero (2003) y Scolari (2008). De una parte Pierre Lévy (2007), a través de su programa de la cibercultura, ha mostrado que no se trata de apelar a los dispositivos como el gran avatar que traerá consigo el desarrollo de las sociedades, sino de reconocer la composición de un entorno socio-técnico-cultural que favorece nuevas relaciones sociales, pero especialmente nuevas formas de creación estética y cultural mediante la noción de «inteligencia colectiva».

En segundo lugar, la búsqueda de un proceso democratizador a través de la comunicación, frente a los esfuerzos de diversos sectores en el mundo por el monopolio del conocimiento y las restricciones para el acceso a las aplicaciones de la Web 2.0, han provocado el surgimiento de movimientos como Cultura Libre (Lessig, 2004), Software Libre (Stallman, 2002), Manifiesto Rémix (2008) y Creative Commons, entre otros. Estos no solo fomentan la difusión del conocimiento existente en el mundo como patrimonio de la humanidad y derecho universal, sino que animan a la conformación de comunidades de práctica que sean capaces de producir saberes, compartir colaborativamente y generar acciones para la emancipación.

Finalmente, la modificación en las maneras de pensar y comprender el mundo, tras el ejercicio de nuevas prácticas sociales y comunicativas en la vida cotidiana de las personas, ha traído consigo a la escena académica el término transmediaciones (Jenkins, 2008). Se trata de experiencias comunicativas de carácter relacional, en las que se producen contenidos, textos y obras a partir de la articulación de diversos medios, formatos y dispositivos. Un ejemplo de este fenómeno lo provee la construcción de obras que vinculan filmografía, literatura convencional, hipertextos, videojuegos y mundos virtuales. Al incluir indicios y puzzles en cada escenario, las personas deben

${ }^{8}$ Las convergencias no solo aluden a lo digital (convergencia digital). Algunos autores proponen la noción convergencia cultural (Jenkins, 2008) para dar cuenta de las articulaciones y relaciones entre medios, mediaciones, contenidos e interacciones entre personas y grupos. 
comprender la obra en su conjunto (de manera intertextual) y participar en su intervención colectiva.

Educación: es un tema difícil de tratar, especialmente porque su definición en sí misma está ligada a «guiar» a los que lo necesitan e intervenir mentes y cuerpos a través de las instituciones de enseñanza. Como se observará más adelante, la escuela, comprendida como el espacio simbólico y social en el que se ejercen ciertas prácticas y circulan determinados saberes, fue diseñada (en su versión moderna) hace algo más de dos siglos para formar sujetos situados en circunstancias espaciales y temporales distintas a las del tiempo presente. El problema no es que haya surgido como consecuencia de los ideales del liberalismo (individualidad, obediencia, productividad, ciudadanía), sino que no haya sido capaz de transformarse en el tiempo.

Mario Kaplún (1998), hace algo más de dos décadas, señalaba que la educación podría resumirse en tres grandes modelos: educación basada en contenidos; educación centrada en resultados; y educación orientada por procesos. El primer modelo se ocupa de dar contenidos a aquellos que no los tienen (los alumnos), se concentra en la enseñanza enciclopédica de temas a través del discurso del profesor y del texto escolar, y promueve un esquema de comunicación transmisionista (emisor-receptor) 9 . El segundo modelo se basa en una educación por objetivos y hace énfasis en la eficacia del alumno para responder a las exigencias académicas mediante el entrenamiento, la ingeniería del comportamiento y los exámenes. Su forma de comunicación se apoya en la instrucción y la persuasión del profesor ${ }^{10}$.

El tercer modelo que planteaba Kaplún (1998) para introducir su perspectiva sobre la pedagogía de la comunicación y la comunicación popular se basa en lo que llamó énfasis en los procesos. Se trata de una práctica pedagógica orientada hacia la liberación, la cual funcionaría sobre la base de capacidades como la reflexión, la participación y la autogestión. En esta educación no hay contenidos preestablecidos ni cálculos determinados para enseñar de cierta manera. Los sujetos (estudiantes) son los protagonistas de sus propios

\footnotetext{
${ }^{9}$ Kaplún (1998) considera que este modelo está claramente explicado por Paulo Freire en su definición sobre educación bancaria.

${ }^{10}$ El ejemplo más claro lo provee la tecnología educativa, el estímulo respuesta y la taxonomía de objetivos de la tabla de Bloom.
} 
aprendizajes, los cuales se ponen a disposición de aquellos que lo necesiten. Sus principios de comunicación y acción son la cooperación y la solidaridad.

Estos importantes aportes de Kaplún (1998), además de continuar vigentes, contribuyen a la identificación de algunos de los desafíos más relevantes que hoy tiene la educación y la comunicación en el espacio escolar. Infortunadamente, aún predominan perspectivas que asumen el uso de las tecnologías de la información y la comunicación como instrumentos estratégicos para enseñar los mismos contenidos y enfoques de los planes de estudios convencionales. El uso de aparatos, e incluso el acceso a Internet, no siempre rebasan el transmisionismo y el instruccionismo de la escuela moderna ${ }^{11}$.

Basados en los cambios del tiempo presente y las subjetividades emergentes de los niños y niñas, es necesario considerar otras educaciones y otras pedagogías. El estatuto del conocimiento, el aprendizaje y el uso social de los saberes han rebasado la lógica de la institución educativa y la enseñanza de temas por parte del profesor. Los esfuerzos de diversos sectores (educadores populares, activistas, organizaciones de la sociedad civil, movimientos sociales, investigadores y jóvenes) han mostrado que es posible considerar otras formas de ejercer la educación como hecho social, político y cultural.

A manera de ilustración se pueden destacar perspectivas recientes, como la educación expandida (Proyecto Zemos98); el aprendizaje invisible (Cobo y Moravec, 2010); el aprendizaje ubicuo (Burbules, 2006); la edu-comunicación (Kaplún, 1998 Huergo, 2010; Prieto Castillo, 2010; Aparici, 2010); la educación en la frontera emocional (Ferrés, 2008); el proyecto posuniversidad y edupunk (Piscitelli, 2010, 2011); la educación, las pantallas y las transmediaciones (Orozco, 2010); las simulaciones digitales y la educación (Scolari, 2010); los videojuegos y la educación (Lacasa, 2011; Frasca, s.f), entre otros.

Aunque contienen enfoques distintos, estas propuestas coinciden en el interés de fomentar educaciones para mundos posibles basados en la interactividad, la hipermedialidad y la convergencia de las tecnologías digitales, así como en el papel protagónico de aprendizajes no formales (ni institucionalizados) para la formación de las personas. Por esta razón, su potencia está

"Por esta razón, el entusiasmo del Estado, de sectores de la sociedad civil y del mercado de hardware, software e Internet en torno al equipamiento y la conectividad, no son suficientes para superar estas miradas. 
en la producción (actitud prosumer) ${ }^{12}$ y no solo en la recepción y el consumo de información. De este modo, se promueven aprendizajes a partir de la exploración de problemas mediante interfaces gráficas que se relacionan con el mundo de la vida, la conformación de redes y comunidades para compartir saberes, y la promoción de proyectos cooperativos para la liberación

La delimitación de otras educaciones y pedagogías posibles, articuladas y contextualizadas con el cambio de época, requiere de un ejercicio investigativo de carácter inductivo. Esto significa que, indagando cuidadosamente las mutaciones socio-culturales y comunicacionales en cuestión como parte del espacio-tiempo en el que tramitan su existencia los niños y niñas, se pueden diseñar orientaciones para transformar la escuela en sus prácticas pedagógicas. Esto implica una transformación radical del mundo adultocéntrico y del gobierno de la infancia. Exige nuevos modos de percibir e interactuar con los niños y niñas. Requiere además reconocer no solo sus debilidades, sino especialmente sus potencialidades.

Como se podrá observar más adelante, el tratamiento de estos temas y problemas ha contado con diversos referentes teóricos y metodológicos para su estudio. Sin embargo, sus limitaciones estriban en la dificultad para investigarlos de manera relacional e interdisciplinaria. Por esta razón, la presente investigación busca analizar las transformaciones de carácter comunicacional (situadas en las experiencias producidas en la comunicación digital interactiva), como marco de comprensión para reconocer las subjetividades emergentes de los niños y niñas. Basados en estos hallazgos, se espera descubrir las interpelaciones subyacentes a las instituciones que gobiernan a la infancia, así como considerar otras educaciones y pedagogías posibles.

En términos más precisos, la pregunta de investigación que orientó el presente estudio fue: ¿De qué manera las mutaciones de carácter comunicacional (basadas en las experiencias producidas en la comunicación digital interactiva), asumidas como fuentes de nuevas subjetividades en los niños y niñas nacidos en la década del noventa en adelante, interpelan las instituciones que gobiernan la infancia y posibilitan otras educaciones y pedagogías?

\footnotetext{
${ }^{12}$ El término prosumidor, también conocido como prosumer, es un neologismo formado a partir de la fusión de las palabras en inglés producer (productor) y consumer (consumidor). Como se observará más adelante, se trata de acciones que agregan valor a un producto, servicio o al propio conocimiento. La actitud prosumer solo funciona mediante redes y comunidades, motivadas a trabajar alrededor de la colaboración y la difusión de ideas y proyectos comunes.
} 
Como objetivos, se precisaron: identificar los aspectos constitutivos de las experiencias comunicativas de los niños y niñas en el escenario de la comunicación digital interactiva, haciendo énfasis en los lenguajes, los saberes y las experiencias, como acercamiento al desciframiento de sus subjetividades; y explicitar las principales expresiones de las subjetividades emergentes de los niños y niñas a partir de las mutaciones analizadas (comunicacionales) con el fin de interpelar las instituciones que gobiernan la infancia y de proponer criterios para implementar otras educaciones y pedagogías posibles.

Como se puede apreciar, tanto los grandes conceptos enunciados desde el inicio como el problema de investigación, recogen transversalmente algunas categorías que resultan imprescindibles para emprender este camino: las subjetividades, las mutaciones y el tiempo presente. Aunque estas temáticas se desarrollarán más adelante, serán introducidas a continuación.

Las subjetividades son modos de ser y estar en el mundo, y remiten generalmente a la dimensión existencial del sujeto. Si bien el tema ha sido tratado a lo largo del tiempo por la metafísica, el psicoanálisis, el existencialismo, y recientemente por el llamado posestructuralismo, los hallazgos de este trabajo indican que la subjetividad debe ser analizada atendiendo a las relaciones posibles entre los modos de ser sujetos, la cultura, la experiencia y el lenguaje.

La subjetividad es una categoría analítica que busca dar cuenta de cómo el sujeto ha llegado a ser lo que es a partir de su propia historicidad (Foucault, 2005). Específicamente, la subjetividad es producida a través de las experiencias del sujeto en espacios y tiempos de diverso orden. Uno de esos escenarios son las instituciones modernas (manicomio, hospital, cuartel militar, fábrica y escuela), lugar en el que el sujeto es objeto de clasificaciones y procesos de normalización. La regulación de los tiempos y espacios que aquí se produce favorece la fabricación de sujetos obedientes y productivos. Foucault planteó que este orden en su conjunto puede ser llamado sociedad disciplinaria y que cuando esta llega al punto más alto, puede operar como biopolítica.

Dado que el sujeto no es pasivo y que no se trata de una entidad universal y racional, tal como lo declaró el proyecto de modernidad temprana desde el siglo xvII, es posible que la subjetividad humana sea mediada por experiencias de otras características, que no siempre sitúan al sujeto como efecto de fuerzas externas. Se trata de acontecimientos que afectan la vida y que pueden llegar a modificar sus modos de pensar y actuar. Al final de su obra, Foucault (1991) llamó a esta faceta de la subjetividad experiencia de sí; sospecha que 
posteriormente fue desarrollada bajo nuevas categorías y referentes por Gilles Deleuze y Félix Guattari (2008), entre otros. Aunque estas teorías hacen contribuciones fundamentales para abordar los problemas de la subjetividad, probablemente son insuficientes para indagar las relaciones entre infancias, comunicación y educación.

Algunos seguidores de esta tendencia, quienes han registrado acercamientos a la infancia y la escuela, han ubicado especialmente el primer nivel de la subjetividad (instituciones disciplinarias, fuerzas normalizadoras, discursos y prácticas), mostrando la importancia del saber (verdad) y las prácticas (de poder) en los procesos de constitución de sujetos. Por su parte, algunos estudios sobre comunicación, interesados en indagar la subjetividad en los nuevos escenarios virtuales e interactivos, muestran inquietudes similares, solo que actualizadas bajo los componentes de las sociedades de control $(\text { Deleuze, 2006) })^{13}$.

Como se observará más adelante, este modo de ver al sujeto muestra nuevas complejidades: identidades diversas, relativización del yo en las pantallas, prácticas y rituales éxtimos (Sibilia, 2008; Turckle, 1995), ficciones que distribuyen realidades conforme a grupos, entre otros. No obstante, una vez más, se trata de aproximaciones que sitúan al sujeto como una entidad pasiva que es fabricada bajo las intenciones de fuerzas externas, en este caso del mercado.

Aunque la escuela continúa funcionando bajo los principios del Estado nacional y su interés por consolidar la subjetividad universal del niño (postura alineada con las demás instituciones que buscan gobernarlo), las experiencias de estos sujetos se han ampliado a partir de su presencia en otros escenarios fuera de la institucionalidad. Tanto los hallazgos de esta investigación como otros estudios, indican que los mundos de vida de la infancia han adquirido, como consecuencia del cambio cultural, nuevas fuentes para la producción de la subjetividad. Dentro de estas fuentes se encuentran las nuevas prácticas de crianza; el conflicto social y armado; las experiencias estéticas; la complejidad de lo urbano; las diversas formas de consumo; y las nuevas expresiones de la comunicación.

${ }^{13}$ Como se verá más adelante, las sociedades de control son escenarios más complejos que los de las sociedades disciplinarias de Foucault. Según Deleuze, el control ya no opera por la vía del encierro sino por la modulación del deseo, las pasiones y la memoria. 
Particularmente, el análisis de las subjetividades de los niños y las niñas en espacios digitales, interactivos e hipermediales requiere incluir la cultura y la comunicación como elementos centrales de su construcción. La producción de la subjetividad en generaciones anteriores estuvo preferiblemente mediada por la familia, la escuela, la iglesia, y en algunos casos por el mundo de la calle (específicamente para los niños y niñas urbanos). Las generaciones que han nacido y crecido en medio de estas transformaciones culturales y comunicacionales (concretamente a partir de la década del noventa en el caso colombiano), al ingresar en espacios y tiempos que proveen nuevas experiencias, han ido construyendo otro tipo de subjetividades.

Por esta razón, la aproximación propuesta aquí para indagar las subjetividades de las infancias contemporáneas parte de una valoración especial de la cultura como vector de la vida humana y social. En la cultura ocurren tres fenómenos fundamentales como aporte a la construcción de estas subjetividades: los artefactos, las tecnologías y los medios son parte de la trama cultural y de las acciones humanas (no son externos a la vida); los sujetos ejercen usos y apropiaciones de lo que consumen, situación que afecta sus percepciones de espacio y tiempo, dando lugar a nuevas socialidades, sensibilidades y formas de acceso al saber; las experiencias comunicacionales (digitales e interactivas) fomentan nuevas formas de razonamiento (polifónicas e intertextuales) y otros capitales culturales.

La segunda categoría transversal anunciada es la mutación. El término mutación está referido a transformaciones, cambios y novedades. Alessandro Baricco (2008) lo ha propuesto recientemente, basado en un análisis ingenioso de diversos fenómenos de la cultura que expresan modificaciones no solo de prácticas, sino de mentalidades y modos de ver el mundo. Baricco emplea el término bárbaros con el fin de mostrar, apelando a esta inusual metáfora, que los mutantes son exploradores, navegantes y surfistas. Su principal característica es que transitan por sistemas de paso e introducen prácticas que, en un momento dado, pueden llegar a trastocar los valores y las creencias instituidas. Sin embargo, luego, pueden convertirse en importantes innovaciones para el funcionamiento de la sociedad.

Las mutaciones, término situado inicialmente dentro de un sistema de conocimientos relativo a la biología y la genética, es entendido como un conjunto de alteraciones o cambios relacionados con la información genética de un ser vivo. Lo interesante de estos cambios es que se presentan súbita 
y espontáneamente, pero logran un impacto tan especial que pueden ser transmitidos a las demás generaciones. Aunque una consecuencia de las mutaciones puede ser la presencia de enfermedades genéticas (en el corto plazo), estas terminan convirtiéndose en procesos esenciales para la existencia, pues sin alteraciones de esta naturaleza la vida no podría evolucionar.

Análogamente, las mutaciones en el contexto de los estudios de la cultura, la comunicación y la educación pueden entenderse como fenómenos emergentes que, aunque implican novedad, también contienen elementos del pasado. Por esta razón, el análisis de las mutaciones de orden social y ontológico debe realizarse atendiendo no solo a las expresiones de los cambios sino a los modos como los hechos del pasado se sedimentan y hacen posible la cristalización de lo diferente. Generalmente, pese a la persistencia de la tradición y los valores, el surgimiento del acontecimiento, comprendido como algo que puede ser creado en el orden de lo posible (Bajtin, 1997; Lazzarato, 2006), propicia experiencias y lenguajes para el surgimiento de la potencia.

Finalmente, en relación con la tercera categoría transversal llamada tiempo presente, se puede afirmar que es un término tratado por disciplinas y campos como la historia, la sociología, la antropología y los estudios culturales. Para Beatriz Sarlo (2010), el tiempo presente no es estrictamente un periodo de tiempo ni una delimitación específica de lo actual. Se trata más bien de una lectura de la cultura contemporánea efectuada desde el propio presente para lograr comprender su fugacidad y su inmediatez, en el contexto de una historicidad que fluye múltiple y que hace énfasis en la producción cultural como vector del cambio y de la vida social, política, económica y tecnológica.

Desde luego que el tiempo presente introduce debates difíciles de abordar, dado su carácter transicional y sus frecuentes relaciones con nuevas percepciones sociales expresadas en lenguajes, saberes, temporalidades y territorialidades. Para efectos de este trabajo, el tiempo presente alude a una época en la que nació y creció una generación en medio de grandes transformaciones culturales. Parte de estas transformaciones está constituida por sucesos paradójicos: un repertorio audiovisual y transmediático sin precedentes, así como sucesos de crisis económica y violencia que afectaron el orden social colombiano.

La indagación de los fenómenos del tiempo presente ha mostrado progresos significativos en los últimos años. Un elemento común de este tipo de 
trabajos es la incorporación de los términos tránsitos y transiciones. Esto significa que su interés se centra en abordar el cambio y las mutaciones. Los fenómenos que investiga, aunque son evanescentes y se encuentran en proceso de cristalización, son comprendidos a partir de sedimentaciones que se producen en el tiempo y que se expresan en el presente. De esta manera, la lectura del presente en sus ritmos acelerados es siempre un esfuerzo por observar la transformación del pretérito y su correspondiente actualización.

En América Latina y el Caribe han sido explorados especialmente tránsitos y transicionesdel estadocentrismo al sociocentrismo; de las dictaduras a la democratización; del patriarcalismo a la diversidad sexual; de los partidos a la acción colectiva de nuevos movimientos sociales, entre otras. A este conjunto de fenómenos emergentes, objeto de estudio preferido del tiempo presente, deben incluirse otras manifestaciones contemporáneas como el tránsito de la infancia moderna a las nuevas infancias (Diker, 2008), el tránsito de los medios a las mediaciones (Martín-Barbero, 2003), el tránsito de las mediaciones a las hipermediaciones (Scolari, 2008), y el tránsito de la escuela moderna a educaciones y pedagogías otras.

\section{SISTEMA METODOLÓGICO}

Para cerrar esta introducción es necesario exponer de manera breve el sistema metodológico implementado con el fin de abordar el problema de investigación y sus objetivos. Como se puede observar, tanto las expresiones de la subjetividad como la construcción de orientaciones educativas y pedagógicas, requiere el abordaje inicial de lo que aquí han sido llamadas mutaciones comunicacionales.

De esta manera, la investigación se centró en los aspectos constitutivos de las prácticas de los niños y niñas en la comunicación digital interactiva (CDI-hipermediaciones), asumida como un escenario que propicia nuevos lenguajes, saberes y experiencias. En este caso, la comprensión fenomenológica de estas prácticas comunicacionales permitió descifrar algunas de las expresiones más relevantes de las subjetividades emergentes de estos sujetos.

El análisis de prácticas comunicacionales, centradas en las posibles relaciones entre niños y niñas y espacios pantallizados, hipermediados e hiperconectados, exigió abordar de manera preliminar dos grandes categorías para 
los procesos de registro e interpretación correspondientes: la construcción de nuevas formas simbólicas (comprendidas como unidades de expresión y de acción que se nutren de la cultura, pero que también la recrean, según Cassirer, 2003); y la producción de saberes, entendidos como criterios que son acumulables y utilizables para la acción social. Particularmente, esta noción de saberes se apoya tanto en la tesis de Bourdieu (2010) sobre capital cultural como en los planteamientos de Lévy (2004) sobre inteligencia colectiva.

Tanto las formas simbólicas como los saberes que son producidos por los sujetos ratifican sus modos de ser y estar en el mundo, y se convierten en orientadores fundamentales para construir la experiencia y la conciencia. Por esta razón, lenguaje, saberes y existencia constituyen la base de aproximación a la subjetividad. Las prácticas comunicacionales en las hipermediaciones posibilitan que los sujetos construyan condiciones de existencia que les permita reconocerse, descifrarse y reafirmarse.

Dado que la indagación de las prácticas en la comunicación digital interactiva implica explorar las dimensiones interactivas, hipertextuales e hipermediales de las nuevas formas de comunicación en la Web 2.0, el escenario privilegiado de observación fue la red social Facebook. Como es sabido, se trata de una de las redes sociales más populares de los últimos cinco años en el mundo y una herramienta que permite reconocer interacciones comunicativas de los participantes con otros sujetos y grupos, así como con otros sitios de Internet, gracias a sus opciones de convergencia digital.

En consecuencia, fue empleado el método llamado etnografía virtual. Según Cristine Hine (2004, p. 17), el uso de la etnografía en el mundo de la Web sirve para alcanzar un sentido enriquecido de los significados que va adquiriendo la tecnología en las culturas que la alojan o que se conforman gracias a ella. Esa perspectiva implica diferenciar dos modos posibles de hacer etnografía virtual: etnografías que parten de entender Internet como cultura (ciberespacio); y etnografías que conciben el mundo www como artefacto cultural.

Mientras que la primera plantea la necesidad de reconocer la Internet como cultura y espacio social en el que se producen significados compartidos (lenguajes compartidos, sistemas de desciframiento de signos, conformación de comunidades y construcción de identidades), la segunda busca comprender no solo la naturaleza de las prácticas e interacciones producidas por sujetos y grupos, sino abordar el conjunto de discursos, representaciones e 
imaginarios que le dan forma y constitución a la tecnología y sus conexiones. La etnografía virtual se opone a marcar distinciones entre los niveles online y offline para realizar investigaciones, dado que busca reconocer las interconexiones entre estas dos realidades a través de la interacción del investigador en la Web (Hine, 2004, p. 40).

Si la premisa fundamental de esta etnografía es que el investigador sea quien se ocupe de interpretar el sistema de prácticas que opera en la vida online de las personas, la ruta metodológica de esta mutación requería una condición obligatoria: establecer interacción online entre el investigador y los participantes. Por esta razón fue conformado un grupo de niños y niñas que viven en Bogotá, pero que poseen diversas condiciones que han incidido en la construcción de sus mundos de vida.

Se trata de niños que, en el periodo de interacción de esta parte de la investigación (cuatro meses aproximadamente), tenían entre 11 y 14 años de edad $^{14}$. Su perfil es muy simple y puede ser similar al de muchos niños y niñas colombianos: estudian en colegios oficiales y privados de la ciudad; crecieron apreciando la oferta televisiva, cinematográfica y transmediática a partir de la década del noventa del siglo pasado; y también disfrutan haciendo otras actividades como leer, jugar, ir al centro comercial o al parque.

Particularmente, en sus prácticas comunicacionales, se destaca la presencia de diversos niveles de interactividad con y a través de redes sociales, videojuegos online, canales de video y música como YouTube y otros sitios de la Web 2.0 que les permiten seguir artistas y deportistas, retocar imágenes, editar videos, enlazarse a blogs y consultar Wikis como Wikipedia. La participación de Daniela, Daniel, Maka, Camilo Ryu Genkay y Valeria fue imprescindible para esta investigación, y su disposición para compartir lo que son y lo que hacen merece todo el reconocimiento y agradecimiento. También se agradece a sus padres y/o cuidadores por autorizar la publicación de algunos datos de sus hijos, a quienes siempre se les respeto su intimidad.

\footnotetext{
${ }^{14}$ Atendiendo a perspectivas en el campo de la sociología de la infancia y la juventud, particularmente apoyados en los estudios sobre generaciones de Carles Feixa (2002), se ha señalado que es necesario describir y analizar las prácticas sociales y la producción de sentido de aquellos sujetos que nacieron al final del milenio pasado y que hoy bordean edades entre los 10 y 15 años. Más allá de designarles un término (multimedia, @, interactiva, Z...) es necesario comprender sus lógicas de pensamiento, acción y subjetivación.
} 
En lo procedimental, la etnografía virtual se apoyó en cinco pasos claves: diseño de un repositorio de información; diseño de subcarpetas en la carpeta de cada participante, de acuerdo con las dos grandes categorías previstas (formas simbólicas y saberes); registro, vía pantallazos (ImpPnt), de las situaciones asociadas con niveles de uso o producción como la actualización y publicación de información, las conversaciones a través del chat, la organización de piezas digitales y enlaces, y evidencias de transmediación; clasificación de los pantallazos registrados en cada carpeta y subcarpeta; exploración de imágenes, fotografías y enlaces a videos y sitios Web de cada participante; y registro de evidencias de transmediación.

Tabla 1: Síntesis mutación comunicacional

\begin{tabular}{|c|c|c|}
\hline \multicolumn{3}{|c|}{ Mutación comunicacional } \\
\hline \multicolumn{3}{|c|}{ Método: etnografía virtual } \\
\hline Propósito & Conceptos clave & Preguntas articuladoras \\
\hline $\begin{array}{l}\text { Identificar los } \\
\text { aspectos cons- } \\
\text { titutivos de las } \\
\text { experiencias } \\
\text { comunicativas de } \\
\text { los niños y niñas } \\
\text { en la comuni- } \\
\text { cación digital } \\
\text { interactiva, } \\
\text { haciendo énfasis } \\
\text { en los lenguajes, } \\
\text { los saberes y las } \\
\text { experiencias, } \\
\text { para acercarnos } \\
\text { al desciframiento } \\
\text { de sus subjetivi- } \\
\text { dades. }\end{array}$ & $\begin{array}{l}\text { Formas simbólicas. } \\
\text { Saberes y capitales } \\
\text { culturales. } \\
\text { Experiencia. } \\
\text { Inteligencia colec- } \\
\text { tiva. } \\
\text { Comunicación digi- } \\
\text { tal interactiva. }\end{array}$ & $\begin{array}{l}\text { ¿Cuál es la naturaleza de las prácticas } \\
\text { comunicacionales de los niños y niñas en } \\
\text { Facebook? } \\
\text { ¿Qué relación existe entre estas prácticas y la } \\
\text { producción de sistemas simbólicos en estos } \\
\text { sujetos? } \\
\text { ¿Qué lenguajes y saberes son producidos y } \\
\text { tramitados por estos sujetos en el mundo de } \\
\text { la vida de la comunicación digital interacti- } \\
\text { va? } \\
\text { ¿Qué relación existe entre las prácticas } \\
\text { comunicativas en Facebook y la producción } \\
\text { de saberes? } \\
\text { ¿Qué convergencias y transmediaciones } \\
\text { subyacen a estos saberes? } \\
\text { ¿Qué relación existe entre estas prácticas } \\
\text { y las subjetividades emergentes de estos } \\
\text { sujetos? }\end{array}$ \\
\hline
\end{tabular}

Fuente: propuesta del autor

La segunda mutación, dedicada a las subjetividades de los niños y niñas, no empleó una ruta metodológica como tal. Simplemente fue organizada y develada a partir de los hallazgos de la primera. Lo que se hizo en esta parte de la investigación fue triangular los resultados de los niveles de análisis iniciales: experiencias basadas en lenguajes (formas simbólicas) y saberes (capitales culturales e inteligencias colectivas) a partir de las experiencias 
comunicacionales. Los dos niveles se convierten en fuentes de análisis de nuevas subjetividades y en un escenario amplio de constantes mutaciones.

Como se observará más adelante, la construcción (social y subjetiva) de la infancia no solo puede ser analizada a través de la acción de las instituciones disciplinarias o de los enunciados encargados de producir su subjetividad, comprendidos como procesos que evidentemente conducen a la implementación de formas de intervención institucional (Foucault, 2005). Otro modo de comprender la construcción de la infancia parte de los mundos de vida que estos sujetos producen en su cotidianidad.

Por tal razón, esta mutación de carácter ontológico, develada a partir del camino recorrido, fue organizada atendiendo a la emergencia de nuevas condiciones y experiencias que fueron constatadas en la primera. Se destacan las nuevas percepciones del tiempo y el espacio mediadas por el acceso a narrativas, géneros y formatos; la construcción de identificaciones sociales auspiciadas por nuevos sistemas de intereses y necesidades; la inmersión en transmediaciones que amplifican lo visual, lo auditivo y lo táctil; las prácticas hipertextuales e hipermediales que posibilitan arquitecturas de participación; y los saberes emergentes que se convierten en nuevos capitales culturales, entre otros.

La noción de subjetividades hipermediales e interactivas, planteadas más adelante, aluden al valor del lenguaje, los saberes y las experiencias como repertorio de posibilidades para la constitución singular y colectiva del sujeto, particularmente de los niños y niñas del tiempo presente que participan en el mundo de la comunicación digital interactiva. La filosofía del pensamiento menor (Lazzarato, 2006), en diálogo con la filosofía del acto ético de Mijail Bajtin (1997), plantea la importancia de este proceso de despliegue del sujeto a través de nociones como acontecimiento, plurilingüismo y polifonía de voces $^{15}$.

${ }^{15} \mathrm{El}$ acontecimiento, comprendido como algo que puede ser creado en el orden de lo posible, es potencialidad y mundo posible. Por esta razón, Bajtin se convierte en una voz imprescindible para este cometido al introducir las nociones de plurilingüismo y polifonía de voces. Se trata de la existencia de condiciones mínimas que permiten establecer las relaciones entre el yo y el otro. Esto significa que la fuente privilegiada en la producción del sentido no es la imagen ni el medio en sentido estricto, sino el mundo del otro. Sin embargo la relación con el otro no es armoniosa, no pretende crear subsunciones ni consensos. Lo que subyace de todo encuentro entre el yo y el otro son puntos de vista, que se incorporan al acontecimiento y que implican consecuencias. 
El yo comunicativo, digital e interactivo, que se está construyendo en el contexto de un programa cultural caracterizado por conexiones y flujos, según los hallazgos, trasciende el carácter solipsista del sujeto esencial de la modernidad. Es un sujeto que se incorpora en una estética de la existencia que no sólo le permite decir-se y nombrar-se sino inventar-se. De este modo, formas simbólicas y saberes se convierten en las fuentes fundamentales, orientadas por nuevos sistemas de intereses y necesidades, para favorecer el despliegue de la subjetividad y la posibilidad de transitar de un yo dado y constituido a un yo situado, encarnado, virtualizado y en construcción continua.

Tabla 2: Síntesis mutaciones de la subjetividad

\begin{tabular}{|c|c|c|}
\hline \multicolumn{3}{|c|}{ Mutaciones de la subjetividad } \\
\hline \multicolumn{3}{|c|}{$\begin{array}{c}\text { Referentes: filosofía del pensamiento menor y filosofía } \\
\text { del acto ético del sujeto }\end{array}$} \\
\hline Propósito & Conceptos clave & Preguntas articuladoras \\
\hline $\begin{array}{l}\text { Explicitar las principa- } \\
\text { les expresiones de las } \\
\text { subjetividades emergen- } \\
\text { tes de los niños y niñas a } \\
\text { partir de las mutaciones } \\
\text { analizadas (comunica- } \\
\text { cionales) con el fin de } \\
\text { interpelar las institu- } \\
\text { ciones que gobiernan la } \\
\text { infancia y de proponer } \\
\text { criterios para implemen- } \\
\text { tar otras educaciones y } \\
\text { pedagogías posibles. }\end{array}$ & $\begin{array}{l}\text { Acontecimiento. } \\
\text { Sujeto y subjetividad. } \\
\text { Lenguajes. } \\
\text { Saberes. } \\
\text { Experiencias. } \\
\text { Plurilingüismo. } \\
\text { Polifonía de voces. } \\
\text { Subjetividades situa- } \\
\text { das. } \\
\text { Subjetividad hiperme- } \\
\text { dial. } \\
\text { Subjetividad interac- } \\
\text { tiva. }\end{array}$ & $\begin{array}{l}\text { ¿Qué expresiones de la subjetivi- } \\
\text { dad se identifican en los aconteci- } \\
\text { mientos de los que participan los } \\
\text { niños y niñas, en el contexto de } \\
\text { las mutaciones socio-culturales } \\
\text { (cultura audiovisual y transme- } \\
\text { diaciones)? } \\
\text { ¿Qué expresiones de la subjetivi- } \\
\text { dad se identifican en los aconte- } \\
\text { cimientos de los que participan } \\
\text { los niños y niñas, en el contexto } \\
\text { de las mutaciones comunicacio- } \\
\text { nales? } \\
\text { ¿Qué expresiones de la subjetivi- } \\
\text { dad se identifican en los lenguajes } \\
\text { y saberes producidos por los } \\
\text { niños y niñas en la comunicación } \\
\text { digital interactiva? } \\
\text { ¿De qué manera estas subjetivi- } \\
\text { dades emergentes interpelan a las } \\
\text { instituciones de protección de los } \\
\text { niños y a la escuela moderna? } \\
\text { ¿Los rasgos de estas subjetivi- } \\
\text { dades emergentes proporcionan } \\
\text { elementos para considerar otras } \\
\text { educaciones y pedagogías posi- } \\
\text { bles? }\end{array}$ \\
\hline
\end{tabular}

Fuente: propuesta del autor 
A través de este mapa de sujeto y de subjetividades emergentes de las infancias contemporáneas, se procedió a la reflexión sobre la educación, la pedagogía y la escuela. Más allá de una propuesta pedagógica o de la exposición de un conjunto de prescripciones para enseñar utilizando artilugios, las dos mutaciones caracterizadas y analizadas permitieron, además de interpelar el papel de las instituciones modernas en su interés por sostener el gobierno de la infancia, estructurar unos criterios generales para considerar nuevas prácticas pedagógicas en la escuela, delimitados bajo la afirmación educar en el acontecimiento.

Si bien este tipo de aproximación a la educación no hace parte de tradiciones pedagógicas propiamente dichas, la incorporación del acontecimiento tiene un propósito central: partir de las subjetividades de las infancias contemporáneas para construir las bases de otras educaciones y otras pedagogías. Con el recorrido adelantado y el levantamiento del mapa de la subjetividad de los niños y niñas que participaron de este estudio, se propuso una triada que puede convertirse en una contribución modesta a los actuales desafíos de la educación en el tiempo presente. Se trata de la educación convergente, la pedagogía de la presencia y las hipermediaciones pedagógicas.

Para guiar la lectura del informe, es importante tener en cuenta que el trabajo fue estructurado por apartados y capítulos. Los apartados son tres: Mutación comunicacional; Mutaciones de la subjetividad; y Otras educaciones y pedagogías. Cada apartado está constituido por capítulos que presentan el objeto de la mutación, en diálogo con referentes teóricos y metodológicos, así como los resultados detallados de la indagación correspondiente.

La primera parte, denominada Mutación comunicacional, expone las principales manifestaciones de las experiencias de los niños y niñas en la comunicación digital interactiva (CDI). El apartado contiene un capítulo titulado Nuevas formas de razonamiento en la comunicación digital interactiva, en el que se presentan los hallazgos de la interacción online (red social Facebook) con los niños y niñas, para dar cuenta de la relación entre las prácticas comunicativas (en el contexto de la comunicación digital interactiva) y la producción de formas simbólicas, apelando a las categorías lenguajes y saberes. Apoyado en estos hallazgos, se problematizan las prácticas y las formas simbólicas para llegar al descubrimiento de nuevas formas de razonamiento y saberes que surgen de estas experiencias. 
La segunda parte se apoya en el capítulo titulado Subjetividades hipermediales e interactivas, el cual tiene un triple propósito. En primer lugar, busca recuperar las consideraciones, problematizaciones y hallazgos de la primera parte, en clave de subjetividad. En segundo lugar, devela las expresiones de las subjetividades de los niños y niñas que participaron del estudio. $\mathrm{Y}$ en tercer lugar, aborda algunos debates y perspectivas sustentados en las manifestaciones de las subjetividades exploradas, para interpelar las instituciones de protección de la infancia y proponer perspectivas para otras educaciones y pedagogías posibles.

Finalmente, el apartado tres, se basa en un capítulo denominado Educar en el acontecimiento. Se trata de una propuesta que recupera los hallazgos de las dos mutaciones estudiadas, y que descansa en tres caminos posibles: la educación convergente, la pedagogía de la presencia y las (hiper) mediaciones pedagógicas. La educación convergente se fundamenta en articulaciones estratégicas entre cultura popular, digital y escolar. También contempla vinculaciones entre aprendizaje invisible y conocimientos formales. Asimismo, incluye convergencias entre acción emocional-persuasiva y acción racionalreflexiva. El propósito de estas formas de convergencia socio-cultural es fomentar aprendizajes en contextos expandidos, co-construidos y distribuidos.

La pedagogía de la presencia se apoya en la perspectiva epistemológica conocida como cultura de la presencia (Gumbrecht, 2004) y en planteamientos relacionados con las simulaciones y la experiencia estética, desde diversos autores e investigadores. La base de la educación convergente y de la pedagogía de la presencia es la construcción de sentido a partir de los acontecimientos de la comunicación y la cultura, suceso que conduce necesariamente a la producción colectiva de conocimientos, la praxis colaborativa y la configuración de nuevas formas de pensar y crear basadas en el dialogismo y la polifonía de voces. Estos son los principios que guían las prácticas propuestas en las (hiper) mediaciones pedagógicas, explicadas al final del capítulo.

Finalmente, se presenta un apartado al que se le ha llamado epílogo. Dado que en los capítulos dos y tres se presentan las conclusiones de la investigación en diálogo con la propuesta educativa y pedagógica, no se busca reiterar sino más bien presentar algunas reflexiones finales sobre las infancias, la comunicación y la educación. También pretende exponer algunas consideraciones sobre el estudio de las infancias y sus posibilidades de configuración como campo de conocimiento. El propósito es dejar abiertos temas y problemas para futuros estudios. 
[33]

PRIMERA PARTE M UTACIÓN C OMUNICACIONAL 


\section{NuEVAS FORMAS DE RAZONAMIENTO EN LA COMUNICACIÓN DIGITAL INTERACTIVA ${ }^{16}$}

Tanto la antropología como la lingüística coinciden en identificar relaciones estrechas entre el lenguaje y los símbolos, comprendidos estos últimos como representaciones perceptibles de ideas que son acogidas colectivamente a través de convenciones sociales. En el marco de estas convenciones se fijan vínculos directos entre su significante y su denotado. Además de los grados de abstracción que pueden contener los símbolos en los grupos humanos de los que proceden o aquellos que los usan, es claro que estos no solo permiten interpretar y dotar de sentido las cosas, sino también orientar las acciones de los sujetos.

Generalmente las personas construyen instrumentos de conocimiento (no necesariamente científicos) para hacer inteligible el mundo natural, físico y social. Estos instrumentos no pretenden establecer conexiones lógicas entre el símbolo y la realidad, por ejemplo imitando el objeto o cumpliendo semánticamente la idea. Comprender cómo se hace inteligible el mundo no es un asunto sencillo para ser investigado. Se trata de un proceso de gran complejidad en el que los sujetos pueden proceder de tres maneras: diseñando gramáticas propias y acordadas que les permitan aprehender (racionalizar) el mundo; construyendo relaciones con los sujetos y objetos que habitan ese

\footnotetext{
${ }^{16}$ Con el propósito de lograr una mejor economía del lenguaje y no resultar reiterativos con la expresión, en adelante la Comunicación Digital Interactiva será enunciada mediante la sigla CDI.
} 
mundo; y estableciendo criterios para actuar en la vida social a partir de su propia conciencia.

Partiendo del símbolo como categoría seminal del lenguaje, es posible introducir el término formas simbólicas, planteado por Ernst Cassirer (2003) hace algo más de cinco décadas. Al formular esta categoría, el filósofo de origen judío señalaba que la función del lenguaje en la vida social no consistía solo en reconocer el contenido del símbolo para observar cómo este permitía la interpretación del objeto, sino en comprender el lugar de la experiencia humana y cultural en torno a la formas de éste.

Este debate trajo consigo la hipótesis del hombre como animal simbólico. Se trata de una expresión fundamental en la filosofía de las formas simbólicas y en la antropología de la cultura de Cassirer (2003). El símbolo es portador de sentido, lo que implica que las formas del símbolo están estrechamente vinculadas con la problemática antropológica. De otra parte, el símbolo (que va más allá del signo) es una propiedad inherente al hombre. El significado, entonces, evoca contenidos que, en sí mismos, no están presentes y que favorecen no solo la comprensión de algo, sino la conciencia de algo. A diferencia de otras teorías que dan por sentado que las formas simbólicas están en el inconsciente (por ejemplo Jung), Cassirer reafirma que la base de las formas simbólicas es el carácter consciente que hace posible su producción.

Este planteamiento sugiere una reflexión inicial frente al objeto de estudio en cuestión: las prácticas comunicativas en la CDI, entendidas como un repertorio de formas simbólicas en constante renovación (ligadas a la hipertextualidad, la hipermedialidad y la interactividad), hace que se constituya un yo y un nosotros distintos, que potencia sentidos, gramáticas e interacciones como posibilidad para la acción y la creación. Esto teniendo en cuenta, según Cassirer (2003), que las formas simbólicas no pretenden la percepción objetiva de las cosas con el fin de nombrarlas (lo que implicaría detenerse en sus usos) sino buscar la ley interna de sus formas. Los símbolos -como génesis del lenguaje- convertidos en formas simbólicas, cooperan en la construcción del mundo de esos objetos.

Cassirer (2003) plantea que tanto la ciencia como el mito o el arte, forman mundos de imágenes en los que no se refleja simplemente algo empíricamente dado, sino que más bien se crea algo en relación con principios autónomos y 
prácticas humanas. Estas posibilidades de razonamiento y de acción se van transformando a partir de la conformación de un sensorium en constante actividad, gracias a experiencias que se objetivan y se subjetivan en el sujeto (yo-nosotros). La CDI es un espacio fundamental de la cultura, por esta razón una investigación sobre la transformación del sujeto en un contexto socio-cultural en mutación como este, exige, dentro de su heterogeneidad, hallar ciertos rasgos comunes en los sujetos que la habitan.

Para tal efecto se propone el análisis de dos expresiones que articulan las prácticas comunicativas y los sistemas simbólicos en torno a la producción de sentido en los niños y niñas que tramitan sus vida a través de la cDi: las gramáticas de ordenación del mundo en torno a los códigos y las lexias que transitan por la CDI, así como sus relaciones con la hipermedialidad; y las interacciones consigo mismos, con los contenidos (producto de flujos y conexiones) y con los otros a través de la noción de interactividad.

\section{GRAMÁTICAS DE ORDENACIÓN: LA RACIONALIDAD HIPERMEDIAL}

El término gramáticas de ordenación del mundo es una especie de metáfora utilizada con el propósito de dar cuenta de los mecanismos de los que se valen los sujetos y grupos para coordinar sus vínculos con el mundo, otros sujetos, ciertos objetos y un complejo conjunto de relaciones. Se trata de un nivel inicial de orden pragmático de la cDI, en el que la persona reconoce las lógicas y los espacios de ocupación de cada objeto y cada sujeto en el tiempo-lugar que habita y comparte. En este nivel, el sujeto pone en funcionamiento un cierto número de operaciones de reconocimiento y ordenación para entender su lugar, lo que le permite acercarse a las composiciones socio-culturales del mundo de distintos modos. En tal sentido, surge un repertorio de formas simbólicas que median en esta actividad.

Mientras que algunos lo hacen con cierta cautela, otros se incorporan de manera más decidida. Es un proceso que generalmente se expresa en una fase inicial de usos y apropiaciones, que pone en funcionamiento formas de desciframiento del contexto, pero también ciertos recursos para reconocerse 
y reafirmarse en dicho espacio. Es una nueva manera de exponer y movilizar los sistemas culturales y sus redes de sentido. Particularmente, el sistema cultural de la CDi y el funcionamiento de la red social Facebook (en adelante $\mathrm{Fb}$ ), asumida como una de sus múltiples expresiones, muestra de manera especial cómo los sujetos que se incorporan en éste reconocen su interfaz, ordenan los contenidos de su perfil y ubican textos, imágenes y enlaces que ponen en escena una relación entre repertorio cultural, formas de objetivación de lo que circula allí y el lugar de su propio yo.

En el mundo de la CDI hay un sinnúmero de lexias que se encuentran dispersas en textos con diversas estructuras e intenciones comunicativas. Al parecer, estas lexias contienen funciones específicas de designación, esto es, mecanismos y canales de objetivación del mundo, los cuales están vehiculizados por la representación. Sin embargo, insiste Cassirer (2003, pp. 157-158), esta función de designación, comprendida como una relación lineal entre significante y significado, se convierte en un proceso consciente que va mucho más allá, una vez el sujeto se involucra como protagonista de la acción social y cultural. Se trata del paso del carácter sensible (orientado por la expresión mímica o analógica del lenguaje) a la expresión intuitiva, cuya forma de funcionamiento implica una relación entre la intuición y el fin de una acción. En este caso, toda acción se encuentra estrechamente vinculada con una meta especial y una dirección que guía el propósito ${ }^{17}$.

En primer lugar, existen composiciones en los niños y niñas que dan cuenta de un interés por participar en el juego de $\mathrm{Fb}$, dado que es una ventana para estar visibles y ser reconocidos en medio de ambientes urbanos y escolares que, en ocasiones, tienden a excluir y estigmatizar. Los perfiles de este primer nivel muestran a unos sujetos que ubican sus datos de acuerdo con las exigencias de la aplicación, comparten información con sus amigos y diligencian tests relacionados con el horóscopo, el amor y episodios simples de la vida cotidiana. Asimismo, datos de identificación, fotografías y logotipos (gifts) constituyen el espectro de una forma de reconocimiento de la interfaz y de sí mismo que no tiene mayores exigencias, pero que sí muestran la tendencia de estos sujetos a involucrarse rápidamente con la propuesta comunicativa.

\footnotetext{
${ }^{17}$ Este es un planteamiento que Cassirer (2003) utiliza recuperando las tesis de Kant en Crítica de la razón pura. Para Kant, aquellos conceptos que estén desprovistos de las intuiciones están vacíos. La imagen es producto de la capacidad empírica de la imaginación productiva, mientras que el esquema de los conceptos sensibles (como el de las figuras en el espacio) es un producto y un monograma de las formas de intuición.
} 
Danny (11 años), por ejemplo, ubica en su perfil sus datos básicos, una foto suya (retocada con fondo rosado), las imágenes de sus grupos musicales preferidos (Dragón y Caballero y Camila, entre otros), el logotipo de programas de tv (como el Chavo, Los Simpsons, ICarly y A mano limpia), una información prediseñada en la que se declara soltera y una alusión a su gusto por el fútbol (como parte de la sección Actividades e intereses). En su perfil manifiesta interés por la información suministrada a través de aplicaciones como el horóscopo y la recepción y el envío de regalos (chocolates y gorras de béisbol).

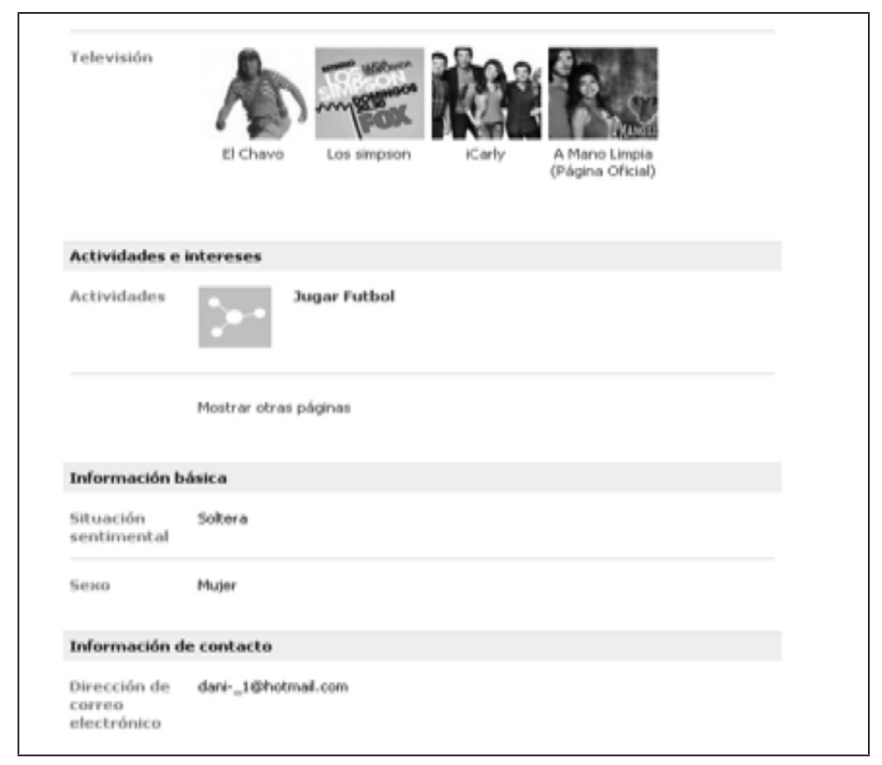

Imagen 1. Datos de perfil de Daniela

Por su parte Daniel (12 años) propone una ordenación distinta. En su imagen de perfil coloca una calavera, identifica la institución educativa en la que estudia (IED Gabriel Betancourt Mejía), se presenta como católico y ubica como inspiración de su vida la bandera del grupo Tierra Santa y una imagen alusiva al grupo musical 4 y Medio. Además, incluye dentro de sus cosas favoritas al equipo Barcelona Fútbol Club, el libro Charlie y la fábrica de chocolates, los videojuegos (online) Halo y Gears of War 2 y los programas de televisión Los Simpsons, ICarly y Bob Esponja. Dentro de sus intereses están YouTube, «pasar el año» y «no enamorarse», aunque manifiesta tener una relación sentimental vigente. 


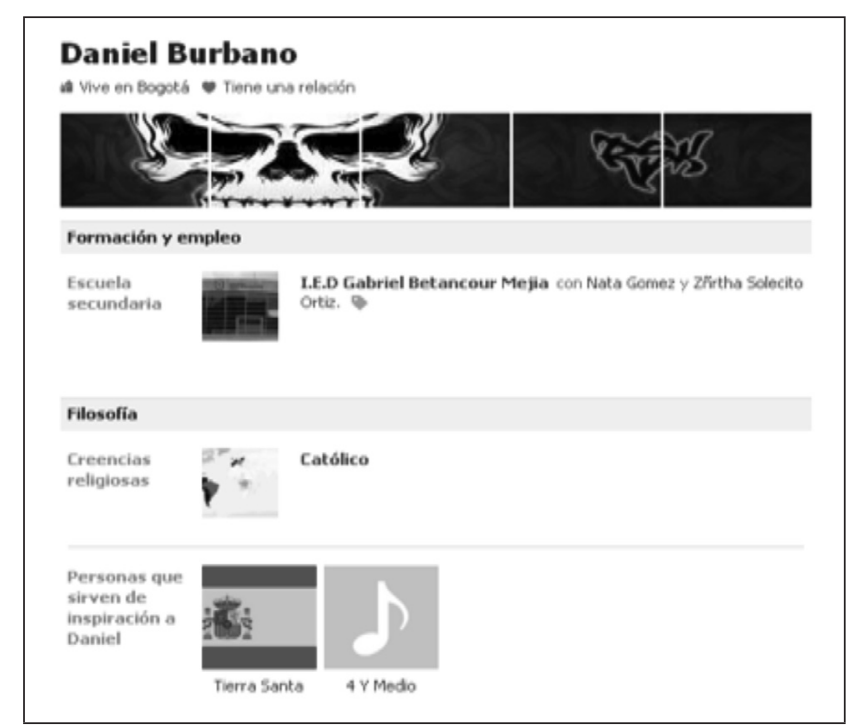

Imagen 2. Datos de perfil de Daniel

Sin embargo, existen otros niveles de ordenamiento mucho más elaborados. En este caso, las gramáticas de reconocimiento implican situar recursos que permiten construir un sello propio, expresar preferencias con cierta autoridad y propiciar espacios en la interfaz que propician el reconocimiento y la reafirmación de un modo de ser. El ejemplo lo aporta Camilo Ryu Genkay (14 años), quien, aunque también presenta su foto de perfil y datos básicos como los demás, destaca como persona que le sirve de inspiración a Kurt Cobain (grupo musical Nirvana). Exponiendo la coherencia de una estética por la que se inclina, asocia su cita favorita con este mismo artista («Es mejor ser odiado por ser como uno es, que amado por algo que no soy»). Dentro de sus equipos deportivos favoritos destaca a los Ángeles Lakers (equipo de baloncesto de la NBA de EE UU) y al Barcelona Fútbol Club (equipo de futbol de la Liga española).

Su perfil de Fb conecta a sus amigos con una cuenta de Twitter y un blog en Blogger. Intenta diseñar otros repertorios en estas aplicaciones y no repetir lo que dice y hace en $\mathrm{Fb}$. Son muchos sus enlaces a sitios; uno de los que más generó comentarios durante la investigación, es un video de la serie de TV Futurama, en la que su protagonista (Fray) expresa: «No sé si soy muy feo, o todas las mujeres creen que soy inalcanzable para ellas y no lo intentan». La escritura de frases, la incorporación de enlaces y los comentarios que promueve a través de sus expresiones son amplios y se caracterizan por dosis de ingenio, humor y una extraña reflexión de lo efímero. 


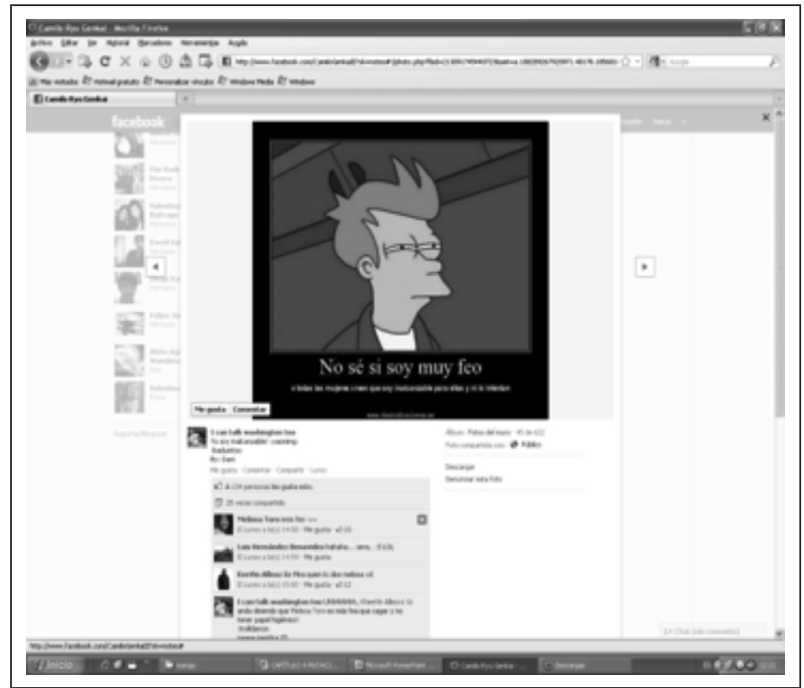

Imagen 3. Datos del muro de Camilo

La interfaz de $\mathrm{Fb}$ presenta múltiples opciones a sus usuarios. Ninguno de estos niños y niñas tomó un curso o hizo parte de un proceso de formación que le permitiera utilizar este conjunto de aplicaciones. En la práctica han incorporado recursos de orden sensible e intuitivo para incorporarse en esta propuesta comunicativa.

Aunque a simple vista existen claramente dos niveles en la ordenación de los contenidos, parece ser que estos sujetos han construido capacidades para enfrentar las diversas lógicas de funcionamiento del contexto comunicativo (el cual propone actualizaciones y cambios con cierta frecuencia), en las que suelen proceder con imitaciones, interpretaciones y producciones propias. Lo importante de estas lógicas es que favorecen la interpretación del mundo mediante la producción de microrelatos propios y la configuración de ficciones que se componen de textos escritos, imágenes, animaciones y enlaces que complementan, amplían o ejemplifican lo que están anunciando.

Esta es una evidencia del tránsito de la expresión sensible a la expresión intuitiva, al decir de Cassirer (2003). Este desplazamiento se observa en la medida en que estos sujetos pretenden fijar metas (por ejemplo comunicar un estado de ánimo), utilizar imágenes (que no siempre operan como analogía sino más bien como metáfora), ocupar un espacio (allanar el perfil y actualizarlo) y proponer trayectorias para descubrir significados (componer un collage de imágenes y/o proponer enlaces con contenidos de interés). 
Mientras que Danny y Daniel, con sus diferencias, desarrollan prácticas de ordenación de carácter imitativo y en ocasiones interpretativo, Camilo ordena su información bajo una lógica propia: compone relatos de su propia vida a partir de fragmentos de Tv, música y deportes. Cassirer (2003, p. 139) señala que los lenguajes en general (imitativos, mímicos e indicativos), constituyen una suerte de ademanes simbólicos que no necesariamente copian directamente el objeto o la actividad que ha de expresarse mediante la analogía o la mímica. Esta actividad encuentra dos operaciones posibles para la producción de significado: la designación indirecta (orientada por el principio de arbitrariedad) ${ }^{18}$; y la aprehensión del objeto mediante la incorporación de nuevas lexias y otros códigos de desciframiento.

Las formas de ordenación del mundo ejercidas por estos sujetos a través de la mediación de $\mathrm{Fb}$ están motivadas por la necesidad de situar los principales referentes y contenidos que dotan de sentido su espacio vital. Como se pudo apreciar, la actividad de estos niños y niñas en $\mathrm{Fb}$ se centra en comprender el lugar que ellos y ellas ocupan, así como sus niveles relacionales con otros sujetos, algunos objetos y ciertos fenómenos socio-culturales que en su momento rodean y componen este contexto comunicativo.

La interfaz de $\mathrm{Fb}$ es un espacio que ha sido apropiado por estos niños y niñas y que opera como mediación para producir los sistemas simbólicos que les posibilitan la producción de sentido. Los usos y apropiaciones de la información y de las aplicaciones que circulan en $\mathrm{Fb}$ favorecen la cristalización de un repertorio sustantivo de contenidos y referentes de la cultura, que les provee capacidades para implementar ejercicios de permanente desciframiento y vinculación con otros sujetos y grupos.

En este caso, proponer una ordenación que incluye el uso de una serie de recursos gráficos en relación con la propia vida, es un acontecimiento que encuentra en el lenguaje no solo un medio de expresión, sino una mediación para anudar los contenidos del mundo y los contenidos de la propia existencia.

El uso y la apropiación de este entorno termina develando formas de desciframiento del yo que se vuelven fundamentales para estar vigentes en un

\footnotetext{
${ }^{18}$ En la perspectiva de Saussure (2002), la relación significado-significante está mediada por el signo, que es arbitrario. Mientras que la cosa (el objeto) designa el significante, el componente mental (organizado a través del signo) designa el significado. El signo lingüístico es arbitrario en la medida en que la conexión entre significante y significado no se basa en una relación causal.
} 
contexto de visibilidad, en el que se requiere cierto ingenio. Por ejemplo, las personas que inspiran a Valeria (14 años) en su perfil dan cuenta de ese nexo entre un formato de contenidos gráficos que están dispersos (en sitios Web, blogs y Wikipedia), pero que termina ordenando con cierta lógica:

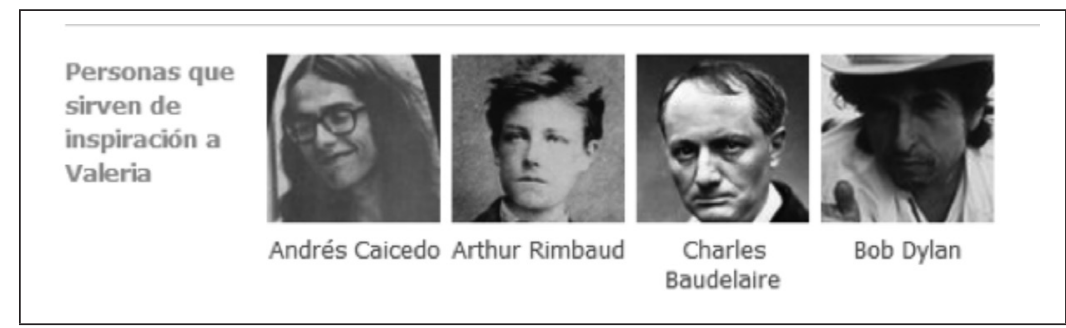

Imagen 4. Datos del perfil de Valeria

Al parecer, la literatura y la música constituyen un eje central en la vida de Valeria. Seguramente Baudelaire y Rimbaud hacen parte de un estilo que ha descubierto por algún motivo (poetas malditos, literatura francesa, romanticismo...) y que le genera algunos vínculos con Andrés Caicedo, un escritor colombiano que murió muy joven y que se ha convertido en un referente para cierto público en Colombia. Por su parte, la alusión a Bob Dylan es el nexo entre la escritura y la música, pues es el ícono de un estilo que incomodó por sus letras, pero que inspiró a muchos en la conformación de un género arriesgado, acelerado y generador de emociones de diverso orden: el rock.

Lo que se observa en las experiencias de estos niños y niñas es que transitan de la simple ordenación de contenidos y aplicaciones que les provee la interfaz a un conjunto de gramáticas de racionalización en las que se involucran de distintos modos. Para tal efecto el uso de frases, la escritura de ciertas expresiones cargadas de metáforas y la descripción de eventos de la vida cotidiana, dan cuenta de la emergencia de habilidades comunicativas que van más allá de la escritura lineal y el texto escrito.

Se trata de una racionalidad hipermedial que opera preferiblemente de dos maneras: en la composición de collage de imágenes prediseñadas (por ejemplo de actores o cantantes) e imágenes de sus redes de amigos y familiares; y combinando textos, imágenes y enlaces de música y videos. En ambos casos los niños y niñas están implicados como testigos de un acontecimiento, como sujetos que desean expresar emociones y/o como protagonistas de actos creativos. 
La existencia de un conjunto de gramáticas de ordenación del contexto comunicativo de $\mathrm{Fb}$ implica destacar también los esfuerzos de estos sujetos por componer cierto performance en sus prácticas comunicativas. Estas producciones proceden de piezas dispersas que están contenidas en diversas fuentes de la Web 2.o, pero que también han sido originadas en las múltiples narrativas de su vida cotidiana, las cuales están frecuentemente cargadas de vivencias y emociones (por ejemplo en las fotografías que registran acerca de acontecimientos de su vida familiar, escolar y de amigos). Estas prácticas traen consigo una nueva racionalidad: la racionalidad hipermedial.

Esta racionalidad procede del conjunto de expresiones sensibles e intuitivas que han sido originadas por las formas simbólicas que se alojan en la CDI. De este modo, la contaminación entre medios, contenidos, narrativas y sujetos hace que estos niños y niñas deban proceder (como usuarios-prosumidores de la CDI) con algún tipo de ordenación que les permita apropiar los elementos de la interfaz y hacer inteligible el contexto comunicativo y sus opciones de reproducción o deconstrucción.

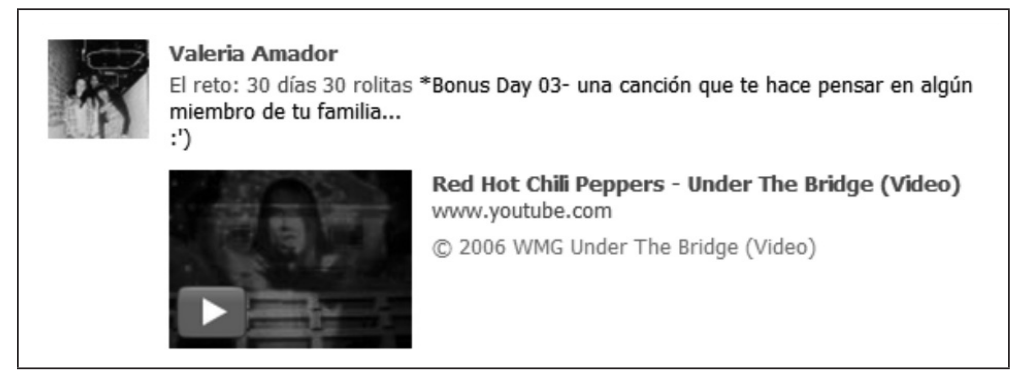

Imagen 5. Datos del muro de Valeria

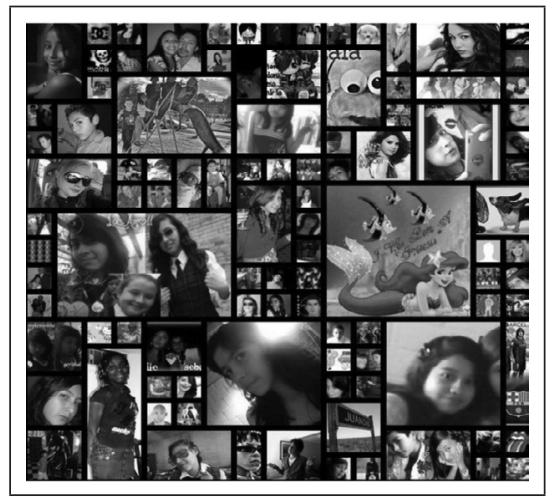

Imagen 6. Datos del muro de Dany 
Este suceso implicaría admitir la existencia de una pragmática de la comunicación digital interactiva (ciberpragmática) ${ }^{19}$, capaz de objetivar el mundo mediante experiencias estético-comunicativas. La objetivación, en este caso, opera de otro modo, esto es, como una racionalización de la vida que no se agota en la designación analógica de los objetos sino en una esfera de la producción de sentido que contiene, cada vez, mayores fuentes que intervienen en su representación.

Sin embargo, también es posible admitir que la designación indirecta de los objetos implica algo que va más allá de un intento de objetivación: usar y apropiar lenguajes para producir nuevos sentidos. En este caso la ubicación de iconografías (para producir un collage como lo hace Dany), así como la incorporación de enlaces para acceder a otros sitios (blogs, otra red social, videos y música), da cuenta de racionalidades hipermediales que permiten producir experiencias estéticas a partir de fragmentos, partes y puzzles.

Esto da lugar a convertir el entorno en una especie de rompecabezas, cuya forma de funcionamiento implica la interacción entre autores, público, seguidores y opositores. Al parecer, una de sus principales características es la puesta en escena de la obra de la vida de un sujeto, quien ubica textos e intertextualidades en un espacio (en este caso $\mathrm{Fb}$ ) para provocar su desciframiento.

Scolari (2008) analiza la hipermedia como una propuesta que, además de introducir nuevos géneros y posibilidades distintas de participación sobre la obra, constituye un escenario propenso a la generación de formas sensibles o estéticas. Este proceso implica la remodelación de los lenguajes de los viejos medios con las expresiones de otras tecnologías y medios (mediante transmediaciones y convergencias) y una alta dosis de articulación entre texto escrito, imágenes, videos, filmes, entre otras producciones que actualmente circulan por las pantallas en la CDI.

Basados en estos hallazgos iniciales, se puede afirmar que la racionalidad hipermedial se construye mediante un conjunto de propuestas viso-perceptuales, estéticas y cognitivas que favorecen la producción de sentido, en términos de ordenación de sujetos, objetos y fenómenos del mundo social,

${ }^{19}$ Basados en Isabel Sánchez (20II) y Francisco Yus (200I), se puede afirmar que la ciberpragmática implica usos variados del lenguajes en entornos de comunicación virtual. Es una perspectiva que parte de la categoría convencional pragmática, pero que se actualiza bajo las nuevas formas de comunicación que trae consigo el repertorio tecnológico contemporáneo. 
mediados por la composición de textualidades e intertextualidades en las que convergen lo escrito, la imagen fija y las imágenes en movimiento a través de lo digital.

Este tipo de racionalidad es distinta a la racionalidad hipotético-deductiva, analógica y dicotómica (bifurcación sujeto-objeto) propia del logocentrismo de occidente. Su principal modo de funcionamiento implica la articulación de formas de presencia entre el sujeto y el mundo a través de un espacio (CDI), que favorece tanto la expresión sensible como la intuitiva de las formas simbólicas.

El sujeto, portador de esta racionalidad hipermedial, ocupa un lugar en ese espacio y desde allí promueve acciones con diversas arquitecturas de estructuración e interacción. Una de ellas es el uso básico de las aplicaciones que le provee una interfaz como $\mathrm{Fb}$, acción que aunque revista simplicidad, contiene potencialidades para la intertextualidad. La otra implica el conjunto de procesos, asociados con la expresión sensible, enunciados hasta el momento: una composición de lenguajes que permite aprehender el sí mismo en la contrafigura de la acción hipermedial.

\section{RACIONALIDAD INTERACTIVA Y ARQUITECTURAS DE PARTICIPACIÓN}

Además de las gramáticas de reconocimiento del sí mismo en el espacio de la CDI, comprendidas como el esfuerzo de los sujetos por objetivar el mundo mediante repertorios simbólicos, orientados por la expresión intuitiva, existe otra esfera de este fenómeno que es fundamental para comprender la relación prácticas comunicativas-formas simbólicas: la interactividad. Este proceso es un eje constitutivo de las nuevas formas de comunicación y ha sido uno de los objetos de estudio de mayor desarrollo durante los últimos diez años. Considerar la existencia de las hipermediaciones es aceptar de entrada a la interactividad como centro de su configuración y despliegue.

Por ahora, lo más importante es comprender las formas de funcionamiento de la interactividad que se producen en las prácticas comunicativas de estos niños y niñas. El análisis muestra que es posible aceptar la emergencia de una racionalidad interactiva, que no solo implica objetivar el mundo, sino crear vínculos con otros para dilucidarlo y hasta deconstruirlo. También 
es necesario señalar, por lo observado en este ejercicio analítico, que las prácticas comunicativas de estos sujetos se constituyen en un escenario con importantes potencialidades para fomentar una nueva cultura de la participación. Aunque es claro que la Web 2.0 -en particular $\mathrm{Fb}$ - ha sido un espacio utilizado en ocasiones para agredir y promover acciones violentas, los niños y niñas que participaron en el estudio muestran que es posible usar y apropiar esta hipermediación con otros propósitos.

La interactividad es un proceso de vinculación que se da entre personas a través de medios y mediaciones, lo que implica dinamismo, movimiento y cambio. En el modelo emisor-receptor-broadcasting, el vínculo a través de los medios generalmente se daba a través de la relación uno-muchos. En este modelo, las posibilidades de participación eran mínimas y sus contenidos se supeditaban a la imposición de un autor, quien fungía como el administrador de una audiencia o la parte activa de un proceso de recepción, orientado hacia las masas.

Como se señaló anteriormente, el posicionamiento de los usuarios como gestores de un espacio (por ejemplo Fb, un blog, un fotolog o una Wiki) y protagonistas del proceso de producción de formas simbólicas que circulan por las interfaces de la cDI, ha replanteado este viejo modelo. Por consiguiente, en este orden de ideas, una vez los sujetos se sitúan en ese espacio y lo colonizan, se inicia algo que va más allá de la recepción y el consumo de contenidos. Se trata de formas de interactividad que pueden llegar a construir una nueva racionalidad, así como nuevas arquitecturas de participación ${ }^{20}$.

Existen tres circunstancias que son propias de la CDI y que permiten entender la potencia de la interactividad: una, la circulación de contenidos como un suceso en el que la información fluye sin censuras y que puede ser usada o apropiada por alguien (en el caso de los niños y niñas de este estudio, la información frecuentemente se centra en videos, música, mensajes de Messenger, fotografías y enlaces a videojuegos y ovas); dos, el intercambio de contenidos con fines específicos (mostrar temas de interés general, compartir asuntos comunes de un grupo, cumplir con desafíos grupales); y

${ }^{20}$ El planteamiento sobre arquitecturas de participación en Piscitelli (2009, p. 244) se basa en la tendencia contemporánea relacionada con comunidades de producción par a par. Estas pueden llegar a ser exitosas siempre y cuando el proyecto que adelanten sea modular (que se pueda dividir en tareas más pequeñas); granular (que las tareas sean sencillas y realizables); e integrativo (que el trabajo de las partes se pueda juntar y coordinar alrededor de un resultado final visible). 
tres, intervenir los contenidos mediante aplicaciones y dispositivos libres que favorecen la colaboración y la creación colectiva.

El análisis realizado permite identificar tres grandes dimensiones de la interactividad en estos niños y niñas: la producción de interactividades mediadas por distintos vínculos entre el yo y el nosotros, cuyo trama central es la emoción y la provocación; la composición de interactividades que operan en las fronteras del deber ser-hacer y el ocio; y un conjunto de interactividades que facilitan la participación dada su naturaleza abierta y reticular.

En relación con la primera dimensión (interactividades mediadas por el yo y el nosotros), el análisis permite identificar tres elementos centrales: las emociones, los intercambios y las reacciones. En los tres casos se puede dilucidar la interactividad del sujeto consigo mismo y su intención de implicar a otros, lo que conduce a la incorporación de una serie de narrativas que dan cuenta de estados de ánimo (en ocasiones muy variables), capaces de propiciar una suerte de monólogos o soliloquios que son visibles para sus espectadores y contactos. Este interés por producir un testimonio de sí mismo no siempre pretende exhibir la intimidad, también busca reafirmaciones y provocaciones para que otros se impliquen o reaccionen. Tal vez, como solución a su problema.

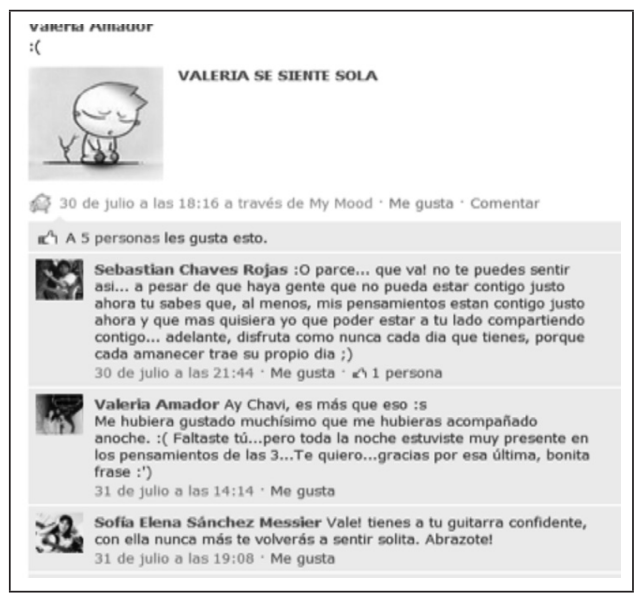

Imagen 7. Datos del muro de Valeria

Por ejemplo, ante un estado de ánimo -ilustrado por una imagen (prediseñada) - de soledad y melancolía, los amigos de Valeria reaccionan expresando 
su apoyo y «compañía». La recomendación de Sebastián podría parecer el lugar común de cualquier persona que intenta consolar a un amigo. Sin embargo, expresa que sus pensamientos están con ella y que debe disfrutar el día, acentuando el presente y el aprovechamiento del aquí y el ahora. Más allá de la circulación de una representación, Sebastián propone un ejercicio de producción de presencia: «(...) mis pensamientos están contigo justo ahora».

Por su parte Sofía (su profesora de guitarra, mujer adulta) le propone acudir a su guitarra, pues puede ser una compañía ideal para superar esta sensación de vacío que implica su expresión en tercera persona «Valeria se siente sola». Es un objeto que puede subjetivizarse, según lo sugiere Sofía, pues ésta puede comportarse como su confidente y ayudarle en medio de su aflicción. Como se observa, las emociones pueden ser tramitadas individual y colectivamente a través de la cDI y se constituyen en un registro de la subjetividad que es resuelto mediante formas de interactividad que van del yo a los otros y a la inversa.

Las emociones son centrales en la vida de los niños y niñas. Estas observaciones muestran que $\mathrm{Fb}$ se convierte en una opción no solo para expresar y manifestar emociones y deseos, sino también para encontrar posibilidades de consuelo y valoraciones que contribuyan a una especie de reparación existencial. Este tipo de interactividad es generadora de vínculos y solidaridades, dado que puede llegar a convertirse en un dispositivo para tramitar las emociones.

Tempranamente, hacia el siglo xvII, el filósofo Baruc Spinoza se refirió al problema de los vínculos entre los seres humanos, al señalar que estos no son simplemente términos o declaraciones que garanticen su efectuación. Al parecer, los vínculos son relaciones que se tejen alrededor de la singularidad, esto es, como un fundamento y una sustancia que proviene de la naturaleza. De allí que sea posible su eternidad ${ }^{21}$. El fomento del vínculo, entonces, no es

\footnotetext{
${ }^{21}$ En su Ética demostrada según el orden geométrico, Spinoza se refiere a Dios, al ser humano y al lugar que el hombre ocupa en la naturaleza. Plantea que la forma adecuada de entender a los hombres es situarlos como una parte más de la naturaleza y que las acciones humanas no se deben analizar con criterios morales, sino como partes necesarias de las leyes que rigen el cosmos. Asimismo, asegura que los valores son creaciones humanas arbitrarias y que las emociones están ubicadas entre la naturaleza y las convenciones humanas.
} 
una simple contemplación sino algo que acontece y que contiene rasgos de potencia, si logra pasar de la expresión a la efectuación.

La producción de interactividades en las que el sujeto reafirma una forma de pensar y sentir es fundamental en la construcción de lo colectivo. Esto si se tiene en cuenta que los proyectos colectivos no implican la uniformidad y la homogeneidad. Mauricio Lazzarato (2006) señala al respecto que las emociones son la base del acontecimiento y el insumo fundamental para la efectuación de lo posible. Los niños y niñas que han ingresado en esta atmosfera de la expresión y la emoción, ratifican que el componente afectivo es una dimensión necesaria en sus vidas. De este modo se tejen conquistas de escenarios interactivos, prácticas potenciadoras de vínculos tendientes a la solidaridad, pero también, en algunos casos, prácticas de confesión surgidas de la interactividad entre el yo y el nosotros, como lo ratifica el mensaje de Daniel.

Daniel (12 años), por ejemplo, publica en su perfil la letra de una canción que le permite expresar una decepción amorosa. Aunque no emplea expresiones directas para referir al tema o a la persona implicada, busca que sus contactos conozcan sus emociones mediante un texto escrito.

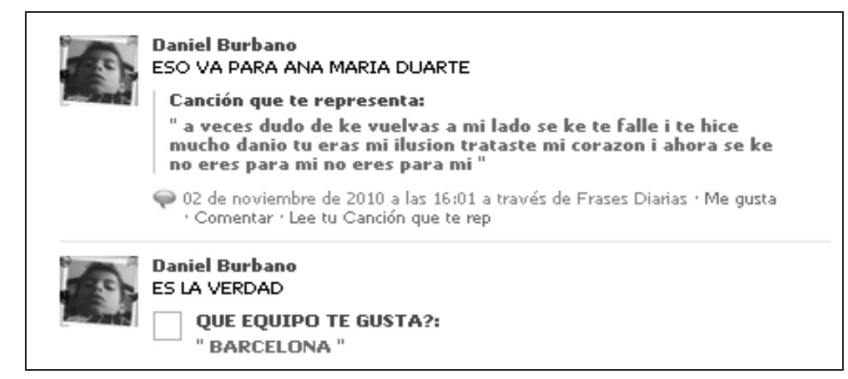

Imagen 8. Datos del muro de Daniel

Otro de los aspectos llamativos de esta forma de interactividad es la provocación. No siempre buscan la solidaridad, sino también reacciones a temas que pueden ser polémicos y que pasan por preferencias y gustos. Al respecto, los géneros musicales constituyen uno de esos temas que siempre produce dimisiones y adscripciones. El ejemplo lo otorga Camilo Ryu Genkay al referirse a la banda sonora de un filme: 


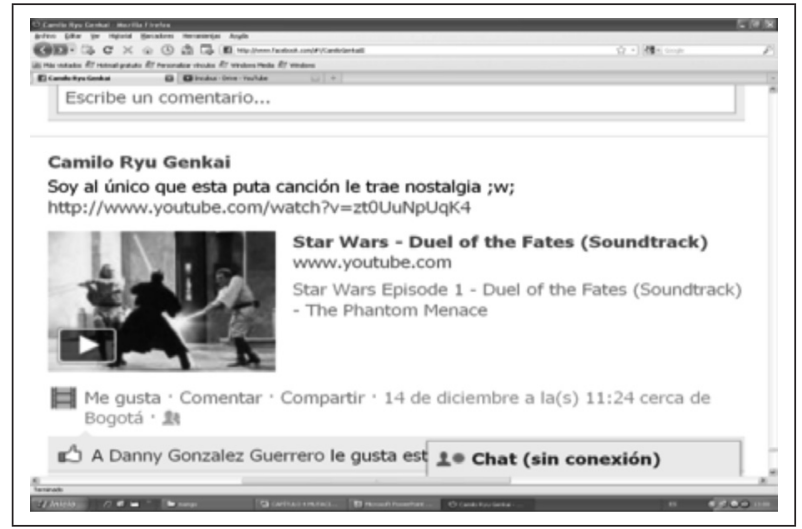

Imagen 9. Datos del muro de Camilo

En este caso, Camilo hace casi un monólogo en el que trae a colación uno de los temas musicales del filme Star Wars (Duel of the Fates). El enlace ubicado en su perfil le trae una evocación simple, pero llena de nostalgia. Al parecer, Camilo fue un gran seguidor de la saga y se siente afectado porque, según su expresión, es el único al que le genera nostalgia. Es evidente que Camilo quiso provocar algún nivel de controversia (o una remota solidaridad) a través de su comentario y la composición que propuso mediante el uso del enlace sobre el tema.

Se trata también de una forma de producción de presencia «pensando y sintiendo en voz alta». Tanto Camilo como la mayoría de los niños y niñas del estudio expresan emociones y deseos, una necesidad de decir lo que piensan y sienten in situ, esperando que sus interlocutores respondan. Como se puede apreciar, la CDI no es solo un canal de expresión por donde circulan textos y aclamaciones escritas. Es una mediación que hace posible el flujo de palabras y conexiones permanentemente para lograr ser leídos (escuchados), pues casi siempre hay alguien que reacciona. Aunque una de sus amigas (Danny González) intervino sin problematizar la provocación de Camilo, marcó la expresión «A Danny González le gusta esto».

El segundo nivel de interactividades está relacionado con un conjunto de prácticas, intercambios e hibridaciones que son producidas en una zona gris entre deber ser-hacer y ocio. Aunque este es un tema mucho más frecuente en poblaciones de adultos como los profesionales (Igarza, 2009), este grupo de niños y niñas muestra que el espacio de la cDI admite estas dos figuraciones y que no se oponen o generan tensión. Sin embargo, es importante problematizar 
el planteamiento de Igarza sobre la dicotomía productividad-ocio, en la medida en que la interactividad contiene potencialidades para la productividad, no en el sentido de una actividad laboral sino en términos de la potencia que este proceso trae consigo.

Para el investigador argentino una de las expresiones más destacables del entorno mediático y comunicacional del siglo xxI es la generación de brevedades en espacios e intersticios de ocio y de productividad. Adicionalmente, con la recepción móvil, se favorece la producción de micro-cápsulas de tiempo para la fruición y el entretenimiento compartidos. Confirma Igarza (2009, p. 12) que, para las generaciones jóvenes (nativos digitales), la comunicación interpersonal y el entretenimiento se conjugan simultáneamente. Sus vidas constituyen secuencias permanentes entre brevedades e intermitencias de todo tipo.

En este caso, los niños y niñas del estudio utilizan la Web 2.o (Fb) como un espacio de entretenimiento permanente. En realidad, sus prácticas no están vinculadas a la productividad económica ni a resolver tareas de orden laboral. En términos de Igarza, lo que predomina en estos sujetos sería el ocio. Sin embargo se trata de un ambiente en el que lo efímero y lo sensible constituyen una forma de existir y de vincularse a un espacio en el que participan varios sujetos y grupos mediante desafíos permanentes. Uno de esos desafíos lo propone Maka (13 años), quien, en medio de los temas cotidianos de Fb, introduce contenidos alusivos a lo escolar.

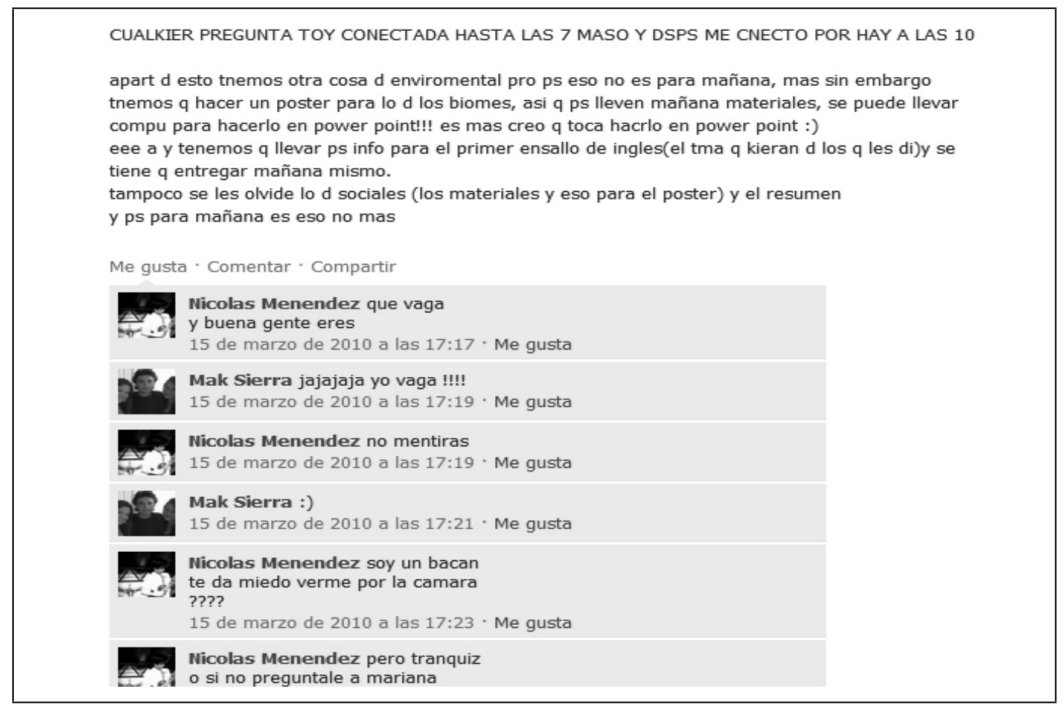

Imagen 10. Datos del muro de Maka 
La escritura del texto es una apuesta pragmática que da cuenta de algo que se está conversando mediante $\mathrm{Fb}$ en torno a obligaciones académicas. No se trata de un texto formal de carácter informativo que pretenda exponer las actividades que deben cumplir los estudiantes para el día siguiente. La alusión a «cualkier pregunta toy conectada hasta las 7 maso y dsps me cnecto por hay a las 10» es una expresión paradójica en la que lo oral está en lo escrito. La composición de la frase a través de lexias como «toy» $\mathrm{y}$ «maso», introduce un tono de conversación y un esfuerzo por ser fiel a un estilo narrativo que opera en su vida cotidiana.

De otra parte, llama la atención cómo en un pequeño párrafo sintetiza todo lo que sus compañeros deben hacer para el día siguiente. Además de precisar la tarea que deben efectuar (hacer un poster), les indica los recursos que deben llevar y hasta les hace recomendaciones acerca del tema sobre el ensayo para la asignatura de inglés (recordando que previamente les había sugerido unos temas). Uno de sus compañeros, Nicolás, le agradece y con cierta ironía le dice: «que vaga y buena gente eres». La ironía es corroborada por Maka cuando en el acto le replica «jajajaja yo vaga !!!!».

Esta forma de interactividad corrobora algunas características que autores mencionados anteriormente han señalado a propósito del apelativo «nativos digitales». En primer lugar, sus niveles de interactividad están mediados por este conjunto de pragmáticas, en las que las lexias (letras, símbolos, dibujos, imágenes, emoticones) componen textos polifuncionales, esto es, textos que informan, expresan, dialogan, narran, denuncian y crean. En tal sentido, la oralidad vehiculizada por el texto, encuentra en lo digital una posibilidad de acción in situ que logra objetivos como el de Maka (recordarle a sus compañeros sus compromisos académicos). La respuesta de Nicolás da cuenta de esta pragmática.

Es importante reconocer además que no siempre los temas de conversación en $\mathrm{Fb}$ son vacíos o resultan improductivos. Al parecer, Maka reparte sus tiempos entre conversaciones y preocupaciones académicas. Por esta razón, aprovecha el medio para hablar del deber ser-hacer y ser útil a sus compañeros, quienes probablemente están conectados pero no muy pendientes de sus compromisos académicos. Este tema abre un abanico de inquietudes sobre la distribución de los tiempos para lo escolar y para «sus temas» en la Web 2.0, las iniciativas académicas que pueden ser fomentadas a través de esta mediación, así como el manejo de los intersticios entre esos dos niveles. 
Aunque aún no es tiempo de introducir el problema educativo de la cDi y de las infancias contemporáneas, se puede anticipar que no se trata de utilizar el medio para replicar las prácticas escolares. Lo que hace Maka, en su propia narrativa, es introducir un tema útil para los que están conectados y que, en este caso, estarían en el intersticio del «ocio» y la «productividad». En realidad estos tiempos se entremezclan y redefinen permanentemente. El desvanecimiento de estas dos formas de ver el mundo como opuestas, sería un punto de partida para reconocer su potencialidad. Es una frontera que debe ser revisada (Rodríguez, 2011). Seguramente, familia y escuela son los primeros que deben revalorar esta dicotomía.

Finalmente se encuentran las interactividades afines a la participación. Estas son mucho más complejas en la medida en que implican la puesta en escena de acciones colectivas, la producción de procesos creativos y la generación de obras construidas en la lógica de comunidades. En términos más cercanos a la CDI, implica fomentar las condiciones necesarias para hacer posible la comunicación cooperativa y descentralizada (Scolari, 2008, p. 193). Una interactividad de orden participativo no le apunta a productos que se puedan vender, según la lógica del mercado. Lo que busca la interactividad participativa es la generación y distribución de contenidos útiles para la vida en comunidad.

Piscitelli (2009) ha propuesto al respecto el término arquitecturas de participación. Aunque resulta un enunciado complejo, especialmente por las implicaciones ético-políticas que este debate acarrea en la actualidad, es importante destacar que aquello que está aconteciendo con estos niños y niñas en la CDI contiene un conjunto significativo de prácticas de gran potencialidad para los grandes desafíos que adquiere todo aquello que engloba el neologismo Procomún.

Lo Procomún consiste en la constitución de un entorno en el que los sujetos y grupos pueden producir información y cultura acorde con sus propios intereses: «(...) Favorece un desarrollo expansivo tanto para la producción no orientada al mercado, como para la producción radicalmente descentralizada» (Piscitelli, 2009, p. 251) 22. El término arquitecturas, una vez más orienta la discusión hacia los espacios y las formas. En este caso, la interactividad

22 Las aproximaciones que sugieren Piscitelli y otros autores para abordar las posibilidades de participación y creación colectiva en la Web, suelen estar asociadas con el movimiento Cultura Libre (Lessig, 2004), Creative Commons y Softwre libre (Stallman, 2003). 
como opción de acción colectiva supone la existencia de espacios libres y sin restricciones, atributos de los que deberían estar dotados todos los espacios culturales y simbólicos de la vida cotidiana de las personas.

Las exigencias de este nivel de interactividad (en términos de lenguajes, saberes y procesos creativos) son altas, dado que implica participar de proyectos en comunidad. Es evidente que ninguno de los niños involucrados en y niñas de este estudio participa en comunidades de práctica o se ha vinculado a creaciones colectivas en el marco del diseño, el digital art o grupos de aprendizaje online. Sin embargo, las prácticas comunicativas analizadas contienen algunas aproximaciones interesantes a los atributos de las arquitecturas de participación. Una de estas aproximaciones corresponde al uso de información, por parte de Valeria, de un movimiento social de jóvenes (Movimiento Rock Ciudad Bolívar) para provocar reacciones en $\mathrm{Fb}$. Al respecto, plantea: «Que el rock no muera y que su legado sea la lucha... esperemos que así sea...».

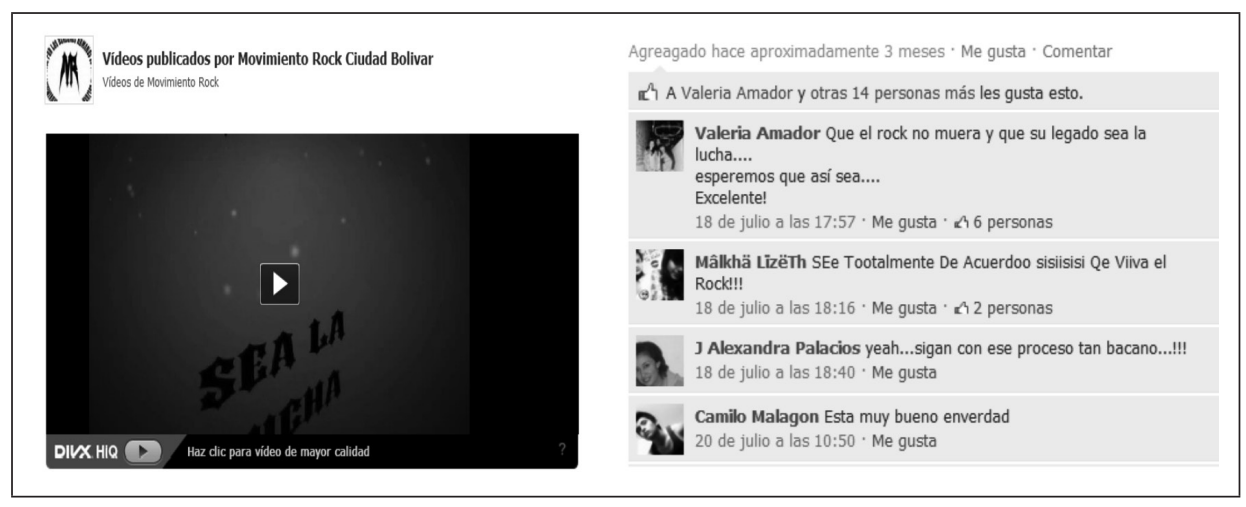

Imagen 11. Datos del muro de Valeria

Utilizando la información de un grupo de $\mathrm{Fb}$ (Movimiento Rock Ciudad Bolívar) y mediante el enlace de un video ubicado en YouTube, Valeria propone mediante una simple frase tres cosas que provocan participación y deseos de volverse parte de la propuesta o, al menos, de expresar su adhesión: que el rock siga vigente, lo que implica un compromiso de sus seguidores y conocedores para mantener el legado; efectuar una lucha que trascienda su carácter estético, asunto que invita a considerar su fuerza política y su condición de dispositivo para la acción social; y una consigna que desafía a sus interlocutores a través de la expresión «... esperemos que así sea», lo que supone invitar al compromiso colectivo de los implicados. 
Aunque no se trata de las acciones que emplearía una comunidad de práctica, existe en este esfuerzo un conjunto de iniciativas con potencialidades para la creación colectiva. El ejemplo lo otorga el conjunto de reacciones que provocó Valeria en los niños y niñas de su misma edad: «see totalmente de acuerdoo sisisisi qe Viva el Rock!!!»; «yeah...sigan con ese proceso tan bacano...!!!»; «está muy bueno enverdad». Aunque son simples frases de aprobación, estar de acuerdo y valorar la gestión de un grupo que articula rock y política en una localidad como Ciudad Bolívar en Bogotá, plantea a la CDI y a $\mathrm{Fb}$ como opción para favorecer entornos reflexivos (Brea, 2007). Reflexividad que convoca y que puede llegar a comprometer a sus participantes.

Señala José Luis Brea (2007, pp. 74-75) que en estas formas de comunicación interactiva e hipermedial existen tres cualidades que la definen como entornos proclives a constituir comunidades de participación. En primer lugar, son entornos capaces de generar resonancia colectiva, cuyos receptores (en otrora) no son incorporados como masa enmudecida, sometidos al efectismo y la espectacularidad, sino convocados de acuerdo con la organización de su propio tiempo de recepción y disponiendo las condiciones reflexivas y críticas para su incorporación en la propuesta comunicativa.

$\mathrm{Su}$ segunda cualidad está relacionada con el carácter bidireccional y multi-trayectoria que adquiere la comunicación interactiva, fenómeno que está asociado con el carácter DIY media (Do It Youself) ${ }^{23}$, el cual fomenta en ciertos públicos (como los niños, niñas y jóvenes) deseos permanentes de exploración y vinculación. En tercer lugar, en la comunicación interactiva e hipermedial existen posibilidades para la construcción de la autonomía, en la medida en que existen sujetos que pueden tomar la información de su interés y convertirla en objeto de "programación», esto es, seleccionar lo que les llama la atención y favorecer acciones colectivas (como adhesiones, debates, críticas, conflictos). El espectador programa el flujo de información que le interesa.

${ }^{23}$ Es un planteamiento de Brea (2007, p. 74) en relación con el lema: «Hágalo usted mismo». Al respecto, agrega «(...) Se trataría de establecer la singularidad de Internet como tecnología de comunicación, para hacer en su entorno más pensable que nunca lo ha sido esa aspiración a desarrollar comunidades de participación -entornos en que todos los participantes en los juegos de habla y comunicación pudieran serlo al mismo título, en las mismas condiciones: contextos de acción comunicativa en los que la separación jerárquica y verticalizada de emisores y receptores deje definitivamente paso al rizoma horizontal y acéntrico de una multiplicidad dispersa de utilizadores-»l. 
En términos generales, las tipologías de interactividad identificadas en esta pesquisa muestran la constitución de racionalidades interactivas en el mundo de las hipermediaciones. Al parecer, la incorporación de estos niños y niñas a interfaces que posibilitan la producción de interactividades mediadas por distintos vínculos entre el yo y el nosotros (cuyos ejes descansan en la emoción y la provocación), por las fronteras del deber ser-hacer y el ocio, así como aquellas que estimulan la participación dado el carácter abierto (DIY) y reticular de la CDI, fomentan otros modos de pensar, decir y actuar. Aunque es claro que esta ruta no siempre es el orden de la racionalidad interactiva, las prácticas de estos niños y niñas muestran diversos órdenes en los intersticios de esta forma de racionalidad:

- Decir cosas (a través de escrituras hipertextuales in situ) para exhibir y así encontrar respuestas simples, como aprobaciones y adhesiones.

- Expresar sentimientos y emociones para buscar apoyos y solidaridades.

- Expresar ideas y puntos de vista para hacer reflexionar a otros, promoviendo reacciones, diálogos, controversias y conflictos.

- Hacer composiciones visuales, hipertextuales e hipermediales para invitar a pensar a otros, quienes pueden involucrarse con la propuesta a través de otras escrituras y creaciones que visibilizan percepciones, ideas y reflexiones.

De este modo, apoyados en Lévy (2007) y Casacuberta (2003), se puede señalar que la racionalidad interactiva es un modo de pensamiento en el que los sujetos hacen inteligible el sí mismo, el otro y el mundo, mediante vínculos que son producidos en mundos de flujos y conexiones. En estos entornos (construidos a partir de nodos y enlaces en constante movimiento) se desarrollan dos operaciones fundamentales: la exploración que los sujetos hacen de las formas simbólicas que invaden permanentemente este espacio; y la actualización de dichas formas simbólicas mediante la penetración y recomposición de los contenidos que circulan por las interfaces de la CDI. Para Lévy (2007, p. 61), una vez las interacciones adquieren el poder de enriquecer o de modificar el modelo, el mundo virtual se convierte en un vector de inteligencia y de creación colectiva. Al tiempo, Casacuberta (2003, p. 92) lo corrobora: 
El artista no crea obras que han de contemplar, sino productos, instalaciones, software basado en la interactividad en un sentido genuino. El artista deja de ser un creador para ser un productor: en lugar de ser como el director de cine que crea la película, se parece más al ingeniero que construye una nueva cámara de video que ayudará al director a crear sus propias películas.

Esta forma de razonamiento interactiva en los niños y niñas participantes del estudio, supone la emergencia de nuevas capacidades de movilización, la puesta en escena de sinergias en torno a lo común y la disposición a invertir energía e imaginación para llevar a cabo ciertos propósitos. Según Lévy (2007, p. 140), la inteligencia colectiva implica la puesta en común de la memoria, la imaginación y la experiencia a través del intercambio y coordinación de información en tiempo real. Al respecto, augura la presencia de nuevos géneros de conocimiento, criterios inéditos de evaluación para orientar el saber y nuevos actores en la producción y tratamiento de conocimientos. Todo esto supone el uso de capacidades para trabajar colectiva y colaborativamente. Este tema será retomado en el capítulo final referido a la educación de las infancias contemporáneas.

\section{LOS SABERES: NUEVOS CAPITALES CULTURALES EN LA CDI}

El recorrido por las prácticas comunicativas de los niños y niñas involucrados en el presente estudio, muestra otra faceta fundamental en la relación entre formas simbólicas y CDI. Se trata de los saberes, una categoría que requiere de reflexión y otros análisis, más allá de su definición asociada con sujetos ilustrados o sociedades prósperas cuyas formas de organización del orden social obedecen a la aplicación de los sistemas de conocimientos canónicos y universales.

La introducción de esta perspectiva es necesaria, especialmente si se tiene en cuenta que el proyecto de modernidad temprana (de inspiración cartesiana), aún anclado en la escuela moderna y sus mecanismos de producción de la subjetividad de los niños y niñas, asume que la existencia del sujeto está supeditada a la razón (percepción de ideas claras y distintas, cogito ergo sum) y sus insumos fundamentales: los conocimientos universales (visión 
que predominó especialmente entre los siglos xvir y xIx) y los códigos disciplinares (legitimados gracias a la formalización de las disciplinas en los ámbitos universitarios, después de la primera mitad del siglo xx).

Lo que muestran las experiencias de Dany, Daniel, Maka, Valeria y Camilo, es que las formas de razonamiento analizadas anteriormente (gramáticas de ordenación del mundo como insumo para la racionalidad hipermedial y formas de interactividad como plataforma para la racionalidad interactiva) son distintas a la racionalidad logocéntrica e hipotético-deductiva del proyecto moderno. Estas nuevas racionalidades, que han sido engendradas en el magma de la CDI, fomentan tipologías de saberes en distintos niveles de profundidad y con variadas intenciones revestidas de importantes potencialidades. Son saberes que adquieren otro nivel de incorporación y de sentido en la vida de los sujetos. Son saberes que se producen en la hipermedialidad e interactividad, en los usos y apropiaciones de las aplicaciones de la Web 2.o, y en el conjunto de sensibilidades y socialidades que se tramitan en el contexto de los flujos y conexiones de la CDI.

Con el propósito de establecer las diferencias entre los sistemas de conocimientos canónicos (disciplinares y universales) y los sistemas de saberes, baste decir que estos últimos tienen dos posibilidades de explicación. En primer lugar, es claro que los sistemas interpretativos del mundo (natural, físico y socio-cultural) son diversos y dotados de diferentes fuentes, principios y formas de funcionamiento (para ser investigados, aplicados, validados o falseados) $)^{24}$.

No obstante, existen sistemas de saberes procedentes de comunidades originarias, de creencias ancestrales, de referentes estéticos, de movimientos sociales y de las contingencias propias de la vida cotidiana de las personas corrientes. Al intentar producir enunciados explicativos e interpretativos del mundo, estos sistemas de saberes no son ni más ni menos importantes que los lenguajes disciplinares y científicos. En lugar de ser opuestos e irreconci-

${ }^{24}$ Este es un debate fundamental en la historia de la epistemología y en la filosofía de la ciencia. Mientras que Popper planteó la necesidad de falsear las teorías como principio necesario para el progreso de la ciencia, Bachelard estableció la necesidad de identificar los obstáculos epistemológicos para propender por un nuevo espíritu científico. Por su parte, Feyerabend planteó ir contra el método y romper con la lógica del progreso de la ciencia. 
liables, son complementarios ${ }^{25}$. Su valor estriba en su capacidad para situar al sujeto y sus afectaciones en relación con los fenómenos del mundo.

La segunda opción explicativa para considerar la existencia de saberes en la CDI la provee el concepto de capital (cultural, social y simbólico), propuesto por el sociólogo francés Pierre Bourdieu (2010). Como es sabido, la obra de este intelectual es amplia y objeto de importantes debates en la actualidad. Uno de sus mayores aportes, además de introducir una perspectiva constructivista en el giro de la sociología de la década del setenta en el mundo, fue distinguir el funcionamiento del capital económico (como base primigenia del mundo capitalista-liberal) de otros capitales -social, cultural y simbólico-, los cuales son producto de la posición que ocupan los agentes sociales en los campos.

Los campos son espacios sociales y simbólicos que son asimilados por los agentes a través de procesos crecientes de socialización. Los campos tienden a especializarse en temas, sectores y aspectos sociales de la vida que van conformando lo que Bourdieu llama estructuras estructurantes, esto es, espacios cercanos a la incorporación de nociones y la producción de sentidos $^{26}$. Este es, tal vez, un marco compresivo de gran utilidad para reconocer que las relaciones producidas por los sujetos, como experiencia social para la producción de sistemas de saber y de acción, operan en doble vía (sujetos y sociedad). Esto significa que existen modos de interiorización del mundo en los sujetos y, a su vez, formas de objetivación del sujeto en el mundo.

${ }^{25}$ Este es un debate adelantado en distintos campos de estudio. Por ejemplo en la sociología de Berger y Luckman (2005), a la cual ya se ha hecho alusión, se analiza la construcción social del conocimiento y el valor del sentido común como orientadores de las prácticas sociales en la vida cotidiana. Por su parte, las teorías de la complejidad (Morin, 2006) han planteado la necesidad de establecer modos de complementariedad en torno al carácter contingente del conocimiento. Las perspectivas interculturales y decoloniales admiten que deben existir formas de traducción y colaboración entre los distintos sistemas de saber con el propósito de hallar nuevas maneras de interpretar el mundo. Finalmente, Lévy (2007) introdujo la noción de inteligencia colectiva para persuadir a las comunidades en la Web a hacer parte de procesos que contribuyan a producciones y creaciones colectivas (de orden participativo y colaborativo).

${ }^{26}$ Los campos, al ser parte del espacio social, pueden ganar autonomía (por ejemplo convirtiéndose en campos como el económico, el político, el religioso y el intelectual) en la medida en que se pongan en juego variables como las relaciones sociales, los intereses y los recursos propios. 
Dado que la sociedad es un sistema de relaciones de fuerza y de sentido entre los grupos y las clases (Bourdieu y Passeron, 2005), se puede admitir que un atributo fundamental de los campos está en la producción, difusión y preservación de determinados capitales que solo tienen valor en los límites de este espacio. No obstante, el despliegue de los capitales requiere de la conformación del habitus, el cual es inherente a la posición y acción social de los individuos. En términos generales, el habitus alude a un sistema de disposiciones adquiridas por medio del aprendizaje implícito o explícito que funciona como un sistema de esquemas generadores (Bourdieu, 2010).

Es un instrumento de traducción y ajuste entre los deseos individuales y las exigencias de cada campo. El habitus es un proceso en el que se produce y reproduce el sentido. En este confluyen tanto las estructuras objetivas (lo estable, lo instituido, la sociedad) como las emergencias sociales (lo emergente, lo instituyente y las socialidades). Mediante el habitus el orden social se inscribe en los cuerpos, posibilitando transacciones emocionales y afectivas. El cuerpo, a su vez, se objetiva en ese orden, dando lugar a conminaciones sociales. El habitus puede ser ubicado en las experiencias cotidianas: algunos aspectos no se perciben (percepción, pensamientos, interacciones); otros operan en el sentido práctico (aspiraciones, necesidades, deseos, potencialidades).

Por su parte, los capitales son acreditaciones y distinciones adquiridas por distintas vías que demuestran posesiones, dones y/o capacidades. Estos les permiten a los agentes sociales ocupar con cierta legitimidad un espacio dentro del campo. Se trata de una suerte de recursos invertidos en el campo, los cuales tienen diversas formas de funcionamiento en la esfera de la vida social. En todo caso, son capitales que están sujetos a propósitos de reconocimiento, gratificación y legitimación social.

Según Bourdieu existen cuatro tipos de capital: económico (dinero, bienes), social (asociaciones, membresías, parentescos), cultural (información, saberes, conocimiento) y simbólico (dones relacionados con el gusto, la sensibilidad y los valores que orientan la acciones). Sus expresiones también contienen diferencias. Por ejemplo, se pueden distinguir capitales objetivados (libros, archivos, objetos artísticos), subjetivados (consumos, apropiaciones, interiorización de la cultura) e institucionales (títulos, certificados, diplomas, acreditaciones). El rendimiento de estos capitales supone una inversión 
creciente de energía social, orientada generalmente hacia la reproducción de relaciones sociales dominantes.

La adquisición de este tipo de capitales juega un papel muy importante en las sociedades dado que son los medios vitales para que los agentes sociales ocupen algún lugar en el campo social y/o en sus campos autónomos. Para la sociología de Bourdieu (2010) -y seguramente para la de Elías (1997)- los procesos históricos están profundamente relacionados con realidades sociales que, a partir de variadas circunstancias que operan en la estructura social - pero también alrededor del carácter activo del sujeto- conllevan a la objetivación y la interiorización.

Esto significa que las realidades sociales pueden ser comprendidas atendiendo a dos mundos fundamentales en la vida de los sujetos. De una parte, al mundo de las reglas, las instituciones y los valores sociales, los cuales operan como condiciones limitantes, a la vez que como puntos de apoyo para la praxis. Y de otra, el mundo subjetivo e interiorizado, constituido principalmente por formas de percepción, de representación, de sensibilidad y de conocimiento ${ }^{27}$.

No obstante, Bourdieu (2010) plantea dos consideraciones que, probablemente a partir de la presente investigación, muestran variaciones significativas en el tiempo presente. En primer lugar, señala este pensador que los capitales culturales dependen de la escuela y de la familia dado que son los espacios privilegiados para consolidar aprendizajes y formas de percepción social vitales para el éxito de los individuos. En segundo lugar, la búsqueda permanente de maximizar los capitales dentro de los campos, conlleva al interés individual y social por reproducir las relaciones sociales de dominación.

Aunque no es interés de este estudio controvertir esta teoría ni las premisas que soportan los conceptos de campo y capital, se pueden identificar circunstancias prácticas distintas, relacionadas tanto con las fuentes sociales

\footnotetext{
${ }^{27}$ Se trata del doble movimiento, expresado tiempo atrás por Sartre, una particular forma de interiorización de la exterioridad y de exteriorización de la interioridad. Es posible también establecer algunos niveles relacionales, a propósito de este problema, entre el concepto de figuración de Norbert Elías (concebido como estructura interior de la personalidad, en relación con los social en el largo plazo), el habitus de Bourdieu (concebido como disposición), la conciencia práctica de Anthony Giddens y las interacciones y habituaciones correspondientes a la sociología fenomenológica de Berger y Luckman.
} 
y culturales de los capitales como con el carácter de dominación inherente al funcionamiento de los campos y los capitales. En términos simples, se puede asegurar a partir de lo analizado en este estudio, que la CDI es una fuente de saber central para la producción de capitales sociales, culturales y simbólicos. Las nuevas formas de razonamiento que surgen de este contexto comunicativo (hipermedial e interactivo) favorecen la sedimentación de otros capitales de manera individual y colectiva, los cuales se constituyen a partir de la asociación entre formas simbólicas y saberes. Se trata de sistemas de saberes con nuevos estatutos epistemológicos y prácticos, que orientan de manera divergente la conciencia y la acción de los sujetos.

De otra parte, aunque varios estudios señalan que las nuevas formas de comunicación en la Web 2.0 tienden a reproducir imágenes, productos y mundos ligados al capitalismo contemporáneo (informacional y cognitivo) y a un espectro empobrecido de lo social y de lo público (Debord, Baudrillard, Lipovetski), los resultados del estudio evidencian que operan diversos intereses, no siempre inscritos en la reproducción de las formas de dominación. Esto se constata al reconocer ciertas prácticas comunicativas que no solo muestran saberes técnico-instrumentales para navegar por la interfaz de $\mathrm{Fb}$, sino saberes compartidos, distribuidos y colaborativos con tendencia al aprendizaje y a la efectuación de proyectos de comunidad ${ }^{28}$.

Volviendo a las prácticas comunicativas del grupo analizado, es posible identificar tres tipos de capitales culturales que obedecen a la puesta en marcha de las racionalidades expuestas anteriormente (hipermediales e interactivas). En primer lugar, se encuentran capitales culturales basados en saberes ligados al funcionamiento de la interfaz de $\mathrm{Fb}$ y sus posibilidades de relación con otras mediaciones.

En segundo lugar, aparecen capitales culturales construidos a partir de los flujos de información y contenidos que circulan por la interfaz de la cDI, los cuales suelen adquirir matices de transmediación y prácticas de convergencia cultural. Y en tercer lugar, se identifican capitales simbólicos de carácter

\footnotetext{
${ }^{28}$ Es preciso insistir que, pese a estas diferencias, las nociones de campo, habitus y capitales (pensadas en el tiempo presente) han resultado útiles para abordar la categoría saberes en los contextos de las prácticas comunicativas analizadas en este estudio. Existe una crítica realizada por García Canclini (2010) al analizar el campo estético y las nuevas formas de participación que se ponen en juego para consolidar las formas de creación.
} 
intertextual que proponen diálogos de saberes y recomposiciones de textos hipertextuales e hipermediales, a propósito de los sistemas de necesidades e intereses que van apareciendo en el contexto de las hipermediaciones.

\section{SABERES EN TORNO A LOS USOS Y APROPIACIONES DE LA INTERFAZ}

En cuanto al primer tipo de capital cultural, se observa un conjunto de saberes que han emergido a partir del uso de la aplicación y la sumersión de estos niños y niñas en la interfaz de $\mathrm{Fb}$. El primer ejemplo lo proporciona Daniel (12 años), quien permanentemente está invadiendo los apartados que constituyen la estructura de la aplicación $\mathrm{Fb}$ a través de su perfil. En primer lugar, tiene actualizados sus datos de perfil y busca incluir aspectos nuevos cada semana (información básica, información de contacto, actividades e intereses).

En segundo lugar, utiliza textos, imágenes y enlaces permanentemente para hacer comentarios de diversos temas, generalmente los alusivos a sus asuntos de interés (fútbol, música y amigas). En tercer lugar, participa de casi todas las opciones básicas que provee la propia aplicación (mascota, test sobre amigos, horóscopo, etc.). Y finalmente, carga fotografías y participa en procesos interactivos, haciendo de vez en cuando comentarios.

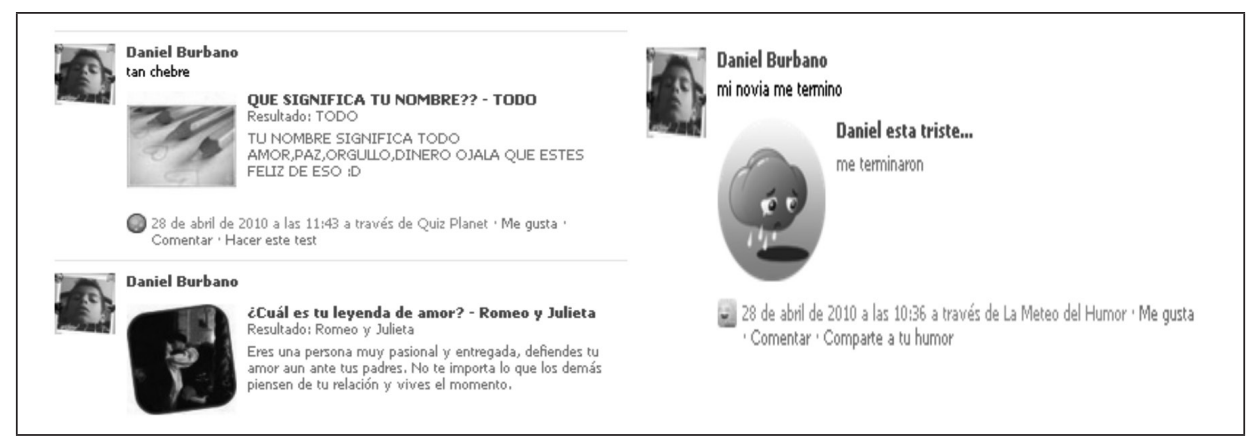

Imagen 12. Datos del perfil de Daniel

Como se observa, el caso de Daniel (12 años) muestra que la producción de algunos de sus capitales culturales está ligada a una serie de usos y apropiaciones que hace de las diversas aplicaciones que encuentra en $\mathrm{Fb}$ con cierta recurrencia. Los usos que produce hacen que descubra nuevas posibilidades de visibilizarse, procurando también distintos niveles de socializaciones con grupos de amigos. Estas formas de socialización, las cuales pueden resultar 
efímeras y fragmentadas -especialmente si se revisan los temas abordados (test, horóscopo, gift) - contienen algunos atributos que llaman la atención. Se trata de saberes que son producidos gracias a la interactividad (vínculos) que ejerce mediante distintos recursos, que empiezan evidenciar un saber sobre sí mismo a través de la organización de la información alusiva a preferencias y temas de su dominio como el fútbol, el Barcelona Fútbol Club, la música rock y los juegos online.

De este modo los capitales simbólicos asociados con los usos y apropiaciones, en el caso de Daniel, constituyen una mediación fundamental para producir saberes sobre sí mismo en/con y a través de Fb. Este dominio le permite navegar con cierta solvencia y lograr reconocimiento en el campo de la cDI. Al respecto, es importante recordar que para Bourdieu (2010) el capital implica un conjunto de propiedades (dones) imperceptibles, inefables y carismáticas, que parecen inherentes a la naturaleza del agente.

Este tipo de capital se consolida en la medida en que dichos atributos sean reconocidos por los demás, quienes son los encargados de otorgar crédito a aquellos que lo poseen. Las conversaciones de Daniel muestran que el dominio de sí mismo, apelando a la mediación de $\mathrm{Fb}$ y sus posibilidades, es reconocido por sus amigos. Además de ser un excelente usuario, convertirse en un videojugador online experimentado le otorga crédito y credibilidad en la esfera pública de su grupo de contactos (amigos).

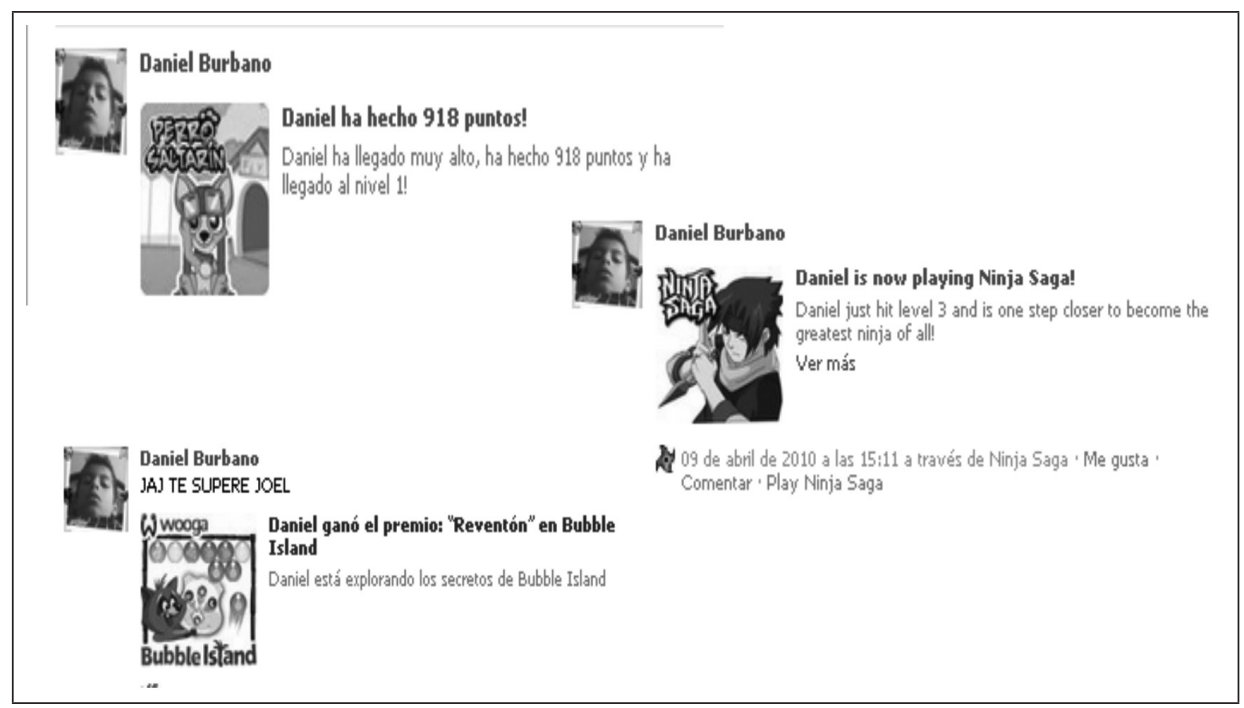

Imagen 13. Datos del perfil de Daniel 


\section{SABERES EN TORNO A CONTENIDOS Y TRANSMEDIACIONES}

El segundo tipo de capital cultural es aquel que surge del conjunto de flujos de información y contenidos que circulan por la interfaz de la cDI. Parece que la cristalización de saberes en sus usuarios no solo tiene que ver con el dominio de las aplicaciones y la visibilización de sí mismo, sino también con prácticas de transmediación y convergencia cultural. Al respecto, es importante recordar lo señalado en la primera parte de este trabajo.

Apoyados en Henry Jenkins (2008), se puede admitir que la transmediación es un fenómeno de imbricación entre medios, mediaciones y contenidos, cuya lógica de funcionamiento estriba en la producción de saberes, habilidades y dominios para encontrar relaciones y convergencias entre los fragmentos y piezas de las obras a través de varias interfaces y apuestas hipermediáticas. El ejemplo fue analizado mediante obras que circulan por las series ligadas a la hipertelevisión, las filmografías para la creación de mundos, los videojuegos online y los ova. Camilo Ryu Genkay se aproxima con varios recursos a este tipo de capital cultural.

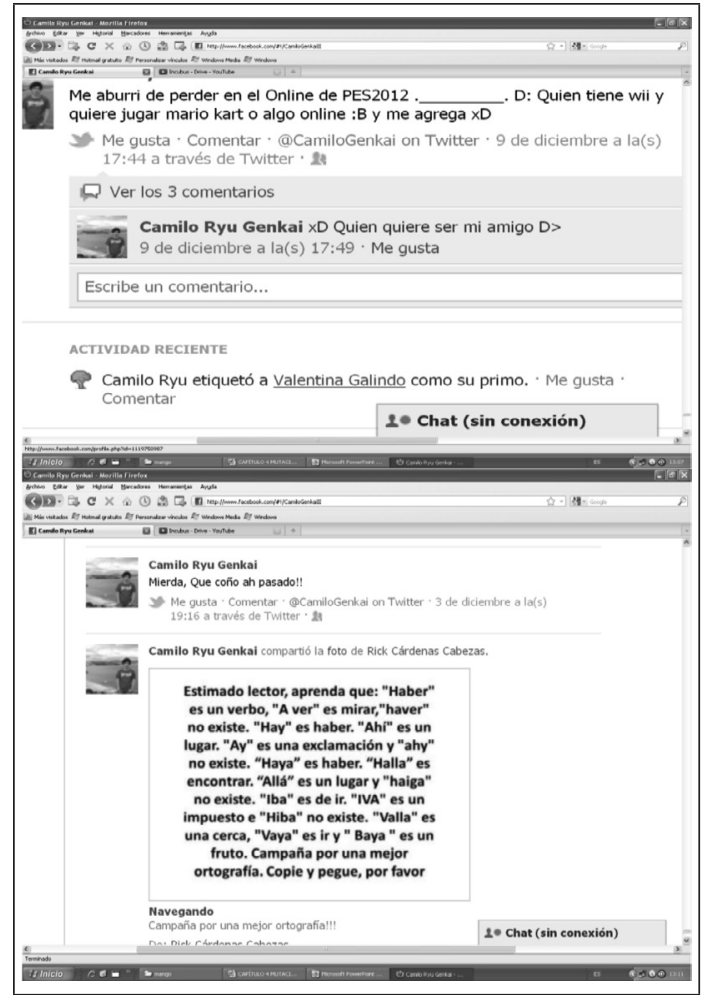

Imagen 14. Datos del muro de Camilo 
Este niño de 14 años propone dos experiencias relevantes para comprender la construcción de capitales culturales asociados con los flujos de contenidos y la transmediación con sus correspondientes inclinaciones hacia la convergencia. En primer lugar, introduce un texto escrito referido a la ortografía. Aunque se trata de la incorporación de una imagen de texto simple, orientado por algún episodio del momento, es destacable dado su interés por fomentar la buena ortografía y la introducción de una práctica de apropiación en la que usa un sistema convencional en una aplicación hipermediacional. En segundo lugar, se infiere la consolidación de un saber relacionado con sus prácticas como videojugador. De manera categórica declara que se aburrió de «perder en el Online de PES2012», y con una reafirmación semiótica -«D:»- procede a solicitarle a sus amigos algo simple de resolver: «Quien tiene wii y quiere jugar mario kart o algo online... y me agrega».

En este caso, Camilo presenta (de manera natural) un repertorio de información y saberes que dan cuenta de dominios adquiridos en la acción social, relacionados con juegos online y de consola. Adicionalmente, plantea su aburrimiento con algo que, al parecer, lo cansó y que ya no le genera mayores retos. Esta práctica, una vez más, ratifica la espontaneidad con la que estos sujetos navegan en el espacio de las hipermediaciones e intervienen sobre contenidos en clave de transmediación. La conjugación de lo online y offline es simple y se complementa con una oralidad «escrita», en la que Camilo sencillamente le propone a sus contactos «... y me agrega... :D». De otra parte, dentro de estos capitales culturales, comprendidos como dominios que articulan medios y mediaciones a través de flujos de contenidos, la música parece una compañía insoslayable que se vuelve saber:

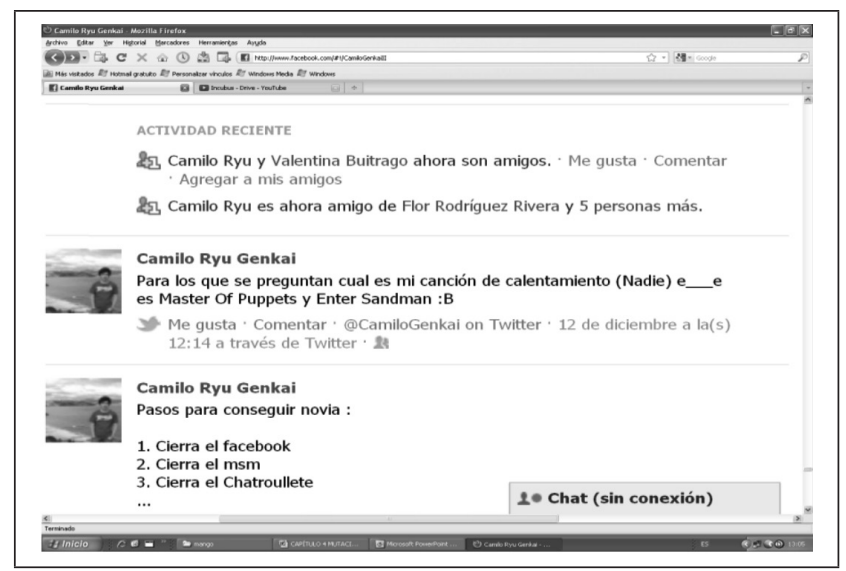

Imagen 15. Datos del muro de Camilo 
Camilo hace un planteamiento a sus amigos - pero también a curiosos y extraños- acerca de las canciones que le sirven para «calentar» cuando va a tocar la batería. Se trata de Master of puppets y Enter sadman, del grupo Metallica, cuyas sonoridades hacen parte del repertorio de opciones que le inspiran. En estas sencillas declaraciones en torno al Metal (que sirve de inspiración a Camilo), subyace la existencia de saberes que se objetivan como capitales culturales a través de sonoridades que transitan por distintos espacios: $\mathrm{Fb}$, radio convencional, canal YouTube y música propia (interpretación de la batería). Al respecto Marín y Muñoz (2002), de manera acertada, señalan: «Los pensamientos, lo que llaman ideología o filosofía, viajan también en la música y esto causa desconfianza entre quienes están más acostumbrados al conocimiento contenido en los libros».

La música interpretada (como lo hace Camilo) es también enlazada como video en su perfil de Fb, descargada de Ares, escuchada en su MP4 o en su celular y comentada en su muro. Su constitución como capital cultural es posible una vez se convierte en objeto de reflexión y dispositivo de identificación. Compartir música e ideas alrededor de una canción, un grupo o un género se convierte en una oportunidad de vinculación entre el yo y el nosotros, a través de anclajes que propician «(...) praxis bañadas de música, estilos sónicos y saberes maleados por el sonido» (Marín y Muñoz, 2002, p. 27). Vale señalar que tanto el espacio como el tiempo de las sonoridades que circulan en $\mathrm{Fb}$ y en otras mediaciones, se convierten en fuente, a la vez que en objeto de saber para estos sujetos. Las sonoridades conforman vehículos de patrones asociados con formas de cognición afectiva (emocional) y/o gestual (corpórea) (Yúdice, 2007), propensas a la generación de sensibilidades y socialidades crecientes.

Los niños y niñas del estudio suelen descargar música gratuitamente por Internet. Mientras que Daniela descarga temas y álbumes a través del Pc del Café Internet del barrio que luego deposita en su Mr4, Dany lo hace mediante el Pc de su casa, alojando contenidos en carpetas personalizadas. Por su parte Valeria guarda «su música» en el PC de su casa con el propósito de compartirla con los grupos de Fb, seguidores del género Metal. Finalmente, Maka suele hacer descargas de música directas desde su Black Berry para tenerla justo cuando la necesita, esto es, en situaciones de euforia o de tristeza.

La música en la vida de estos sujetos no es un simple accidente que acompaña su existencia. Tampoco se trata de ciertos referentes que aparecen 
localizados de vez en cuando en espacios o territorios específicos. Las prácticas de estos niños y niñas muestran que se trata de universos simbólicos en constante proceso de modificación, lo que da lugar a la presencia de diversas formas de expresión e identificación que estimulan su existencia. Además de las sonoridades asociadas con la música comercial y los grupos de moda en géneros como el Reguetón y el Tropi-pop (preferentes en Daniela y Dany), se evidencia el dominio de otros géneros, grupos y producciones artísticas de gran sofisticación estética, así como un conjunto de saberes alusivos a sonoridades marginales.

Las prácticas comunicativas de Camilo y Valeria muestran que han adquirido saberes complejos en torno a géneros como el Rock (especialmente asociados con el Grunge) y el Metal (Heavy, Black, Thrash, Folk, Speed, Brutal, Death, Power), los cuales incluyen no solo a bandas comerciales, sino también a grupos urbanos (marginales) que son conocidos solo por la Web. Por su parte, Maka es seguidora de música fusión, generalmente alimentada por géneros como el Ska, el Reggae y el Bhangra (remix de folclor oriental, soul y house). Estos sistemas de saber (no convencionales ni académicos) conforman progresivamente sedimentaciones de capital cultural de gran importancia para la vida de estos sujetos, pues les permite ser parte de comunidades con afinidades y propósitos comunes. Esto se puede corroborar en la afiliación (capital social) de algunos de estos niños y niñas a grupos en $\mathrm{Fb}$ como «Movimiento Rock por los derechos», «Amigos de la música fusión», «Metal y literatura».

De este modo, se puede concluir que estos capitales propician modos de ser y prácticas configuradoras de mundos de vida mediante sistemas de saber que se van organizando y coordinando colectivamente conforme a intereses, necesidades y preferencias. Se trata de mundos que se nutren de convergencias culturales para fomentar posicionamientos y potenciar formas de acción colectiva. Algunos críticos de estas tendencias socio-culturales plantean que estas prácticas no escapan de las industrias culturales de la música, ahora fomentadas por la compra de música y videos online.

No obstante, las expresiones de movimientos como Culture Libre, Manifiesto Remix y Creative Commons muestran que la hibridación musical, además de traer consigo nuevas posibilidades de apreciación estética, estimulan la creación colectiva. Aunque no sean parte de estos movimientos, las prácticas de varios de estos niños y niñas tienden a esta transgresión 
socio-cultural, al tiempo que enriquecen el universo de formas simbólicas que hacen posible la conformación de sus repertorios de capital. En relación con la música, Yúdice $(2007,45)$ constata:

Esta hibridez muestra que la industria de la música no está determinando el 8o\% de lo que se escucha en el mundo. Muestra además que una verdadera World Music se escapa de los cauces del marketing y de la nostalgia del folclore. Y no es porque entramos en los mundos que lo usuarios mismos suben a estos sitios que nos damos cuenta de ello.

\section{LOS SABERES DE LA INTERTEXTUALIDAD}

Finalmente, se encuentran los capitales simbólicos de carácter intertextual que están construidos a partir de articulaciones y recomposiciones de textos hipertextuales e hipermediales. Este tipo de capital es producido, atendiendo a intenciones específicas, en el marco de necesidades e intereses que van surgiendo en la actividad de flujos y conexiones que propicia la cDI. Maka y Valeria dan cuenta de estos saberes, los cuales implican formas de creación, incorporación de otros capitales y niveles prolijos de reflexión. Mediante el uso de Blackberry, Maka presenta la siguiente intertextualidad:

\section{BALANCE}

+ Escribir una nota

de Mak Sierra, el Sábado, 08 de enero de 2011 a las 19:08

el ego, el orgullo.....

saben que todo en exceso es malo cierto!!!!

pero tambien sabemos que todo tiene que tener un balance en nuestra vida!

como lo dije antes si no hay un balance y si no experimentamos de todo no sabremos que es su

contrario y no tendremos un balance y una bna toma de decisiones para nuestro futuro, por ende no

tendremos un ideal/nada claro!

estas cualidades defecto si no son bien utilizados te llevaran al olvido, la soledad y el fracaso!

confia en ti mismo, se fuerte, ten la frente en alto, ten tus metas claras y sobre todo ten la fuerza de

voluntad no solo de tomar decisiones sino de cumplirlas y hacerlas una realidad no solo para tu

beneficio sino para el de toda sociedad, o bno de los que te rodean!

ten en cuenta siempre tu futuro y mira siempre hacia delante, pero ten en cuenta el presente y que no

se te olvide el vivirlo por exagerar con el futuro ;)

Me gusta · Comentar - Compartir

['] A 4 personas les gusta esto.

Marlon Umaña pienso luego existo gran frase muy conocida poco

aplicada jeje... bacano verte escribir eso y una opinion propia la base

es la experiencia eso da argumento de eleccion. y la manera de

actuar solo es sincera cuando se tiene nociony sentido humano mas

alla de condicones sociales y culturales.cuando se deja de hacer por

uno y se piensa en el resto. :) cuidate :)

09 de enero a las 0:56 Me gusta $\propto 21$ persona

Mak Sierra me encata q tambn tengas un criterio propio y bastante fuerte como para callarme ;) :)

yerte como para callarme;) () culta si no que le da otro sentido a lo que refiere al sentido de la vida de un ser hu ...ver más 
Esta composición producida por Maka, al ritmo de una conversación por $\mathrm{Fb}$ de niños y niñas, es quizás una desafiante reflexión en torno a la vida, la toma de decisiones, el futuro y el presente. El objeto del comentario es la noción de balance y su relación con la toma de decisiones. Maka asume que las cualidades y defectos son elementos fundamentales que, si no son adecuadamente aprovechados, pueden llevar a las personas al olvido, la soledad y el fracaso. De otra parte, admite que la buena toma de decisiones debe incluir el beneficio para la sociedad y las personas más cercanas (seguramente familia y amigos).

Ante el imponente contenido, de manera ingeniosa Marlon incorpora en su respuesta a Descartes, señalando que las personas actúan con sinceridad cuando se posee sentido humano, más allá de las diferencias de clase, género o etnia. Al final, Maka admite que ha quedado callada ante la argumentación de su interlocutor y, remata aludiendo a Descartes, que el sentido de vida es central. Su capacidad argumentativa, fomentada por los capitales culturales que operan en medio de textualidades e intertextualidades, queda entrecortada dada la limitación de los caracteres de la aplicación «estado» en Fb.

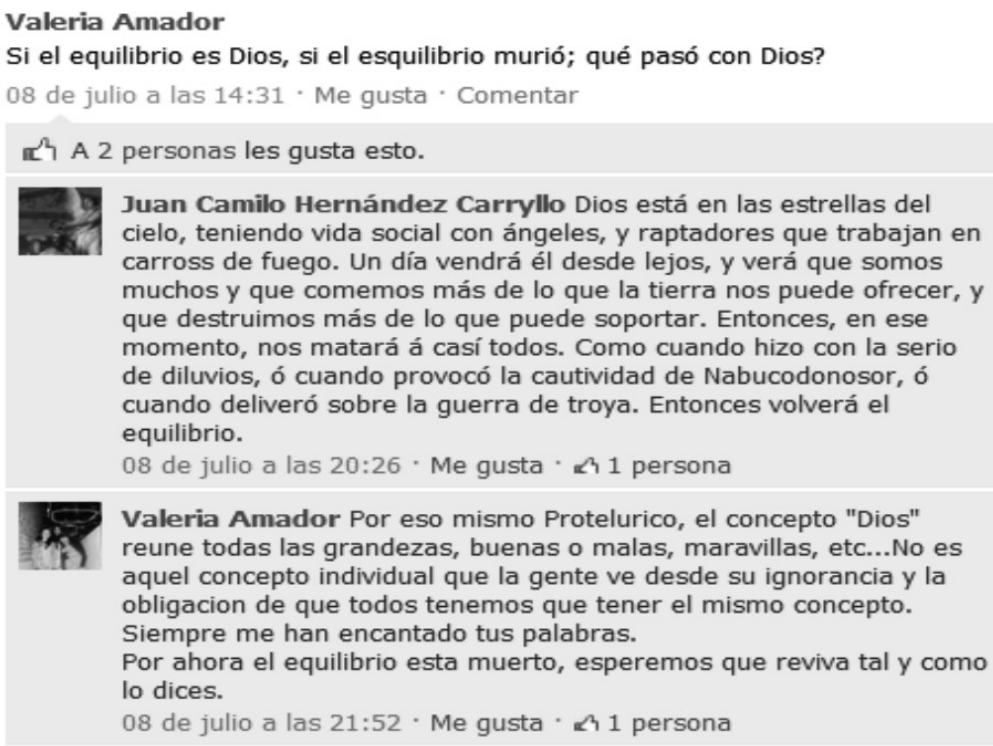

Juan Camilo Hernández Carryllo Dios está en las estrellas del cielo, teniendo vida social con ángeles, y raptadores que trabajan en carross de fuego. Un día vendrá él desde lejos, y verá que somos muchos y que comemos más de lo que la tierra nos puede ofrecer, y que destruimos más de lo que puede soportar. Entonces, en ese momento, nos matará á casí todos. Como cuando hizo con la serio de diluvios, ó cuando provocó la cautividad de Nabucodonosor, ó cuando deliveró sobre la guerra de troya. Entonces volverá el equilibrio.

Valeria Amador Por eso mismo Protelurico, el concepto "Dios" reune todas las grandezas, buenas o malas, maravillas, etc...No es aquel concepto individual que la gente ve desde su ignorancia y la obligacion de que todos tenemos que tener el mismo concepto. Siempre me han encantado tus palabras.

Por ahora el equilibrio esta muerto, esperemos que reviva tal y como lo dices.

08 de julio a las 21:52 - Me gusta * 1 persona

Imagen 16. Datos del muro de Valeria

De otra parte, Valeria provoca un debate en torno a la idea de Dios que articula saberes cotidianos, música y literatura. Su interlocutor reacciona 
con criterios que apelan a su propio sistema de creencias y cierto interés por interpelar los planteamientos de una niña de 14 años que emplea textos diversos y criterios propios para promover un tema complejo. El tema central que pone en cuestión la imagen de Dios es el rompimiento del equilibrio entre el hombre y la naturaleza. Valeria se pregunta, parafraseando la letra de una canción de la banda Café Tacva, si el equilibrio murió ¿qué pasó con Dios?

Juan Camilo introduce varias fuentes de saber en su réplica. De manera metafórica, presenta elementos que dan cuenta de la grandeza de Dios y de la subordinación del hombre a su voluntad: «(...) está en las estrella del cielo»; «(...) teniendo vida social con ángeles y raptores que trabajan en carros de fuego». Incorpora elementos para denunciar el problema del hombre en su transgresión a la naturaleza: «(...) comemos más de lo que la tierra nos puede ofrecer (...) entonces volverá el equilibrio». Como se observa, aparte de sus creencias puestas en escena, produce un texto que vincula fragmentos del Apocalipsis y elementos de su culto religioso.

Al final Valeria, sin reparos, le responde de manera afectuosa a Juan Camilo, afirmando que la idea de Dios no puede ser relativizada a las concepciones de cada persona ni a las imposiciones de los cultos religiosos. Aunque continúa convencida de la falta de equilibrio, presenta su esperanza en que éste vuelve a existir, tal como lo plantea su interlocutor.

La intertextualidad es un sistema de construcción de significados con varias exigencias. La primera es que el sujeto que produce y comprende textos sea capaz de reconocer el sistema de códigos y significados que usa para su composición. En segundo lugar, requiere organizar de manera coherente, pero con opciones de innovación, partes, fragmentos y piezas textuales que el sujeto coloca en escena mediante mensajes y obras con profundidad argumentativa y estética. Finalmente, la intertextualidad, entendida como un ejercicio de producción que se vale de sistemas de codificación diversos (incluso multi e hipermediáticos) provoca la generación de mundos posibles, en clave de plurilingüísmo (Bajtin, 1997).

Los planteamientos producidos por Valeria y su interlocutor (Juan Camilo) se aproximan a estos tres niveles de la intertextualidad. En primer lugar, las fuentes sociales y culturales de sus textos proceden de diversos puntos teóricos y prácticos. En segundo lugar, sus relatos tejen diversas perspectivas y trascienden el lugar común de las adhesiones de Fb. En tercer lugar, 
fomentan un diálogo de saberes en el que hay diferencias y hasta conflicto, dadas sus posturas religiosas. No obstante, sostienen sus posiciones (Bajtin, 1997). Estas posiciones se encuentran y posibilitan la reflexión y la conciencia. Finalmente, aunque no apelaron a otros recursos digitales, la discusión continuó en $\mathrm{Fb}$ y se valió de otros repertorios para defender las posiciones, pero también para llegar a consideraciones conjuntas. Esto es lo que Bajtin (1997) llama polifonía de voces.

Para finalizar, es importante indicar que la producción de capitales culturales se está dando en el contexto de la cDI. Esto significa que las nuevas formas de comunicación posibilitan saberes que tienen varias funciones: operan como mediaciones para ingresar en espacios de socialización de temas y problemas prácticos (por ejemplo indagar quién tiene otros juegos online) y teóricos (por ejemplo la vida o Dios); son insumos centrales para ocupar un lugar en un campo que no había considerado Bourdieu, esto es, el campo de las hipermediaciones; permite reafirmar posiciones y puntos de vista, lo que favorece el plurilingüismo y la polifonía de voces, al decir de Bajtin (1997); además de ser parte de expresiones prácticas en relación con las formas simbólicas producidas en el lenguaje, estos capitales fomentan transmediaciones e intertextualidades. Estos hallazgos serán retomados en el próximo capítulo dedicado a las subjetividades y la educación. 
[75]

SEGUNDA PARTE

MutaCiones DE LA SUBJETIVIDAD 


\section{SubJETIVIDAdES HIPERMEDIALES E INTERACTIVAS}

Las teorías en torno a la subjetividad son diversas y plantean distintas posibilidades analíticas, dependiendo de los referentes epistemológicos encargados de abordar las relaciones sujeto-sociedad-historia-cultura. Más allá de incursionar exegéticamente por sistemas teóricos para abordar esta categoría, esta parte del texto busca establecer las principales características de las subjetividades de los niños y niñas del tiempo presente, basados en los hallazgos del capítulo anterior.

Uno de los rasgos fundamentales de la escuela moderna en su proceso de consolidación fue la generación de ciertas tecnologías (mediante prácticas y discursos) tendientes a la regulación de los tiempos y los espacios de los estudiantes. Julia Varela (1995) expone rigurosamente, basada en Norbert Elías, cómo se procuró dicha regulación mediante las rutinas, las actividades escolares, el uso de textos y materiales, las evaluaciones y hasta las formas de habituación promovidas por la propia arquitectura escolar. Este también ha sido un planteamiento ampliamente difundido en la teoría de Michel Foucault (2005), la cual hace énfasis en categorías analíticas como buen encauzamiento, vigilancia, sanción normalizadora y panoptismo.

Los estudios arqueológicos sobre la infancia y la escuela (Varela, 1995; Narodowski, 1999; Sáenz, et ál., 1997) muestran, sin estar en total acuerdo, que sobre el cuerpo y la mente de los niños escolarizados fueron desplegadas 
estrategias, dispositivos y agentes que lograron la producción de una subjetividad ligada a la institucionalidad, el trabajo y el cuerpo nacional, esto es, la subjetividad moderna. Como se mostró en la introducción de este trabajo, el proceso de conformación de la subjetividad en América Latina y Colombia fue aún más complejo, pues se involucraron otras circunstancias socio-culturales, políticas y económicas asociadas con la experiencia colonial.

Al constituirse como sociedad moderno-colonial (a partir de finales del siglo XIX) en Colombia se fue cristalizando una matriz de poder que vinculó racismo, sexismo, patriarcalismo y clasismo, los cuales se sedimentaron en las mentes y cuerpos de los individuos para procurar obediencia y productividad. Este fenómeno ha traído como consecuencia, hasta el tiempo presente, la conformación de subjetividades particulares en los colombianos (entre ellos los niños y niñas), que están atravesadas por estas y otras condiciones.

Además de los principales aspectos que dieron lugar a la subjetividad moderna (productividad y obediencia) al emular el funcionamiento de un Estado nacional y los ideales modernos que son constitutivos del mismo, los niños y niñas en Colombia produjeron su subjetividad a partir de sucesos como el abandono, el trabajo, la discriminación por etnia y edad, así como su incorporación en los ejércitos (legales e ilegales) involucrados en el conflicto armado.

Hasta aquí dialogan las perspectivas de varios investigadores centradas en la producción de la subjetividad infantil a partir de su escolarización como medio efectivo para el control social y las intenciones modernizadoras de los estados nacionales en la región. No obstante, como se constató en el tratamiento de la categoría infancias, hacia la década de los noventa empezaron a aparecer otros escenarios y prácticas mediadoras de nuevas subjetividades en los niños y niñas.

En esta investigación se planteó de entrada que, para lograr comprender el advenimiento de estas nuevas subjetividades, es necesario indagar dos planos de existencia de los niños y niñas en el tiempo presente: el contexto socio-cultural en que están situados desde su nacimiento, haciendo énfasis en el repertorio audiovisual y transmediático erigido desde la década del noventa en la región, y las prácticas comunicativas que producen como partícipes de la comunicación digital interactiva. 
Se puede plantear una hipótesis: la subjetividad es una dimensión del yo y el nosotros que está inextricablemente ligada al programa cultural de la época y a las formas simbólicas producidas por los sujetos mediante sus prácticas. Bajo estos dos planos de existencia, los sujetos adquieren motivaciones, recursos y opciones para acontecer en el mundo. Tanto la mutación socio-cultural, cuyas manifestaciones se centran en el advenimiento de una nueva cultura audiovisual y repertorios transmediáticos, como la mutación comunicacional, expresada en prácticas comunicativas que introducen otras racionalidades y nuevos capitales culturales, permiten asegurar que estas condiciones han alterado notablemente a la generación que ha nacido y crecido entre las décadas del noventa y el dos mil.

De acuerdo con los hallazgos del estudio, estas mutaciones tienen incidencia en cuatro grandes dimensiones de la subjetividad: las percepciones del tiempo y el espacio; un desenvolvimiento socio-cultural que privilegia lenguajes y saberes para ejercer acciones colectivas; cierta propensión a producir y publicar ideas y propuestas en torno a los sucesos del mundo de la vida; y el despliegue de ciertas habilidades que favorecen no solo la interpretación de ideas y fenómenos sino la producción de presencia (Gumbrecht, 2005).

La subjetividad es un proceso de construcción del propio sujeto en el que intervienen diversas circunstancias que se despliegan en el tiempo y el espacio. Estas circunstancias aluden tanto a hechos de dominación como a prácticas de libertad. Ambas dimensiones explican cómo el sujeto ha llegado a ser lo que es (Foucault, 2005) y cómo puede llegar a ser algo en el futuro (Zemelman, 2007).

A lo largo del siglo xx y en el inicio del siglo xxi, la pregunta por el sujeto se ha convertido en uno de los temas privilegiados por parte de las ciencias sociales y la filosofía, dado el interés por comprender sus referentes y motivaciones para guiar sus actos. Si bien, es fundamental reconocer las dimensiones ontológicas de este problema, la entrada que se propone aquí para allanar el espacio de la subjetividad en los niños y niñas del tiempo presente, parte de la comprensión del conjunto de manifestaciones expresadas en la cultura, el lenguaje (a través de las formas simbólicas) y los saberes (como capitales culturales nuevos). 


\section{SABER, PODER Y SUBJETIVACIÓN}

Como se ha señalado, el abordaje de la subjetividad tiene en Michel Foucault una figura imprescindible. Este pensador, ampliamente conocido por sus distancias epistemológicas frente al estructuralismo, la hermenéutica y la fenomenología, inicialmente propone algunas resemantizaciones alrededor de nociones prototípicas de las ciencias sociales modernas como sujeto, historia, saber y poder. En la primera etapa de su obra, Foucault (1991) explora nuevas maneras de asumir al sujeto en las que no es dado definitivamente, pues su historia emerge de la historia de los dominios de saber y su relación con las prácticas.

Luego, estas definiciones se complejizan al colocar en el centro de sus estudios al sujeto moderno. En tal sentido, el estudio del sujeto implicó levantar amplias arqueologías de las localizaciones discursivas y proceder con una genealogía de las prácticas de saber/poder por la vía de discursos e intervenciones en instituciones disciplinarias ${ }^{1}$.

Además de un importante sistema de conceptos que le permitieron allanar las relaciones entre saber y poder, así como las lógicas de funcionamiento de las instituciones disciplinarias en su metamorfosis hacia la sociedad disciplinaria, Foucault se esforzó por identificar dos niveles de análisis para abordar los procesos de fabricación de la subjetividad. Se trata de un nivel en el que la modelación es ejercida sobre el sujeto mediante las fuerzas de constitución procedentes del orden social, esto es, por la acción de los influjos orientados por las instituciones disciplinarias en la delimitación del ser. Por lo general, operaciones como la individuación, la clasificación, la sanción normalizadora

\footnotetext{
I Estos términos hacen alusión a los dos métodos utilizados por Foucault en los trabajos que comprenden las dos primeras fases de su obra. Particularmente, la arqueología se ubica en aquellos trabajos que describen el análisis de la producción de enunciados que históricamente han ido apareciendo en medio de tensiones, continuidades y rupturas como mecanismos para nombrar y clasificar sujetos, saberes y órdenes sociales (ver Historia de la locura en la época clásica, 196I; Las palabras y las cosas, 1966 y la Arqueología del saber, 1969). La genealogía, por su parte, da cuenta de las condiciones y límites de las formaciones discursivas en la institucionalidad. Uno de los aspectos más sobresalientes de este segundo momento es la teoría del poder disciplinario, cuya base reside en el paso del panoptismo a las tecnologías disciplinarias (ver Vigilar y Castigar, nacimiento de la prisión, 1976. Para una mayor ampliación de la obra del filósofo desde su propia perspectiva, ver Foucault, 1991).
} 
y el examen, en el marco de lo que denominó buen encauzamiento, configuran las formas de ser y estar en el mundo del sujeto ${ }^{2}$.

El segundo nivel analítico está relacionado con los procesos de autoconstitución, la experiencia de sí y las prácticas de sí. Es una esfera de la subjetividad en la que el sujeto no es pasivo, establece mecanismos para enfrentar las fuerzas de constitución del primer nivel y supone la producción de una serie de medios para favorecer el autodominio, la resistencia y la creación en la cotidianidad. Las resistencias están distribuidas de manera irregular a partir de puntos, nodos y focos, los cuales se hallan diseminados con distintos niveles de densidad en el tiempo y el espacio. Su carácter móvil y transitorio empuja estas fuerzas a introducir líneas divisorias que se desplazan, rompiendo unidades y suscitando reagrupamientos (Foucault, 1991, p. 117).

De este modo se puede señalar que las resistencias no suponen el enfrentamiento entre dos clases sociales o la modificación radical de la estructura y la superestructura a través de la rebelión. Se trata de luchas que se derivan del campo estratégico de las relaciones de poder y que devienen en nuevas trayectorias de existencia en las prácticas y en los marcos del discurso. En una entrevista efectuada por Gregorio Kaminsky (2009) a Foucault, compilada en un texto titulado El sujeto mimetizado, dado a conocer solo hasta 1996, al ser interrogado por la definición del sujeto a propósito de la sujeción y la dominación en el marco de las instituciones de la modernidad, tratada en buena parte de los textos de su obra, el filósofo francés sentencia:

En primer lugar, yo realmente creo que no existe un sujeto soberano, fundacional, una forma universal de sujeto que pueda hallarse en cualquier parte. Soy muy escéptico y muy hostil, con respecto a este enfoque del sujeto. Creo, por el contrario, que el sujeto es constituido a través de prácticas de sujeción, o de una manera más autónoma, a través de prácticas de liberación, de libertad, como en la antigüedad; sobre la base, por supuesto, de una cantidad de reglas, estilos, invenciones, que se pueden hallar en el entorno cultural (2009, pp. 85-99).

\footnotetext{
${ }^{2}$ Para Foucault el poder está en todas partes. Esto significa que el poder no es una institución o una estructura, sino más bien el nombre que se presta a una situación estratégica compleja en una sociedad dada (199I, p. II2). El poder se ejerce a partir de innumerables puntos y en el juego de relaciones móviles y no igualitarias. No están en posición de exterioridad respecto de otros tipos de relaciones, sino que son inmanentes y constituyen los efectos inmediatos de las particiones, desigualdades y desequilibrios que se producen.
} 
Esta declaración contribuye a precisar dos planteamientos importantes para este trabajo de investigación. En primer lugar, los dos niveles en los que tiene lugar el proceso de constitución del sujeto y la fabricación de su subjetividad no operan de manera dicotómica o dialéctica, sino alrededor de relaciones de fuerza que se expresan en el discurso, las experiencias y las relaciones de poder, estas últimas organizadas en los espacios del micropoder o en la esfera de la biopolítica. Esto exigiría, dentro de un ejercicio de investigación sobre la subjetividad, abordar los dos niveles y observar sus modos de relación en zonas fronterizas, límites y surcos.

En segundo lugar, aunque es claro que Foucault nunca se ocupó de los problemas de la cultura, admite en su afirmación que el entorno cultural es el escenario en el que advienen estos procesos de constitución y, por consiguiente, un territorio definitivo para el análisis de las mutaciones ontológicas de una época en medio de circunstancias particulares.

De otra parte Gilles Deleuze, ligado a esta tradición intelectual, además de efectuar en la primera parte de su obra relecturas fecundas a los clásicos de la filosofía ${ }^{3}$, diseña una serie de neologismos -otras resemantizaciones(sociedades de control, líneas de fuga, rizoma, ritornelo, pliegues, entre otros), que ubican el problema del sujeto en una circunstancia histórica ligada a las formas de funcionamiento de la sociedad occidental y sus estéticas de constitución, en relación con lo que denominó régimen maquínico.

Si en Foucault categorías como sociedad disciplinaria, moldeamiento, individuación y discurso ocupan un lugar central en su teoría, formulaciones que se valen de conceptos como control, modulación, diferencia y lo maquínico ${ }^{4}$, serán fundamentales en los planteamientos deleuzianos. Para Deleuze,

\footnotetext{
${ }^{3}$ En estas relecturas se destacan los trabajos sobre Hume acerca del empirismo, Leibniz en relación con las mónadas, y Spinoza alrededor de su teoría de las pasiones. Ver Deleuze, 2006; 2007.

${ }^{4}$ Lo maquínico en términos de Deleuze y Guattari es una expresión en la que los deseos propios de las pulsiones de vida y muerte no se quedan en la individualidad, como lo planteó el psicoanálisis, sino que se incardinan en el aparato social y en las estructuras colectivas, a través de las máquinas deseantes (sujetos), las máquinas de regulación social (Estado e instituciones) y las máquinas semióticas (dispositivos que disponen la realidad de otro modo). Las máquinas deseantes, por tanto, se convertirán en el receptáculo de la actividad social y semiótica, en el que creencias y deseos podrán ser modulados y organizados alrededor de intereses subrepticios e implícitos. Ver Guattari y Rolnik, 2006.
} 
el devenir subjetivo pasa por tres planos: de consistencia, de referencia y de composición. Mientras que el primero está vinculado a la filosofía, el segundo y el tercero están inscritos en las apuestas de la ciencia y al arte, respectivamente.

$\mathrm{Al}$ respecto, surgen dos consideraciones importantes que se derivan de estas formulaciones asociadas con los tres planos deleuzianos. Aunque cada uno tiene sus propias categorías, es el plano de consistencia de la filosofía el que le permite a Deleuze dislocar los principios y las categorías propias del sujeto moderno y del pensamiento representacional que enmarca los grandes relatos de la modernidad.

Además de descentrarse de las condiciones lógico-deductivas que introdujo la metafísica y la ciencia moderna en sus planteamientos, demuestra que el plano de consistencia es el escenario más apto para favorecer la creación de nuevos conceptos, mostrando opciones y dejando abiertos los territorios por los que puede transitar el pensar. Es así como el devenir subjetivo cobra un valor fundamental para las luchas contemporáneas en medio de las fuerzas de los regímenes maquínicos que orientan las sociedades de control.

Por su parte, articulado al pensamiento de Guattari en una nueva etapa de su obra, Deleuze incorpora un metalenguaje que le permite desmarcarse de la tradición psicoanalítica y del estructuralismo lógico. De este modo, avanzando en el posicionamiento de un horizonte antideterminista del sujeto y la sociedad, procede a explicitar opciones de agencia que son expresadas apelando a recursos semióticos como la figura del rizoma. Solo bajo principios como la conexión, la heterogeneidad, la multiplicidad y la ruptura significante, señala el filósofo francés, será posible avanzar en otras formas de creación que ya no se disponen como esencias o universales. Se trata así de una suerte de pragmática que recompone las multiplicidades y el conjunto de las intensidades conducentes a nuevas creaciones en medio de las diferencias.

El funcionamiento de las líneas de fuga no solo son planteadas como desviaciones que escapan de las operaciones de dominación que recorren los espacios del micropoder o los meandros biopolíticos del cuerpo social. En Deleuze y Guattari se trata de una fuerza que puede hacer estallar los estratos, romper las raíces y conducir a nuevas trayectorias existenciales (Deleuze 
y Guattari, 2004, p. 34). Ya no se trata de un sujeto ligado a un proyecto colectivo que está determinado por la ideología o que se constituye a través de las elocuencias del inconciente ${ }^{5}$.

Si bien los planteamientos de estos autores se han convertido en un referente obligado para los estudios sobre la subjetividad, existen varios aspectos que, dado su énfasis epistemológico, no fueron tenidos en cuenta en sus teorías. Uno de ellos tiene que ver con el contexto histórico-cultural de las sociedades visto como un referente en el que los sujetos tramitan su existencia. Para los posestructuralistas lo importante es la acción del sujeto sobre sí mismo y sus posibles formas de despliegue (experiencia de sí, devenir, línea de fuga, plano de consistencia), así los sujetos se encuentren ubicados en sociedades disciplinarias o de control. En segundo lugar, se trata de teorías que asumen al sujeto como singular, soberano y contingente. Esta consideración desvanece la opción de resistencia y pone en su lugar lo colectivo, lo colaborativo y las identificaciones como opciones de liberación.

En tercer lugar, si bien no podría ser una exigencia dada la época en las que estos pensadores estudiaron dichos fenómenos, no fue de su interés reflexionar sobre la relación entre la subjetividad y las formas de comunicación o sobre las transformaciones del sujeto en relación con los medios y las tecnologías. Aunque las alusiones de Deleuze al funcionamiento de las sociedades de control contienen elementos importantes acerca de las características de la época y la incorporación del régimen maquínico, no precisa las formas potenciales que adquiriría la subjetividad en medio de estas condiciones en las sociedades contemporáneas.

Finalmente, el trabajo sobre la categoría subjetividad de estos intelectuales no precisó cómo observar la subjetividad en los niños y niñas. Las aproximaciones de Foucault a través de las categorías buen encauzamiento

\footnotetext{
${ }^{5} \mathrm{El}$ individuo de las sociedades de control es un sujeto cuyas trayectorias existenciales son planteadas como un trazo intensivo que se pone a trabajar por su cuenta bajo registros casi alucinatorios y sinestésicos, los cuales, en medio de mutaciones de diverso calibre, contribuyen a una liberación del significante completamente divergente.
} 
y sexualidades periféricas (1991, p. 93), aunque innovadoras, no responden a estas inquietudes.

\section{SUBJETIVIDADES SITUADAS}

Uno de los propósitos centrales del apartado anterior fue reconocer la importancia que tiene en la producción de la subjetividad de los niños y niñas tanto en el contexto socio-cultural (programa cultural) en el que han vivido desde su nacimiento, como en el conjunto de prácticas (comunicativas) que operan en el tiempo-espacio en su vida cotidiana. En estas aproximaciones, se constató que el estatuto ontológico, social y político de estos sujetos está pasando por variaciones fundamentales.

Esto permite afirmar que la subjetividad no es una dimensión del ser que esté exclusivamente ligada a las contingencias de su conciencia o de su voluntad. Los entornos que habitan los sujetos mueven fuerzas y poseen alcances que modifican sus formas de percibir, pensar y actuar. Sin embargo, la acción de cada sujeto, en medio de sus debilidades y vacíos, altera el funcionamiento de estos entornos de múltiples maneras. Por esta razón, la subjetividad implica observar una doble vía que explica las formas de ser y estar en el mundo de los sujetos: la interiorización de las formas simbólicas y materiales que provienen de las orientaciones institucionales y las estructuras sociales; y las iniciativas individuales y colectivas que pueden llegar a producir sentido y afectar dichas estructuras.

La construcción de la infancia no solo puede ser analizada a través de la acción de las instituciones disciplinarias o de los enunciados encargados de producir su subjetividad, comprendidos como procesos que evidentemente conducen a la implementación de formas de intervención institucional. Otro modo de comprender la construcción de la infancia parte de los mundos de vida que estos sujetos producen en su vida cotidiana. Dado lo expuesto hasta el momento, y a partir de los hallazgos de los apartados anteriores, se puede proponer la siguiente síntesis: 
Tabla 3: Mutación comunicacional 1. Racionalidad hipermedial

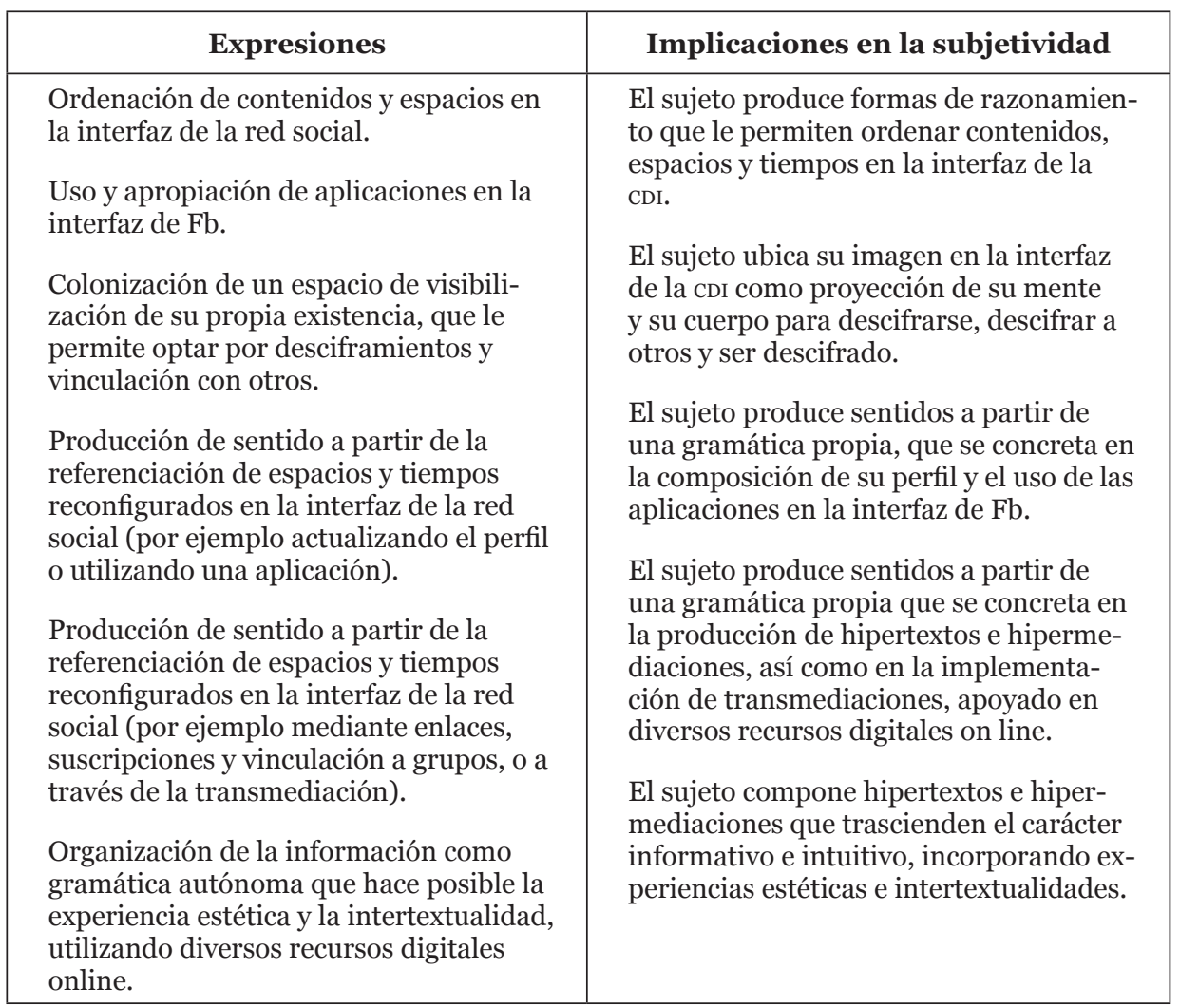

Tabla 4: Mutación comunicacional 2. Racionalidad interactiva

\begin{tabular}{|l|l|}
\hline \multicolumn{1}{|c|}{ Expresiones } & \multicolumn{1}{|c|}{ Implicaciones en la subjetividad } \\
\hline $\begin{array}{l}\text { Prácticas comunicativas que exigen de los } \\
\text { sujetos convertirse en gestores de un es- } \\
\text { pacio que apropian. }\end{array}$ & $\begin{array}{l}\text { El sujeto implementa formas de interac- } \\
\text { ción de su propio yo con la interfaz de la } \\
\text { cDI y los contenidos que usa y apropia. }\end{array}$ \\
$\begin{array}{l}\text { Producción de interactividades mediadas } \\
\text { por distintos vínculos entre el yo y el no- } \\
\text { sotros, cuya trama central es la emoción y } \\
\text { la provocación. }\end{array}$ & $\begin{array}{l}\text { El sujeto interactúa consigo mismo y con } \\
\text { otros introduciendo emociones, afectos y } \\
\text { provocaciones. }\end{array}$ \\
$\begin{array}{l}\text { Composición de interactividades que } \\
\text { operan en las fronteras del deber ser- ha- } \\
\text { cer y el ocio. }\end{array}$ & $\begin{array}{l}\text { El sujeto interactúa con otros introdu- } \\
\text { ciendo discursos y prácticas que se sitúan } \\
\text { en lad. }\end{array}$ \\
$\begin{array}{l}\text { Ejercicio de interactividades que son pro y la productivi- } \\
\text { pensas a la participación dada su natura- } \\
\text { leza abierta y reticular. }\end{array}$ & $\begin{array}{l}\text { El sujeto interactúa abriendo posibilida- } \\
\text { des de adhesión, reflexión y acción, po- } \\
\text { tenciando arquitecturas de participación. }\end{array}$ \\
\hline
\end{tabular}


Tabla 5: Mutación comunicacional 3. Los saberes (nuevos capitales culturales)

\begin{tabular}{|c|c|}
\hline Expresiones & Implicaciones en la subjetividad \\
\hline $\begin{array}{l}\text { Existencia de capitales culturales basa- } \\
\text { dos en saberes ligados al funcionamien- } \\
\text { to de la interfaz de } \mathrm{Fb} \text { y sus posibilida- } \\
\text { des de relación con otras mediaciones. }\end{array}$ & $\begin{array}{l}\text { El sujeto produce capitales culturales que } \\
\text { le permiten utilizar los recursos y aplica- } \\
\text { ciones que exige su participación en la red } \\
\text { social Fb. }\end{array}$ \\
\hline $\begin{array}{l}\text { Existencia de capitales culturales cons- } \\
\text { truidos a partir de los flujos de infor- } \\
\text { mación y contenidos que circulan por } \\
\text { la interfaz de la cDI, los cuales suelen } \\
\text { adquirir matices de transmediación y }\end{array}$ & $\begin{array}{l}\text { El sujeto produce y utiliza los capitales cul- } \\
\text { turales que hacen posible la transmedia- } \\
\text { ción mediante la composición hipermedial } \\
\text { e interactiva de diversos contenidos en la } \\
\text { Web. }\end{array}$ \\
\hline $\begin{array}{l}\text { Presencia de capitales simbólicos de ca- } \\
\text { rácter intertextual, que proponen diá- } \\
\text { logos de saberes y recomposiciones de } \\
\text { textos hipertextuales e hipermediales, a } \\
\text { propósito de los sistemas de necesida- } \\
\text { des e intereses que van apareciendo en } \\
\text { el contexto de las hipermediaciones. }\end{array}$ & $\begin{array}{l}\text { El sujeto produce y utiliza capitales cultu- } \\
\text { rales de carácter intertextual que favorecen } \\
\text { el diálogo de saberes y la polifonía de voces } \\
\text { mediante un sistema de necesidades e inte- } \\
\text { reses que se va consolidando en el mundo } \\
\text { de la cDI. }\end{array}$ \\
\hline
\end{tabular}

Fuente: propuesta del autor

Este recorrido evidencia que advienen nuevas subjetividades en los niños y niñas que se han incorporado en y a través de un programa cultural que produce nuevas visualidades y sonoridades, y que fomenta prácticas comunicativas en un espacio-tiempo llamado cDI. Se trata de subjetividades hipermediales e interactivas que se expresan de diversas maneras. La síntesis expuesta permite destacar seis grandes expresiones de estas subjetividades:

- Nuevas percepciones del tiempo y el espacio mediadas por el acceso a narrativas, géneros y formatos que amplían los sistemas de significación, lo que favorece otros modos de socialización, sensibilización y acceso a saberes.

- Construcción de identificaciones sociales auspiciadas por nuevos sistemas de intereses y necesidades que pueden potenciar lo común como opción de vida.

- Inmersión en transmediaciones que amplifican lo sensorial visual, lo auditivo y, eventualmente, lo táctil, como mediación que favorece la producción de repertorios senso-perceptuales, estéticos y cognitivos.

- Prácticas hipertextuales e hipermediales que posibilitan arquitecturas de participación. 
- Saberes emergentes que se convierten en capitales culturales, caracterizados por la hipermedialidad, la interactividad y la intertextualidad, que favorecen la producción de sí, la colaboración y la participación.

- Deseos que se expanden y placeres que pueden ser vividos mediante acceso a contenidos (de lo íntimo, lo prohibido, la tragedia y la derrota humana) sin filtros ni censuras.

Estos hallazgos corroboran parte de la hipótesis planteada desde el inicio: los niños y las niñas están pasando por mutaciones que dan cuenta del tránsito de la subjetividad moderna (mediada por la escuela y la familia) a subjetividades emergentes (hipermediales e interactivas) que tienen en el programa visual y transmediático contemporáneo y la CDI no solo el contexto, sino la fuente social y cultural que les permite ser sujetos, comprender la realidad y habitar el mundo de ciertas maneras. Este devenir, además de divergente y dinámico, contiene potencialidades considerables para proponer otras educaciones posibles en Colombia y la región.

En términos generales, y sin desconocer el importante legado de los autores mencionados, se puede afirmar que las subjetividades emergentes que dan cuenta de la condición contemporánea de las infancias, descansan en dos aspectos claves: el carácter situado de las subjetividades, el cual se apoya en la reafirmación del yo (múltiple) en espacios desterritorializados de la comunicación y la cultura como posibilidad de coexistencia plural y singular; y la dimensión interactiva del yo-otro, la cual se apoya en las temporalidades y diacronías glocales que emergen de la nueva cultura audiovisual, la transmediación y la CDI. Este aspecto de la subjetividad se radicaliza a través de la polifonía de voces que subyace a esta destemporización.

\section{EL CARÁCTER HIPERMEDIAL DE LA SUBJETIVIDAD}

Asumir el carácter situado de la subjetividad contemporánea es recobrar el lugar que tiene en los procesos de constitución y subjetivación de los individuos y grupos, los sistemas de significación, procedentes de las diversas fuentes sociales y culturales del mundo de la vida: discursos y prácticas (según Foucault, 2005), pero también interacciones, modos de socialización, formas simbólicas, saberes (científicos, escolares, populares, estéticos, ancestrales, entre otros), repertorios culturales, artefactos, medios y mediaciones. 
Esto significa que no solo los procedimientos del saber y el poder que se erigen en las instituciones de encierro determinan los modos de ser sujeto. Se puede afirmar que los programas culturales, en medio de sus intenciones de control y sus expresiones legítimas en torno a su potencia política, ética y estética, hacen posible también la producción de subjetividades.

Esta alusión a lo situado implica también otra afirmación: los niños y niñas pueden convertirse en protagonistas no solo debido a sus presuntas carencias y obsolescencias, tal como lo retrata la noción moderna de infancia (en singular), sino que poseen atributos y potencialidades que devienen en acontecimiento. Pierre Lévy (2007) plantea lo virtual como un potencial que está ahí, pero que requiere ser promovido mediante la acción social y que encontraría su mayor impulso en el programa de la cibercultura ${ }^{6}$.

La invitación de Lévy (2007) sirve para considerar lo situado como una nueva manera de asumir la relación sujeto-mundo, esto es, como un conjunto de prácticas que, mediadas y potenciadas, promueven nuevas formas de pensamiento y acción. Estos planteamientos también pueden ser analizados a través de lo que Mauricio Lazzarato (2006) denomina filosofía del pensamiento menor. Los principios fundamentales de esta filosofía descansan en lo diverso, lo diferente, lo minoritario y la multiplicidad, como otras maneras de entender la condición humana contemporánea.

La aproximación de Lazzarato (2006) a esta concepción de subjetividad resulta útil para el presente ejercicio. Además de proporcionar nuevas explicaciones al advenimiento de los sujetos contemporáneos en medio de las condiciones del nuevo capitalismo y de la incorporación de las tecnologías y de la Web en la vida social, sus planteamientos no se anclan en los marcos explicativos alusivos a la posmodernidad o a la perentoria incorporación del cosmopolitismo racional (de corte liberal) en las instituciones sociales. En lugar de la declaratoria por una radicalización de la modernidad o el cumplimiento de sus promesas incumplidas, hay en estos planteamientos una articulación novedosa entre el concepto de acto ético (Bajtin, 1997) y la necesidad de construir una política del acontecimiento.

${ }^{6}$ Es importante recordar que Pierre Lévy (2007, p. 83) propone un programa, en el contexto de la cibercultura, caracterizado por la adopción de lo universal sin totalidad, una mirada distinta a los movimientos sociales en la cibercultura, un reconocimiento del arte cibercultural y un nuevo modo de comprender la producción de saberes en la cibercultura. 
Esta perspectiva permite afirmar que las subjetividades situadas aluden a una ubicación específica de orden espacial, que los sujetos asumen al optar por la construcción de mundos de vida reafirmados por un yo con múltiples rostros y posibilidades de expresión. Particularmente, el yo múltiple de los niños y niñas en los contextos de la cultura audiovisual, las transmediaciones y la CDI no busca convertirse en identidad única ni esencia. Se trata de un yo que se ficcionaliza y que encuentra un espacio desterritorializado para expresar aquello que es o que busca ser ${ }^{7}$. Por esta razón, el esfuerzo que realizan estos sujetos por situar su mente y cuerpo en un espacio digital e interactivo (múltiple y evanescente) implica narrar y narrar-se como otra opción de existencia.

Al respecto, es importante recordar que la subjetividad moderna ha estado tramitada especialmente en espacios institucionales que, al decir de Foucault (2005), fomentan el buen encauzamiento y la normalización. Particularmente la arquitectura de las instituciones modernas, basadas en el panoptismo, los muros y la reclusión, han hecho posible la conformación de sujetos obedientes y productivos para el sistema socio-económico y político predominante. Lo que predomina en estos espacios son destrezas y procedimientos, a partir de la orientación de un eidos (discursos y enunciados), que proviene de regímenes de saber-verdad y de estrategias prescriptivas de las propias instituciones estatales.

De este modo el yo comunicativo, digital e interactivo que se está construyendo en el contexto de un programa cultural caracterizado por conexiones

\footnotetext{
${ }^{7}$ Al respecto es importante aludir al trabajo de Nietzsche titulado Sobre verdad y mentira en sentido extramoral (1970), en el cual problematiza la dicotomía de la modernidad entre hombre racional y hombre intuitivo. Mientras que el primero desea dominar la vida mediante la previsión, el segundo solo toma como real la vida disfrazada de belleza, asumiendo como verdad únicamente aquello que le interesa. De ahí que la ficcionalización de la vida se convierta en una estrategia permanente para sobrevivir en medio de las apariencias sociales. Por su parte, el legendario trabajo del sociólogo canadiense Erving Goffman titulado La presentación de la persona en la vida cotidiana (1993) proporciona otros elementos sobre la construcción del yo: las personas son algo parecido a actores dramaturgos que interactúan tanto en la escena como en la trasescena (backstage). Mientras que en el escenario existen todas las interacciones que la gente hace delante de los demás, en la parte trasera dominan las formas que se mantienen ocultas o se guardan. Los hombres son como actores que se esfuerzan permanentemente, a lo largo de su vida social, por transmitir una imagen convincente de sí mismos frente a los diversos auditorios a los que se enfrentan (la familia, los amigos, la escuela, la oficina, etc.). No importa lo que uno sea realmente, sino lo que parece ser.
} 
y flujos, trasciende el carácter solipsista del sujeto esencial de la modernidad y se incorpora en una estética de la existencia que no solo le permite decir-se y nombrar-se, sino inventar-se. Para tal efecto, la narrativa y los saberes del mundo de la vida, orientados por nuevos sistemas de intereses y necesidades, han de favorecer el despliegue de la subjetividad y la posibilidad de transitar de un yo dado y constituido a un yo situado, encarnado, virtualizado y en construcción continua. Aunque el tema de la narrativa es amplio y requeriría de mayor profundización, se puede admitir que en las sociedades del tiempo presente la narración se ha convertido en un modo de razonamiento y una posibilidad de ser testigo-artífice del acontecimiento ${ }^{8}$.

Lo anterior corrobora que las infancias del tiempo presente no están en correspondencia con el sujeto esencial y universal de la modernidad que ha sido enunciado por la metafísica. Tampoco se trata de aquel sujeto que fue explicado por el estructuralismo como fiel reflejo de las estructuras sociales, sus invariantes y dicotomías. Esta mutación ha sido presentada recientemente por varios pensadores. Particularmente Lazzarato (2006) parte de la existencia de una crisis heredada por los grandes relatos de la modernidad, los cuales se fundaron en un sujeto atrapado en una matriz de poder que funcionó solo a partir de dicotomías: hombre-mujer, blanco-negro, civilizado-bárbaro, Estado-ciudadano, obrero-capitalista, adulto-niño.

Lazzarato (2006) se apoya en la teoría de la exterioridad de William James para argumentar la relación sujeto situado-coexistencia subjetiva9 ${ }^{9}$ Tempranamente, hacia 1914, James planteaba que estar en el mundo suponía habitar

\footnotetext{
${ }^{8} \mathrm{Al}$ respecto es necesario aludir a los planteamientos de Jerome Bruner sobre el pensamiento narrativo. El psicólogo norteamericano, en sus dos libros fundamentales (Realidad mental y mundos posibles, 2004; y Actos de significado, 1991) plantea que existen dos modos diferentes de conocer: el paradigmático y el narrativo. La modalidad paradigmática o lógico-científica intenta operar como un sistema matemático formal de descripción y explicación. La modalidad narrativa consiste en contarse historias de uno a uno mismo y a los otros. Al narrar estas historias, los individuos van construyendo significados con los cuales las experiencias adquieren sentido.

9 Según las fuentes de la historia de la filosofía, James fue el fundador del pragmatismo. Luego de un profundo estudio de los sistemas de pensamiento propuestos por Kant, Fichte y Hegel, el filósofo norteamericano planteó como premisa que es necesario reducir lo verdadero a lo útil, negando el conocimiento teórico en diversos grados. Esto supone asumir el intelecto no como mecanismo para investigar y conocer la verdad, sino para que el hombre se oriente en la realidad. El conocimiento humano recibe su sentido y valor de su destino práctico. Su verdad, sentencia James, consiste en la congruencia de los pensamientos con sus propios fines prácticos.
} 
diversos sistemas al mismo tiempo, bajo la aceptación de la coexistencia del pluralismo y la singularidad. En la exterioridad no hay esencia ni substancia, de modo que lo incompleto, lo singular y lo desordenado configuran otra manera de producción. Aceptar que el sujeto puede ocupar varios órdenes simbólicos en diversos «territorios», supone descentrarlo de un modo de constitución basado en la determinación del enunciado y la institución. Esto permite afirmar que su proceso de subjetivación depende de un flujo de relaciones exteriores (flotantes y variadas) que, en este caso, contribuyen decididamente a posicionar el mundo del pluralismo como acontecimiento.

La vinculación de los niños y niñas a nuevos repertorios audiovisuales y escenarios transmediáticos promueve formas de ser que suelen estar asociadas con las nociones de coexistencia y exterioridad. Se trata de formas de presencia que tienen lugar en espacios de flujos y conexiones permanentes propios de la cDI. En este caso, la coexistencia de su presencia en diversos sistemas de paso (redes sociales, blogs, videojuegos, canales de video, wikis, mensajes de texto, reproductores de video y música, etc.) favorece otras formas de subjetividad, que son estratégicas para la re-creación permanente del yo. Se trata de fuentes que les permiten socializar y acceder a saberes ligados a necesidades e intereses, a modificaciones en sus modos de percibir y pensar, y a la construcción de identificaciones.

Lazzarato (2006), parafraseando a James, plantea que aceptar la existencia de las cosas, una por una, independientemente de la posibilidad de reunirlas todas a la vez, es un primer paso para romper la lógica de la totalidad y de lo universal. En cuanto a los hechos y las experiencias, admite que un cierto número de hechos es posible solamente bajo una forma distributiva en donde el conjunto, al ser organizado por cada unos (en plural), no requerirá de interpretaciones ni experimentaciones para acontecer. La posibilidad de producir gramáticas propias y formas de ordenación de espacios en los que estos sujetos le dan sentido a su existencia, frente a sí mismo y a otros, admite la presencia de modos de razonamiento divergentes (coexistenciales, distributivos, hipermediales e interactivos).

Así, las relaciones se liberan de todo fundamento, de toda substancia y de toda atribución esencial (Lazzarato, 2006, p. 23). Esto significa que los hechos y las cosas se relacionan con otras de muchos modos, sin que dependan de una única relación que las determine. Las subjetividades tramitadas en escenarios de marcada hipermedialidad e interactividad constituyen mundos plurales posibles, conjuntos que no se componen de la sumatoria de las par- 
tes, pues aunque las porciones conduzcan a la unidad, cada cosa sigue siendo autónoma y propensa a producir relaciones. Por esta razón, la vinculación de los niños y niñas a nuevos contenidos, géneros y narrativas (en Tv, filmes y transmediaciones) fomenta la producción de formas simbólicas, tendientes a la coexistencia y distribución de relaciones que se concretan en socialidades, sensibilidades y saberes.

El mundo del pluralismo, según Lazzarato (2006), renuncia a la forma todo y se instaura en la forma cada, asunto que pasa por la actividad de las discontinuidades y disyunciones reales que promueven movimiento e innovación. Este movimiento es posible de imaginar mediante la figura de una inmensa red de relaciones que posibilita la creación como un modo de constitución pluralista, distributiva y temporal. En el caso de los niños y niñas partícipes de este estudio, la sumersión que provoca el permanente proceso de transmediación favorece la amplificación de dimensiones fundamentales de las subjetividades para acontecer, como la visual, la auditiva y la táctil. Estas dimensiones fomentan la generación de recursos senso-perceptuales, estéticos y cognitivos que potencian el pensamiento y la acción.

\section{SUBJETIVIDADES INTERACTIVAS}

Otro elemento central en las subjetividades contemporáneas mediadas por la nueva cultura audiovisual, la transmediación y la CDI, es la conformación de nuevas prácticas sociales digitales e interactivas. La sociología fenomenológica se ha referido a la práctica social como un atributo inherente al sujeto y a las sociedades. Particularmente, la distinción hipermedial e interactiva que caracteriza a los niños y niñas que participaron de este estudio, está íntimamente relacionada con un tipo de prácticas, asociadas con dos nuevas lógicas de pensamiento y acción que desordenan las convencionales nociones de socialización primaria y secundaria ${ }^{10}$ : la red y la comunidad.

\footnotetext{
${ }^{10}$ Como se ha planteado anteriormente, los fenómenos de la CDI y la cibercultura han alterado notablemente los modos de socialización, llamados socializaciones primaria y secundaria. En la sociología fenomenológica de Berger y Luckman, (2005), la socialización primaria se iniciaba en la vida del niño a través de la familia y luego se extendía hacia la socialización secundaria (instituciones sociales). Como se pudo constatar, estas socializaciones han sido alteradas sensiblemente dadas las nuevas experiencias de los niños en los espacios pantallizados e hiperconectados de la CDI.
} 
La concepción de red y de comunidad en la cDi como escenario en el que se producen subjetividades en niños y niñas tendientes a producir acontecimientos, implica apelar a dos conceptos: agenciamiento posible y polifonía de voces. En relación con el primer concepto, Lazzarato (2006) plantea que, en el contexto de la política mundo, la cual se nutre de nuevas distribuciones de lo posible, el carácter interactivo de las subjetividades conlleva necesariamente a la efectuación. Efectuar posibles, entendido como aquello que emerge del acontecimiento, es abrir lo imprevisible y arriesgar ideas, posiciones y prácticas como oportunidad de reconversiones subjetivas y desprendimientos de órdenes instituidos.

En esta oportunidad, Lazzarato (2006) acude a las obras de Gottfried Leibniz y Gabriel Tarde para delimitar las relaciones necesarias entre posibles, agenciamiento y efectuación. Particularmente se vale de la figura de la mónada propuesta por Leibniz para expresar la importancia que contiene la complementariedad entre el todo y las partes. No se trata de la definición del todo como sumatoria de las partes, sino de comprender el valor de cada parte como unidad constitutiva del mundo y fuerza autónoma del cambio. Es un flujo interminable en el que la mónada favorece la conformación de opciones posibles a partir de su singularidad y no de su esencialidad.

Así, el proceso de constitución del mundo y de la subjetividad humana parte del acontecimiento y no del eidos, proveniente con frecuencia de los sistemas de conocimiento que se abrogan de la verdad y de las teleologías determinadas por las instituciones modernas en su interés por gobernar y encauzar a los anormales, carentes y desviados. Aunque Leibniz afirma que lo posible ya está creado en la mónada, Lazzarato lo interpela señalando que lo posible hay que crearlo, o al menos producir sus condiciones de existencia. Los mundos posibles pueden crearse en la medida en que se fomenten las condiciones de tiempo y espacio pertinentes para favorecer prácticas, socialidades y pensamientos a partir de la multiplicidad de formas que provee el lenguaje, las sensibilidades y los saberes en el mundo de la vida.

Al respecto, plantea Lazzarato (2006) que las relaciones y los acontecimientos deben pasar de las jerarquías promovidas por las instituciones (mediante la regulación de los tiempos y los movimientos) a las redes y comunidades, las cuales fomentan otros tiempos y temporalidades. Se trata de tiempos simultáneos que rompen con la lógica de las cronologías, las sincronías y las 
ordenaciones de las instituciones modernas. Los tiempos orientados por la lógica de redes y comunidades son distintos a los de las instituciones dado que articulan lo local y lo global, conformando glocalidades ${ }^{11}$.

Reconocer las pantallas y los actos que allí se producen, hace posible que el sujeto emerja en su multiplicidad y en su gusto por compartir con los otros, aunque estén ubicados en lugares remotos. Esto implicaría reconocer que los espacios gestionados, particularmente bajo los referentes de la nueva cultura audiovisual, las transmediaciones y la cDI, promueven agenciamientos y efectuaciones.

La forma de funcionamiento de estos espacios (en red y en comunidad) se basa en dos procesos fundamentales: el agenciamiento colectivo de enunciación y el agenciamiento de efectuación. El primero implica aportar expresiones, pensamientos y acciones para potenciar otras posibilidades de existir en tanto sujetos y grupos. El segundo proceso exige poner las mónadas a disposición, aprovechando su fuerza y su diferencia, para consolidar aquello que está presente en la potencia de la enunciación, esto es, lo común y lo colectivo.

En suma, el agenciamiento de efectuación es un acontecimiento en el que se actualiza lo posible. Se trata de relaciones que van más allá de las tensiones dicotómicas fomentadas por las perspectivas del sujeto y la sociedad que instauraron la metafísica moderna y las instituciones que han hecho posible el Estado moderno. Tanto el agenciamiento de enunciación como el de efectuación son escenarios plurales y singulares (al tiempo) e impugnan las legitimidades establecidas basadas en el conflicto entre dos partes (obreros/ capitalistas, hombres/mujeres, trabajo/descanso) como medio para imponer un ideal o un orden. La impugnación que supera las dicotomías impulsa el nuevo proceso de subjetivación en el acontecimiento ${ }^{12}$.

\footnotetext{
"Aunque es un neologismo, el concepto ha sido planteado por Arturo Escobar (2005) como la construcción de tiempos y espacios alternativos en los que lo local está en lo global y viceversa. Este llamado se inscribe en una perspectiva crítica de lo global, el cual ha sido posicionado como el escenario del capital, la historia y el poder. A cambio, plantea Escobar, lo local adquiere fuerza y se convierte en la base constitutiva de lo global (insubordinado y antihegemónico).

${ }^{12}$ Lo corrobora Lazzarato (2006, p. 42): «(...) consumar los posibles que un acontecimiento ha creado implica modalidades de actuar y de padecer que son muy diferentes de la acción de un sujeto sobre un objeto o de un sujeto sobre otro sujeto».
} 
Esta perspectiva que enlaza subjetividad, agenciamiento y efectuación se consolida mediante la emergencia de prácticas sociales (no institucionalizadas) que tienen lugar en los tiempos de la transmediación y la cDI. Los hallazgos de este trabajo permiten afirmar que este tipo de prácticas (digitales e interactivas) privilegian otras posibilidades de ser y habitar el mundo, mediante la conformación de redes y comunidades. Los niños y niñas que participaron de la investigación muestran que son capaces de construir identificaciones sociales orientadas por nuevos sistemas de intereses y necesidades. Esta conformación de identificaciones potencia un atributo central de su subjetividad: lo común como opción de vida a través de exploraciones que operan simultáneamente en el tiempo (multitasking, zapping, narrativas diacrónicas).

Aunque para los críticos esta idea de lo común en la simultaneidad del nuevo tiempo puede ser más bien un síntoma de homogeneización, consumismo y banalización, es importante indicar que tanto los espacios como los tiempos de la cDI están atravesados por tensiones entre la totalización y la singularidad, y entre la adhesión y la diferencia. Los niños y niñas experimentan estas tensiones desde que ingresan en este ecosistema comunicacional. No obstante, la dimensión sensible, ética y cognitiva que van cristalizando en su propio proceso de subjetivación, hace que produzcan sistemas de significados en y a través de la lógica de las redes y las comunidades, dislocando los tiempos y espacios institucionales.

El segundo aspecto destacado por Lazzarato (2006), que contribuye a explicar el carácter interactivo de la subjetividad, está relacionado con el concepto de polifonía de voces, categoría analítica planteada por el pensador soviético Mijail Bajtin (1997). Mientras que el régimen del signo era el culto a la verdad en occidente (auspiciado por el estructuralismo lingüístico), hacia la mitad del siglo xx Bajtin introdujo otras formas de análisis de los enunciados, observando la vida cotidiana, la experiencia cultural y sus implicaciones en la relación yo-otro. Se trata de un campo de pensamiento que vincula ética, estética y filosofía ${ }^{13}$.

\footnotetext{
${ }^{13}$ Con las dificultades que presenta el acercamiento a una obra fragmentada que fue producida en diferentes momentos bajo distintas circunstancias, al parecer peligrosas y difíciles -razón por la cual algunos de sus exégetas afirman que varios de sus trabajos fueron firmados por Boloshinov y Medvedev-, para efectos de este trabajo las alusiones empleadas están basadas en sus tesis más difundidas, pero especialmente aquellas que han sido base para nutrir los planteamientos de la filosofía del pensamiento menor y los conceptos de acontecimiento, polifonía y dialogismo. En particular textos como Hacia una filosofía del acto ético y Autor y héroe en la actividad estética, producidos entre 1924 y 1929, constituyen el corpus de esta aproximación.
} 
Para Bajtin (1997) el otro no es el reflejo del yo. Supone más bien la configuración de un tú con el que se construye la palabra y se crean medios para acontecer. Esto significa que la realidad del ser humano, comprendida como un conjunto de circunstancias temporales y espaciales que conllevan a la necesaria exploración del mundo, hace posible la experiencia. No obstante, se trata de aquella experiencia cuya fuente de significado y afectación se encuentra en el ser del otro. Esta relación con el otro no es armoniosa, no pretende crear subsunciones ni consensos. Lo que subyace a todo encuentro entre el yo y el otro son puntos de vista que se incorporan al acontecimiento y que implican consecuencias ${ }^{14}$.

Bajo este escenario de alteridad que se evidencia de estas ideas, Bajtin ratifica que el otro es incorporado como un actor necesario en la existencia del yo. Por esta razón adquiere gran valor en su teoría la construcción de la pluralidad de agentes del discurso como parte de lo que denominó acto ético. Para tal efecto, metáforas como dialogía, heteroglosia y arquitectónica adquieren en sus planteamientos las bases más sobresalientes para desplegar la noción polifonía en tanto concierto de voces. Esta polifonía implica una articulación fecunda entre sujetos, dando lugar no solo a la subjetividad, sino a formas de intersubjetividad humana. Esta incluye ámbitos mucho más exigentes de lo humano y lo social, como el carácter dialógico y colectivo del acontecimiento como medio para el reconocimiento del otro.

Esta filosofía moral que vuelve sobre los cimientos de una auténtica ontología, encuentra en la idea de responsabilidad del acto ético y de la otredad las bases para su despliegue conceptual y práctico. Bajtin (1997), en lugar de recurrir a la razón del ego solipsista, la perfección de la idea o la lucha de contrarios como las piezas determinantes en la constitución del sujeto, descubre en el acto procedente de la palabra entretejida entre el yo y el otro el principio de la construcción de la intersubjetividad. Así, la figura red de relaciones, en el contexto de lo que denominó arquitectónica de las formas del sentido, contribuye a una mejor comprensión de la noción «polifonía de voces».

\footnotetext{
${ }^{14}$ Aquí surgen dimensiones de lo humano que, para Bajtin, están ligadas al reflejo estético de la vida, el cual se extiende a otros planos, más allá de la propia individualidad. «El reflejo estético de la vida viva no es por principio el autorreflejo de la vida en movimiento, en su vitalidad real, sino que presupone a otro sujeto de la empatía, que se encuentra en la posición externa, exotópica (...)» (Bajtin, 1997, pp. 22-23).
} 
Para Bajtin (1997) el mundo de la experiencia es aquel en el que tienen lugar el acontecimiento y el acto ético, esto es, un mundo que se rige por la responsabilidad del otro, el cual orienta nuevas formas de auto-creación. Es en ese mundo de los humanos y del diario vivir en donde aparece lo estético, un hecho que transcurre en la práctica social, cuyo mayor atributo es su inestabilidad y la presencia indisoluble de una alteridad sin límites. Al parecer, el acto original de la comunicación, según Bajtin, está en la estética (particularmente en la literatura) y en sus hechos. Se trata de un entramado de significaciones en el que la realidad humana está presente, solo que bajo formas alteradas.

Esta dimensión de la estética, en relación con la creación, es para los conocedores de esta obra uno de los mayores aportes de Bajtin (1997). En este caso la alteridad, asumida como un nivel responsable de la comprensión, no supone un posicionamiento pasivo del yo ni una duplicación de la vivencia del sujeto. Se trata más bien de una transferencia de la vida a una esfera completamente diferente y desconocida de valores. Esta exploración es anudada por Bajtin a través de la relación entre el autor y el personaje en la actividad estética. Lo que produce esta relación (autor/personaje) ${ }^{15}$ es una transformación sin coartada del propio discurso, que se refleja inevitablemente en la estructura de la obra. De este modo, Bajtin propone transitar de una estética de la creación a una estética filosófica que problematiza lo humano mediante la palabra y la idea de un punto final, pero no definitivo ${ }^{16}$.

Tanto las nociones de agenciamiento (en las temporalidades de las redes y las comunidades de la cultura visual, la transmediación y la CDI) como la propensión a una polifonía de voces que surge de las búsquedas de sentido

${ }^{15}$ En el análisis que realiza Bajtin a la obra de Dostoievski, destaca que el personaje puede ser un ser repugnante que exhibe sus bajezas en lo que denomina el subsuelo de la realidad. Sin embargo, es justo en esa capacidad de exponer lo humano donde adquiere gran valoración la obra literaria. Es en la plasticidad del personaje y su propensión a transformarse, en donde hace apertura una relación particular con el lector, pues se producen confrontaciones y autodefiniciones inacabadas en las que el sujeto puede interpelarse. El asunto llega a tal nivel, que el héroe también se vuelve ambiguo e imperceptible. Ver Bajtin, 1988, citado por Ponzio, 1997.

${ }^{16} \mathrm{El}$ autor $\mathrm{y}$ el héroe se encuentran en la vida, entablan relaciones puramente vitales, de orden cognoscitivo y ético, luchan uno con otro, y este acontecer de su vida, de la intensa y seria relación y de la lucha se plasma en un todo artístico en forma de una relación arquitectónicamente estable, pero dinámicamente viva en cuanto a forma y contenido, entre autor y héroe, relación sumamente importante para la comprensión de la vida de una obra. (Bajtin, 1997, p. 105). 
de los sujetos, hacen posible que el yo (múltiple) transite a un yo colectivo que se construye con los otros. El sujeto comunicativo e hipermedial halla explicación a su existencia a partir de los encuentros y desencuentros con otros y no solo a partir de la exaltación de su yo. La cDi posibilita el encuentro y la heteroglosia a la que refiere Bajtin, a partir de las temporalidades que los sujetos reinventan mediante la interactividad.

La interactividad solo es posible mediante la polifonía de voces. En la CDI la interactividad pasa por diversos niveles. El sujeto interactúa con objetos, interfaces, contenidos, pero también con otros sujetos, grupos y comunidades. Más allá de la interacción en función del placer de ver (lo que en otros espacios es prohibido), los sujetos descubren en las temporalidades que inventan, opciones de ser y habitar el mundo de diversas maneras. Por tal motivo, la ficcionalización del yo múltiple se convierte ahora en estética del propio yo, pero también en la responsabilidad de un tú, quien se convierte en su horizonte. Este escenario abre nuevas opciones a la participación plurilingüe y exotópica. Sin embargo, las bases de este acontecimiento se encuentran en la valoración de la diferencia y la singularidad como máxima fortaleza de la acción colectiva. 
[101]

TERCERA PARTE

OTRAS EDUCACIONES Y PEDAGOGÍAS 


\section{EDUCAR EN EL ACONTECIMIENTO}

En la introducción de este trabajo se expuso la necesidad de atender a ciertos desafíos en la educación, a partir de dos grandes realidades: la estructuración de un sistema educativo, orientado por un eidos (una teleología descontextualizada producida por unos para que sea ejecutada por otros), y la emergencia de nuevas subjetividades en los niños y niñas que participan de la nueva cultura visual, las transmediaciones y la cDI. Esta segunda realidad, núcleo de esta investigación, indica que existe un divorcio evidente entre la cultura de los niños y niñas fuera de la escuela (cultura popular y cultura digital) y la cultura escolar, que aún persiste en la fabricación de una subjetividad moderna (en singular) a través de diversos discursos, prácticas y estrategias.

La escuela moderna, por la vía del buen encauzamiento (Foucault, 2005), fomentó la vigilancia jerárquica, la sanción normalizadora y el examen como mecanismos indispensables para la modelación de las mentes y los cuerpos de los individuos. Producto de este contundente modelo, prototípico de la modernidad, los sujetos que han pasado por la escuela han ingresado en una órbita de humillaciones selectivas, marcado individualismo y cierto conformismo frente a las estructuras sociales, que terminan por desactivarlos en relación con la conquista de opciones de vida dignas (colectivas y públicas). El éxito de estas instituciones radica en la regulación de los tiempos y los espacios, asunto que se expresa en rituales disciplinarios, rutinas, mediciones y una minuciosa ubicación de los cuerpos en espacios cerrados y jerarquizados (Varela, 1995). 
No obstante, algo que se ha logrado constatar con este estudio es que los niños y niñas participan de estas culturas, construyen mecanismos para mantenerse en los sistemas institucionales y cotidianos, manejan con relativa táctica las exigencias de cada uno y operan de manera estratégica frente a las intenciones de las teleologías escolares. Terminan efectuando, además, un acuerdo tácito al que se le podría llamar contrato didáctico: los estudiantes hacen de cuenta que aprenden; y los profesores hacen de cuenta que les enseñan. Bajo el esquema del contrato responden a las exigencias del mundo adulto-céntrico. Sin embargo, sus necesidades e intereses están centrados en otros temas y problemas del mundo de la vida.

Este panorama permite plantear que las prioridades de una educación capaz de dislocar las fuerzas de disciplinamiento y control de la institución escolar, deben concentrarse en tres prioridades: vivir sin humillaciones; favorecer el dialogismo y la diferencia como posibilidad de acción colectiva; y articular lo ético y lo estético en torno a la creación y la liberación. Por supuesto que esta formulación, además de atrevida, puede ser considerada ingenua, en la medida en que la escuela moderna lleva más de doscientos años de funcionamiento y la mayoría de sectores de la sociedad está de acuerdo con sus objetivos y estrategias. Para algunos, no se avizora una crisis en su actual estructura: las exigencias de la geopolítica contemporánea y del actual modelo económico hacen inexorable su sostenimiento.

Sin embargo, lo que muestra este estudio es que las expresiones de nuevas subjetividades hacen parte de un movimiento mucho más amplio que implica nuevas formas de ser sujetos, otras maneras de estar juntos, diversos medios para habitar espacios glocales (desterritorializados), ingeniosos mecanismos para actuar en temporalidades plurales y formas divergentes de actuar en red y en comunidad.

Académicos, activistas y otros actores sociales han llamado a este movimiento posmodernidad, era del vacío, modernidad líquida y sociedad informacional, entre otras denominaciones. Más allá de las preferencias intelectuales, y reconociendo lo que han significado para los niños y niñas en Colombia las complejas transiciones, se puede concluir que este cambio de época implica la presencia del acontecimiento en la vida socio-cultural, política y económica de algunos colombianos, especialmente de estos sujetos. 
No solo se trata de la presencia de otro tipo de sujetos a partir de nuevas formas de comunicación y cultura. Se trata de la sedimentación de otra posibilidad (lo virtual, la potencia, los agenciamientos) de ser sujetos y sociedad, convirtiendo lo colectivo en una opción distinta a la masa y la esencia (propios del proyecto de la modernidad). Esta opción de pensar y actuar colectiva y cooperativamente puede favorecer la creación. La creación es la base no solo de la transformación, sino de la liberación (Freire, 2004). Por esta razón, la escuela debe ser repensada: el tiempo de la instrucción y el disciplinamiento se está agotando. Su reconfiguración es posible si se parte del reconocimiento del acontecimiento, en clave de creación y liberación, como condición para construir un tipo de educación (es) que favorezca mundos posibles.

La filosofía del acontecimiento plantea que los sujetos contemporáneos, al estar incorporados en un universo mosaico mediante nuevas formas de razonamiento, producen otros agenciamientos de enunciación. Lo más importante de estas prácticas es que la percepción y la inteligencia común se convierten en sus principales modos de constitución. Lo común no supone unidad ni totalidad, sino más bien una nueva forma de disponerse en el mundo como mónadas. Esto implica desligarse de las entidades masivas y compactas, actuar como singularidad y multiplicidad, así como decidir sobre la base de creencias, deseos, voluntades e inteligencias colectivas ${ }^{1}$.

Volviendo a la obra de Bajtin (1997), se puede señalar que el sujeto en proceso de transformación se encuentra frente a una metamorfosis evidente dada la emergencia de una nueva concepción del mundo como arquitectónica, esto es, como un escenario de la acción en el que fluyen relaciones entre posibles. Dichas relaciones, caracterizadas por su dialogismo, no son de carácter lingüístico. Son polifónicas y están orientadas por el pathos, una dimensión de lo humano en la que emoción, juicios de valor y expresión constituyen la unidad viviente del enunciado. Esta es la base de la creación, el culmen de una existencia en la que el otro es referente, pero también frontera y diferencia.

\footnotetext{
I En la filosofía del acontecimiento del siglo xXI, cada mónada es un universo virtual, un mundo posible, y los mundos posibles se comunican entre ellos: «(...) pasamos de la armonía preestablecida a la composición polifónica (según otra metáfora musical que reencontramos en Bajtin), de un proceso de organización trascendente a un proceso de constitución inmanente» (Lazzarato, 2006, p. 54).
} 
Este sujeto del acto ético se convierte así en creador, no solo como artífice en la construcción de una estética de su propia vida (Foucault, 1991), sino como protagonista de una poética social. A través de ésta explora el afuera, apelando a metáforas y formas de irrupción del enunciado en el que se vuelve testigo de sí mismo, crea nexos con personajes, confronta puntos de vista con el (lo) otro, que no es su proyección sino más bien su diferencia. El sujeto del acontecimiento se constituye también en la conversación y en su propia capacidad para captar las palabras a través de una captura de capturas y una posesión de posesiones (Bajtin, 1997). En la palabra y en la configuración del enunciado, la propia expresividad parte de la expresividad del otro, solo que como posiciones inacabadas, diálogo interminable, punto final no culminado.

El acontecimiento en la filosofía del pensamiento menor implica la construcción de posibles. Esto significa que no parte de la objetivación de la realidad a través de teorías o gramáticas canónicas, generalmente relacionadas con la gestión de la vida² ${ }^{2}$ Se trata más bien de un proceso de co-efectuación entre mónadas, en el que la red de relaciones promovida por un dialogismo que contrapone puntos de vista, promueve cartografías de singularidades que son siempre distributivas, pluralistas y provisionales. Esta política de la multiplicidad no podrá realizarse sin una fuerte participación en las culturas y en los lenguajes de los demás, como una filosofía de la acción responsable. Tampoco será posible sin la presencia de conjunciones y disyunciones de flujos, esto es, una aprehensión de aprehensiones y una captura de capturas que no termina.

Comprendido el acontecimiento como algo que puede ser creado en el orden de lo posible, la formulación de criterios en torno a otra(s) educación(es), implica tener en cuenta, al menos, tres aspectos clave:

- La construcción de una educación convergente: capaz de articular niveles y dimensiones de la vida, que son fundamentales en aquellos acontecimientos de los niños, y niñas con los que construyen su subjetividad. Se trata inicialmente de tres niveles de articulación: cultura escolar-cultura popular-cultura digital; aprendizaje invisible y aprendizajes formales; y acción emocional/persuasiva y acción racional-reflexiva.

\footnotetext{
${ }^{2}$ Al respecto, es importante no olvidar las relaciones entre saber y verdad, y saber y poder, como formas ilustradas de la administración de la vida por la vía de los sistemas de conocimiento, según Foucault (2007).
} 
- La formulación de la pedagogía de la presencia: es una perspectiva centrada en el aprendizaje capaz de fomentar el tránsito de la administración de la representación de los sistemas de conocimiento (expresados en el currículo y los dispositivos escolares) y el aplazamiento del presente, a la producción de presencia (expresada en acontecimientos, polifonía de voces y mundos posibles) como una pedagogía de la praxis que favorece la liberación. Su base está en los modos de funcionamiento de las simulaciones y en las lógicas de producción de la experiencia estética.

- Las (hiper) mediaciones pedagógicas: se trata de formular criterios para la puesta en marcha de prácticas pedagógicas que incluyan aspectos como el replanteamiento de contenidos, la presencia de otros dispositivos pedagógicos, la gestión divergente de espacios y tiempos, trabajo por redes y comunidades, gestión y distribución de contenidos, creación y experiencia estética, y acción colectiva.

\section{EDUCACIÓN CONVERGENTE}

La formulación de una perspectiva educativa que parta de los fenómenos analizados hasta el momento no es una tarea simple dada la complejidad de los procesos, actores, sectores e instituciones involucrados en la formación de los niños y niñas y en su escolarización. Las condiciones contemporáneas en las que tiene lugar la producción de la nueva subjetividad infantil hacen necesario que la educación deba ser repensada a partir de la recuperación de principios ya conocidos, así como de perspectivas renovadoras. Se trata de un esfuerzo por re-contextualizar nociones asociadas con la liberación y el autoaprendizaje (Freire, 1973) en diálogo con una propuesta de educación convergente, capaz de articular no solo formatos, interfaces y medios, sino lenguajes, saberes y procesos de creación.

La convergencia en educación planteada aquí parte de las nuevas realidades de los niños y niñas. Va más allá del uso de los medios y las tecnologías para enseñar contenidos. No necesariamente supone la aplicación de la convergencia digital al proceso educativo. $\mathrm{Y}$, aunque recupera elementos de la perspectiva emancipadora de las pedagogías críticas, no pretende replicar las estrategias referidas a la crítica de los medios y la denuncia de las hege- 
monías. A partir del recorrido presentado, la educación convergente plantea como propósito la reconfiguración de la educación, la pedagogía y la práctica pedagógica a partir de articulaciones e hibridaciones en tres niveles relacionales de la subjetividad infantil así:

- Cultura popular, cultura escolar y cultura digital.

- Aprendizaje invisible y aprendizajes formales.

- Acción emocional-persuasiva y acción racional-reflexiva.

Para desarrollar cada uno de estos tres niveles relacionales alrededor de una educación convergente a tono con las expresiones de la nueva subjetividad infantil, conviene recordar que la escuela es una institución moderna, creada para el cumplimiento de propósitos específicos: disciplinar cuerpos y mentes por la vía de la institucionalización; enseñar contenidos organizados mediante planes de estudio canónicos y enciclopédicos; fomentar los valores del Estado nacional bajo la persistencia de rituales militares (izar la bandera, formar en fila, marchar, acoger con solemnidad el himno nacional); centrar sus actividades en la enseñanza a través de diversos dispositivos; aplazar el presente del sujeto y profundizar la retórica de su preparación para el futuro.

Estos propósitos cuentan con tres elementos clave: el docente, el texto escolar y el examen. Para la escuela moderna, el docente es el portador del conocimiento, el que administra las dosis de contenidos que deben ser suministrados y quien determina las buenas y malas acciones de los alumnos mediante sofisticados mecanismos de moralización. De otra parte, el texto escolar es el instrumento que, por excelencia, orienta y determina lo que se debe enseñar y aprender. Sus referentes son cuidadosamente administrados por el docente y se convierten en una teleología que eventualmente puede ser complementada mediante la consulta o la exposición.

Finalmente, el examen es la evidencia del aprendizaje y el instrumento que hace posible el control social en el mundo escolar. Ante la distancia entre los intereses y necesidades de los sujetos y los contenidos enseñados, el examen es el dispositivo más importante para impulsar a la fuerza la vigencia de los contenidos (generalmente diseñados por corporaciones privadas de la industria editorial) y su validación mediante la medición de información acumulada y algunos procedimientos que suelen equipararse a habilidades y competencias. Vale señalar además que el examen se convierte en expediente 
y su uso institucional tiende a convertirse en una suerte de antecedente judicial para los potenciales infractores.

En medio de este escenario, los actores involucrados participan de un simulacro. Mientras que algunos hacen creer que enseñan, otros presentan exámenes para intentar su aprobación y, de este modo, cumplir con las exigencias institucionales que le permitirán aprobar. Muchos niños y niñas aprenden a habitar este espacio, el cual, además de anclado en el tiempo, no logra reconocer sus sistemas de intereses y necesidades en el tiempo presente. Sin embargo, esta permanencia en la escuela, aunque no cobre mucho sentido en lo académico, se resignifica en lo social y lo cultural, pues, en medio del ambiente de homogeneización y disciplinamiento, se filtran tácticas y estratagemas a través de espacios y tiempos subterráneos, en los que circulan otros referentes de la vida.

Estas consideraciones no pretenden fomentar la desaparición de la escuela ni buscan culpabilizar a los profesores. Es claro que, en Colombia, las reformas educativas no han logrado responder al divorcio entre el mundo de la vida de los niños y niñas y la reafirmación de una escuela que promueve rituales disciplinarios y la reproducción social. Sin embargo, también es importante reconocer que para muchos niños y niñas, la escuela es una de las pocas opciones que tienen para salirle al paso al conflicto social y armado en muchas regiones de Colombia. También es, en algunos casos, un escenario de protección frente a las condiciones de maltrato y vida precaria que los acompañan desde su nacimiento.

Repensar la escuela implica convertirla en un escenario que propicia aprendizajes para la vida a partir del diálogo de saberes, la colaboración y el fomento de la inteligencia colectiva. Implica modificar su estructura (asignaturas basadas en contenidos, regulación taxativa de tiempos y espacios, texto escolar como fuente de conocimiento, profesores que enseñan) mediante la convergencia de culturas, el reconocimiento de otras formas de aprendizaje (no escolares) y la incorporación de factores emocionales-persuasivos en la práctica pedagógica. La base de esta propuesta es el reconocimiento de las nuevas subjetividades aquí exploradas y la existencia de un ecosistema comunicacional que, en medio de los rezagos estructurales y brechas de una sociedad moderno-colonial como Colombia, se constituye en una oportunidad para producir acontecimientos. 


\section{CONVERGENCIA ENTRE CULTURA POPULAR, CULTURA DIGITAL Y CULTURA ESCOLAR}

Las nociones de cultura, como se pudo constatar en el primer apartado de este trabajo, son prolíficas y remiten generalmente a los debates sobre los sistemas de significado compartidos por grupos humanos (Williams, 2008). Sin embargo en el funcionamiento de la escuela moderna, la cultura que se ha sedimentado ha adquirido expresiones complejas en la medida en que los saberes y prácticas que predominan en el mundo escolar no han logrado dialogar con los intereses y necesidades de los niños y niñas, quienes son en últimas los que le dan sentido a su quehacer. Uno de los elementos que mejor explica este fenómeno es la noción de alumno, la cual da cuenta del predominio de un rol en un espacio social. Detrás de la designación de alumno intencionalmente opera el desconocimiento de la condición de sujetos, esto es, niños y niñas, integrantes de una familia, miembros de redes de amigos, partícipes de comunidades.

Los rituales escolares, como ya se ha señalado, reafirman un telos institucional que ha entrado en crisis. A juicio de Huergo (2010), las instituciones - particularmente la escuela- son fabricadas y sobreviven a partir de la invisibilidad de las urdimbres simbólicas y de las significaciones imaginarias que, paradójicamente, autorizan su visualización. Generalmente, su funcionamiento está basado en la ley y los principios universales. Por esta razón, una de sus funciones centrales es la contención de las diferencias, la constricción de la experiencia individual y social, y la administración de lo prohibido y lo permitido.

No obstante, el liberalismo ha señalado a lo largo de los últimos doscientos años que estas formas de regulación son imprescindibles para cualquier sociedad. Para algunas corrientes procedentes del realismo político (particularmente originadas en el clásico Leviatán de Hobbes, 2007) sin un Estado fuerte no hay más remedio que el caos y el estado de guerra. Para otras, como la inaugurada por Kant, el hombre es tan racional que puede implementar conjuntamente formas de entendimiento para favorecer la paz perpetua.

Otras más recientes, justifican las instituciones porque son las únicas que pueden garantizar y restituir los derechos, asunto que en la perspectiva de Rawls (2006), por ejemplo, exige de organizaciones justas y al servicio de la sociedad. Finalmente, perspectivas mucho más cercanas a este tiempo 
transicional, como las de Amartya Sen (2000), introducen la importancia de las capacidades y oportunidades a través de las instituciones como los medios más efectivos para garantizar bienestar y dignidad.

Aunque estos debates son mucho más profundos, es importante precisar que no se trata de prescindir de la cultura institucional per se, dadas las subjetividades emergentes de las sociedades contemporáneas. No se puede negar que históricamente la institución ha sido el mecanismo más cercano al aseguramiento de los derechos y el medio para garantizar las libertades en las sociedades occidentales y occidentalizadas. Sin embargo, la escuela es la institución más crítica de este modelo porque su función cada vez es más ambigua: garantizar derechos, pero regular y controlar. Por esta razón, una educación convergente requiere, en primer lugar, abrir la escuela y des-estructurar sus lógicas de funcionamiento. Esto supone interpelar sus rituales, modificar aquellos que ya no sirven y fomentar un diálogo abierto con otras formas simbólicas que son fundamentales en la vida de los niños y niñas.

Al respecto es importante tener en cuenta, a través de lo señalado a lo largo de este trabajo, que las infancias hacen parte de un espacio-tiempo distinto al de la escuela y que sus experiencias, además de estar relacionadas con diversos sucesos como el conflicto y la recomposición de las estructuras familiares, están atravesadas por la comunicación, el consumo y la estética. La expresión de sus subjetividades muestra riquezas simbólicas y potencialidades para actuar en red bajo nuevas formas de participación. Aunque este no es un proceso que se ha logrado simplemente por estar en el mundo de la calle o en las redes sociales, los hallazgos de la parte dos de este trabajo muestran el valor de otros referentes, de otras gramáticas para visibilizar su existencia y de otras interacciones que hacen posible explorar y aprender.

La cultura popular es una categoría ampliamente trabajada por diversos autores. Para Martín-Barbero (2003) las culturas populares de América Latina están enmarcadas en lo que denominó sociedades-encrucijada, lo que implica la existencia de subdesarrollos acelerados y modernizaciones compulsivas. Esto supone que las experiencias enmarcadas en el barrio, el parque, la biblioteca, el museo, e incluso en el centro comercial, hacen parte de las matrices culturales y el mundo de sensibilidades y socialidades que también otorgan sentido a la existencia de estos sujetos. 
En estos espacios sociales existen problemáticas y expresiones de un mundo paradójico que entremezcla desigualdades, exclusiones, violencias e injusticias. Pero también, se trata de escenarios en los que surgen las invenciones de la cotidianidad (De Certeau, 2007), los recursos más creativos para responder a estas circunstancias de inequidad y los lugares que dotan de sentido a ciudadanos que experimentan. La ciudad es el flujo de las culturas populares y su dinamismo estimula constantes reconfiguraciones. Relatos y prácticas que involucran lenguajes y saberes hacen posible que los sujetos se vinculen, se excluyan o descubran cómo volverse parte de las redes de sentido que allí se tejen.

Las culturas populares implican medios y mediaciones, según Martín Barbero (2003). Esto significa que en la construcción de las identificaciones sociales no son los referentes del Estado nación los que siempre predominan, sino también los formatos y contenidos enmarcados en las industrias del entretenimiento y el mercado. En el estudio de Martín-Barbero, las mediaciones más prominentes en la construcción de lo popular a lo largo del siglo xx en la región fueron: el cine como expresión del pueblo; el radio-teatro y la emoción radial; las músicas que se conformaron alrededor de diversas tradiciones culturales; la prensa popular de masas $^{3}$. Aunque el capitalismo maneja estas ofertas, los usos y apropiaciones que hacen diversas personas hacen posibles producciones culturales y significados compartidos, esto es, múltiples fuentes de nuevas subjetividades.

En las actuales circunstancias, las mediaciones han variado y se cruzan con las nuevas formas de comunicación en la cultura. Como se observó en la primera parte de este trabajo, las televisiones y filmografías que han acompañado a la actual generación de niños y niñas dan cuenta de una cultura popular que se funde con transmediaciones y prácticas comunicativas mediante la CDI. Aunque no es intención introducir los debates alusivos a la cultura digital (adoptados con gran optimismo por entidades del Estado y corporaciones transnacionales) ${ }^{4}$, vale reafirmar que tanto las alusiones a la cibercultura

\footnotetext{
${ }^{3}$ Estos elementos son cuidadosamente analizados por el profesor Martín Barbero en su obra De los medios a las mediaciones (2003), referenciada en capítulos anteriores y base sustancial para la formulación de la categoría hipermediaciones (Scolari, 2008). ${ }^{4}$ Ejemplo de este entusiasmo es la política Vive Digital del Ministerio de las TIC en Colombia y el estímulo económico de la compañía Telefónica a eventos que promueven el uso y la democratización de las tecnologías digitales como el Campus Party.
} 
como a la CDI refieren a la existencia de entornos nuevos que están haciendo posible la cristalización de una cultura llamada digital.

La cultura digital es un fenómeno socio-cultural, político y económico que introduce espacios y tiempos de flujos y conexiones en los que circulan mensajes, formatos, textos y obras cuya principal característica es una suerte de tensión entre mercado y libre expresión a través de medios electrónicos. Esto explica por qué es una categoría adoptada por aquellos que están interesados en la acumulación capitalista y otros que han encontrado opciones para visibilizarse, interactuar, participar y emprender proyectos con intereses colectivos, estéticos y hasta anti-hegemónicos.

Los niños y niñas han participado desde muy temprano en este ecosistema comunicacional, de modo que hacen parte de una mutación que vincula cultura popular y cultura digital. Los relatos y producciones culturales ahora circulan por los espacios de la cultura digital. Sin embargo, muchos de los contenidos que le dan sentido a la cultura digital están emparentados con la cultura popular. Esto significa que los niños y niñas son usuarios y gestionan lenguajes y saberes en estas interfaces, las cuales muestran en la práctica múltiples convergencias relacionadas con medios, formatos, narrativas y ficciones que propician otras formas de subjetivación.

La articulación propuesta aquí implica introducir la cultura popular y digital en la cultura escolar a través de una educación convergente que se centre en los niños y niñas. Para tal efecto, se requiere construir currículos capaces de articular los intereses y saberes de las tres culturas. Si la cultura escolar busca fomentar conocimientos a través de las gramáticas de las disciplinas (orientadas por el eidos de la política educativa y los estándares curriculares), debe crear relaciones entre estos contenidos con contextos problematizadores de la cultura popular y de la cultura digital que viven y exploran los niños y niñas.

Por esta razón es necesario indagar sistemáticamente, sin invadir su intimidad, sus intereses y necesidades. Esto implica desactivar las fronteras disciplinares de las asignaturas para identificar problemas que articulen las áreas del conocimiento mediante la interdisciplinariedad. La pedagogía de proyectos pedagógicos podrá ser útil para resolver procedimentalmente esta exigencia. Sin embargo, no se trata de replicar los proyectos de aula o los 
centros de interés de la Escuela Activa. La articulación propuesta supone, luego de identificar los intereses y las necesidades del grupo de niños y niñas, proponer contextos populares-digitales en los que sea posible poner en escena los saberes (disciplinares, populares y digitales), los cuales deben responder a problemas concretos.

Esta convergencia replantea varios elementos que han sido invariantes culturales e institucionales en el contexto escolar de los últimos dos siglos, entre ellos el imaginario del saber. En la actualidad ya no es posible darle prevalencia únicamente al sistema de saber canónico, comprendido como aquel que el profesor posee o que es transmitido mediante textos escolares. Las fuentes de conocimiento ya no se encuentran únicamente en estos dos referentes (profesor y libro). Los niños y niñas han descubierto que es posible acceder a la información a través de diversos medios y dispositivos. La lógica de enseñar asignaturas, exigir tareas escolares y evaluar es una cadena que perdió sentido para el aprendizaje.

Cuando se trabaja por problemas de manera convergente, los niños y niñas deben concentrarse en prácticas que favorezcan el descubrimiento, la abducción y la comprensión del fenómeno en cuestión ${ }^{5}$. La dispersión de asignaturas en tiempos institucionales fragmentados inhibe estas posibilidades. Se requiere, por lo tanto, de serias modificaciones al imaginario del saber, especialmente porque niños y niñas difícilmente responden a las lógicas del transmisionismo. Las formas de razonamiento hipermediales e interactivas,

\footnotetext{
${ }^{5}$ La abducción es un proceso analizado recientemente por varios autores, basados en las prácticas indiciarias evidenciadas en relatos como los de la obra Sherlock Holmes (Arthur Conan Doyle) y el llamado método morelliano (frecuentemente discutido por los historiadores del arte de la escuela italiana). Particularmente Carlo Ginzburg (2008), en un ensayo en el que explora estos casos, plantea la abducción como una manera de leer, según la cual las diversas partes de una situación o un texto se convierten en pistas para descubrir sentidos. Un buen lector aprende a interpretar abductivamente. Por ello, su modo de leer privilegia la identificación de piezas sueltas que deben ordenarse, así como la formulación de relaciones entre textos y contextos para hallar explicaciones nuevas. Además de Sherlock Holmes, bien pueden reconocerse otros personajes que han incursionado por esta forma divergente de razonamiento como Dupin (el detective de Edgar Allan Poe) y el hermano William de Humberto Eco en El Nombre de la Rosa. En estas historias se evidencia que el significado de una palabra o de una expresión no puede entenderse de manera aislada. El buen detective comprende que esas pistas halladas deberán llevarlo a otras informaciones que le harán relacionar la escena del crimen, las acciones y los implicados. Otro aspecto clave de la abducción es que las informaciones o elementos insignificantes a simple vista, pueden cobrar un valor estratégico para resolver el caso.
} 
identificadas en el trabajo de campo de este estudio, muestran que su manera de producir sentido está asociada a usos divergentes de sistemas simbólicos en interfaces gráficas, interacción permanente mediante formas simples y espontáneas de participación y cierta propensión a re-crear piezas comunicativas en contextos de postproducción y coproducción.

Finalmente, conviene recordar tres principios de Freire (2005) que resultan útiles para comprender esta propuesta de convergencia. Al introducir la educación para la liberación como una opción distinta a la educación bancaria y al predominio de las formas de dominación que han sido incorporados mediante la educación, Freire precisaba: los estudiantes deben ser partícipes activos de su propio aprendizaje; las experiencias de aprendizaje deben resultar significativas para que éstos continúen aprendiendo por su cuenta; el aprendizaje debe estar orientado por un sentido crítico. Al respecto Grundy (1994) complementa que no solo se trata de situar el aprendizaje en el contexto del estudiante, sino de promover procesos relacionales, que estimulen diálogos, co-existencias y tratamiento de problemas.

Esto significa que la educación convergente no solo supone imaginación pedagógica para vincular los mundos que, hasta ahora, han tenido un divorcio evidente en la formación de los niños y niñas. Se trata de una educación para la liberación y la esperanza que favorezca la praxis como aquello que enlaza reflexión y acción. Una praxis que ponga en contexto las contradicciones y las posibilidades. Una praxis que promueva no solo la comprensión del mundo, sino la transformación. La transformación ya no es algo que el niño puede realizar en el futuro, sino una posibilidad que se basa en la acción colectiva, el aprendizaje colaborativo y la creación de su propio presente.

\section{CONVERGENCIA ENTRE APRENDIZAJE INVISIBLE Y CONOCIMIENTOS FORMALES}

Esta segunda convergencia plantea como punto de partida una hipótesis que no ha sido reconocida por la pedagogía convencional y que, una vez más, parte del agotamiento de la escuela moderna. Se trata de la existencia del aprendizaje invisible (Cobo y Moravec, 2010), un tipo de aprendizaje que tiene lugar en espacios no institucionales y que ocurre a lo largo de la vida de las personas. Puede ser entendido también como un conjunto de capitales culturales que son adquiridos mediante experiencias comunicativas ligadas a la era «eco-info-bio-nano-cogno», la cual está asociada con culturas e inte- 
ligencias que se movilizan en los espacios transaccionales de las tecnologías digitales en red $^{6}$.

El aprendizaje invisible sugiere también nuevas prácticas sociales y educativas. En estas las tecnologías de información y comunicación (TIC) ocupan un lugar estratégico, pues se convierten en la mediación necesaria para la conquista de habilidades fundamentales de cara a las complejidades de la globalización. Para Cobo y Moravec, estas habilidades incluyen un amplio marco de competencias, conocimientos y destrezas que, según el contexto, podrán ser adoptadas para favorecer el acceso al trabajo, impulsar la formación de «agentes del conocimiento» y ampliar las dimensiones del aprendizaje tradicional (2010, p. 24)

Aunque el tono pragmático de los alcances del aprendizaje invisible parezcan una respuesta mágica a los grandes problemas de la escuela moderna, vale destacar su fuerza como categoría analítica para comprender el escenario contemporáneo y las potencialidades de lo que pueden hacer los sujetos con las tecnologías digitales como acción social e interpelación a la educación convencional. $\mathrm{Al}$ respecto, vale recordar el conjunto de saberes que fueron

\footnotetext{
${ }^{6}$ Para comprender la complejidad del aprendizaje invisible, es necesario aludir a una categoría en la que se apoya: educación expandida. La educación expandida es una noción que engloba las nuevas formas de educación en el contexto de los procesos sociales y comunicacionales que ha provocado el uso de Internet. La nueva cultura digital se caracteriza por la organización en red, el trabajo colectivo, la convergencia de medios, el copyleft, etc., y es el principal escenario en el que acontece la educación no institucional. La iniciativa ZEMOS corrobora que son innumerables proyectos artísticos, científicos, comunicacionales y educativos (con rasgos culturales, sociales, digitales y audiovisuales) los que constituyen ahora la vanguardia de la educación en el siglo XXI. Estas experiencias corroboran que la educación puede suceder en cualquier momento, en cualquier lugar y no siempre dentro de los recintos de las instituciones educativas. El entorno comunicacional y digital se convierte así en una oportunidad histórica para fomentar nuevas educaciones y recuperar la reciprocidad en las formas de distribución del conocimiento. Los contenidos y las memorias del proyecto ZEMOs están disponibles en el sitio http://www.zemos98.org/eduex/spip. php?articlel64. Consulta realizada el 2 de mayo de 2012.

7 Para Cobo y Moravec (20I0, p. $4 \mathrm{I})$, los cinco postulados claves del aprendizaje invisible son: I) Las competencias no evidentes resultan invisibles en los entornos formales; 2) Las TIC se hacen invisibles; 3) Las competencias adquiridas en entornos informales son invisibles; 4) Las competencias digitales resultan invisibles; 5) Hay ciertas prácticas empleadas en la escuela/universidad que es necesario invisibilizar.
} 
identificados en las prácticas comunicativas de los niños y niñas de este estudio ${ }^{8}$.

Además de los saberes relacionados con el uso de la interfaz y las aplicaciones de la red social, los niños y niñas invitados a participar de esta investigación producen capitales culturales alrededor de formas de transmediación que articulan saberes técnicos, estéticos y sociales. Por esta razón indagan información, promueven disputas y provocaciones alrededor de temas y problemas de interés colectivo, introducen sonoridades y visualidades como referentes que movilizan emociones y afectos, y gestionan y comparten contenidos de diversa índole. De otra parte, también son capaces de producir intertextualidades mediante segmentos de textos y formatos que les permiten componer lo que buscan expresar.

Mientras más ubicuo y diverso sea el uso de las tecnologías de información y comunicación, afirman Cobo y Moravec (2010), más probable es el desarrollo de nuevas habilidades y aprendizajes que resultan invisibles o ignorados por los tradicionales instrumentos de medición del conocimiento (cuestionarios, exámenes, pruebas de selección múltiple). Esto introduce otra variable importante del aprendizaje invisible: el uso de las tecnologías digitales es transversal a la acción socio-cultural y pedagógica, por esta razón, entre más invisible sea el uso de las máquinas, el software y la red, la adquisición de capitales culturales cobra mayor sentido en el sujeto9.

Esto explica por qué es posible identificar otras formas de conocimiento en las prácticas comunicativas de los niños y niñas. Los aprendizajes invisibles se producen porque suelen estar mediados por sistemas divergentes de necesidades e intereses que no siempre coinciden con los intereses institucionales del mundo escolar. En segundo lugar, lo que se aprende está ligado a acontecimientos de la vida, deseos y emociones que tienen diversos niveles: visibilizar el yo, socializar, compartir intereses, posicionar puntos de vista, estar en red para apoyarse en los saberes de otros, utilizar contenidos para compartir y producir, reflexionar colectivamente, participar en proyectos comunes.

\footnotetext{
${ }^{8}$ Es importante recordar que en el estudio (Parte I) fueron identificados tres tipos de capitales culturales: saberes en torno a los usos y apropiaciones de la interfaz; saberes adscritos a contenidos y transmediaciones; saberes de la intertextualidad.

${ }^{9}$ Es un criterio muy importante dado que, con frecuencia, la incorporación de tecnologías en la escuela es planteada como la tabla de salvación y el instrumento que mecánicamente garantizará aprendizajes (Buckingham, 2008).
} 
Todas estas prácticas, evidenciadas en la vida cotidiana en red de los niños y niñas que participaron de este estudio, tienen un elemento común: se aprende haciendo y experimentando. Esta premisa que parece una declaración de sentido común es lo que menos ocurre en las prácticas pedagógicas de la escuela moderna. Según Moravec (2010), los individuos que participan de los cambios acelerados de la sociedad 2.0 fuera de la escuela, están frecuentemente inmersos en experiencias vitales asociadas con interconexiones y redes. Esto supone una tendencia creciente hacia la experimentación y la vinculación a proyectos colectivos. Mientras que la sociedad 3.o, mediante redes y comunidades, asume a los sujetos como knowmads $^{10}$, la escuela los considera individuos deficitarios.

La articulación entre aprendizaje invisible y conocimientos formales no es sencilla. Generalmente, los docentes utilizan ejemplos de la vida cotidiana o alusiones a las coyunturas sociales para introducir los temas de sus asignaturas. Estas relaciones son insuficientes y probablemente apelan al mundo de la vida como una suerte de caricatura para posicionar marcos explicativos planos y unidireccionales. Sin embargo, esto no quiere decir que se deba abandonar el estudio de teoremas, hechos históricos, obras literarias o fórmulas.

Si estos objetos de estudio siguen siendo enseñados sin relación alguna con el mundo (de interacciones, flujos y transmediaciones que compone este tiempo transicional) y si continúan siendo transmitidos sin mediaciones que favorezcan su traductibilidad en relación con los sistemas de necesidades e intereses de los sujetos del aprendizaje, seguirán operando como informaciones que se replican para aprobar exámenes o lograr la promoción de un nivel a otro ${ }^{11}$. Una vez más, esta situación ejemplifica la existencia del contrato didáctico enunciado anteriormente.

\footnotetext{
${ }^{10}$ Moravec introduce este neologismo, el cual combina las palabras know (conocer, saber) y nomad (nómada), las cuales dan cuenta del perfil del sujeto capaz de ser un nómada del conocimiento. «Un knowmad es alguien innovador, imaginativo, creativo, capaz de trabajar con prácticamente cualquier persona, en cualquier lugar y en cualquier momento. Un knowmad es valorado por su conocimiento personal, lo que le proporciona una ventaja competitiva con respecto a otros trabajadores» $(2010$, p. 56).

"No se trata de cuestionar la evaluación en sí misma. Sin embargo, uno de los engaños más frecuentes de la escuela moderna es asumir que el estudiante que aprueba un examen de conocimientos aprendió. Esto ha sido estudiado por psicólogos del aprendizaje de diversas maneras, quienes suelen incluir factores asociados al aprendizaje para explicar este fenómeno. Cobo y Moravec (2010) introducen la noción amnesia posevaluativa para explicar por qué resolver exámenes no es garantía de aprendizaje.
} 
La convergencia entre aprendizaje invisible y conocimientos formales implica disponer los sistemas de codificación y decodificación del saber en contextos que ofrezcan sonoridades, visualidades y composiciones entre textos escritos, imágenes, narrativas y ficciones. Las realidades de los niños y niñas requieren de estos repertorios semiótico-pedagógicos para favorecer aprendizajes. Esto supone reconocer, al decir de Martín-Barbero (2003), que si ya no se lee como antes, ni se escribe como antes, ni se ve y escucha como antes, no se conoce ni se aprende como antes. Por esta razón ya no es posible educar como antes ${ }^{12}$.

Finalmente, esta convergencia promueve el estudio de objetos de conocimientos mediante la participación, la colaboración, las alianzas voluntarias y la creación colectiva. Por esta razón, los roles de profesores y estudiantes cambian radicalmente. Se replantea la lógica de enseñar contenidos, pues convierte las lecciones, las explicaciones y la administración de las rutinas (ejercidas soberanamente en el espacio escolar) en experiencias comunicativas que pueden llegar a desterritorializarse. De manera acertada Kaplún (1987), hace más de dos décadas, planteó que una experiencia educativa y comunicativa es aquella que privilegia el intercambio, esto es, un proceso en el que los estudiantes no son simplemente oyentes o lectores sino interlocutores.

Esta nueva educación busca que los niños y niñas sean auténticos agentes del conocimiento (Meyer, 2010). Hace posible que actúen sobre su propio conocimiento, asociando lo que aprenden en espacios cerrados y abiertos (mediante la solución práctica de problemas) con la producción cultural que suelen experimentar en las interfaces de las pantallas a través de experiencias de transmediación. Por esta razón, si la expresión más sobresaliente del aprendizaje invisible es la producción promovida por aquello que ocurre fuera de la escuela, la práctica pedagógica debe fomentar ambientes para la generación, relación y transferencia de conocimientos. Los conocimientos se producen y circulan fuera de la escuela. En adelante, la labor de ésta será garantizar que estos conocimientos también pasen por el contexto escolar, procurando su experimentación colectiva y creativa.

\footnotetext{
${ }^{12}$ Para Cobo y Moravec (2010), aprender haciendo se enfoca más en cómo aprender que en el qué se aprende. Esto sugiere que las pruebas deben basarse en los procesos y resultados que se indagan cuando se busca evaluar proyectos innovadores (iQué ha ocurrido? ¿Ha ocurrido algo nuevo? ¿Algo inesperado? ¿Ha proporcionado algún beneficio? ¿Qué pueden aprender otros a partir de esta experiencia?).
} 


\section{ACCIÓN EMOCIONAL-PERSUASIVA Y ACCIÓN RACIONAL-REFLEXIVA}

Esta convergencia es, quizás, una de las más difíciles de abordar porque plantea, apoyados en los extraordinarios trabajos de Joan Ferrés (2008), una premisa: la eficacia de los procesos de enseñanza-aprendizaje está condicionada en buena medida por la eficacia comunicativa de los profesores. Además de dominar los contenidos de un área de conocimiento, el rol del profesor-comunicador contiene otras exigencias, por ejemplo comprender las formas de ser sujetos en las nuevas generaciones, identificar las arquitecturas de pensamiento de sus estudiantes y reconocer con claridad qué les emociona y les moviliza.

A juicio de Ferrés (2008), las tecnologías de información y comunicación son invenciones técnicas condicionadas y condicionantes que, en todo caso, hacen parte de complejos cambios sociales y personales producidos en el entorno cultural. Más allá de los usos educativos de las Tic (perspectiva predominante en los campos de la didáctica y la educación en tecnología), su uso social generalizado (proceso que incluye a niños y niñas) da cuenta de cinco grandes cambios: intensificación de la sensorialidad y de la concreción; incremento del dinamismo; refuerzo de las emociones primarias; potenciación del procesamiento intuitivo y sintético; y fomento de la interactividad.

Estos aspectos coinciden con varias de las expresiones identificadas en la etnografía online implementada en la segunda parte de esta investigación, al indagar las mutaciones comunicativas de los niños y niñas. Uno de los aspectos más llamativos del estudio revela que la ordenación de objetos virtuales en la interfaz de la red social conlleva la reivindicación de un yo con múltiples repertorios de expresión. Mediante esta figuración yoica proceden luego a la producción de narrativas que funden el yo y el otro a través de trayectorias y recorridos que son fomentados por itinerarios hipermediales. Esto hace posible más adelante que, mediante provocaciones y lenguajes vinculantes, los sujetos experimenten la interactividad y compartan contenidos, pero también sentimientos y emociones.

Dada la hiperestimulación sensorial y la provocación de nuevos dinamismos, asociados frecuentemente con los espacios y tiempos de la transmediación, la actividad cerebral cambia. Si hasta hace algunas décadas la actividad humana, ligada al texto escrito (lineal, de izquierda a derecha y 
estructurado) privilegiaba la reflexión, actualmente la vinculación de los sujetos a contextos pantallizados e hiperconectados prioriza la imagen como el referente fundamental para interactuar y experimentar. Este suceso implica una activación profunda del cerebro emocional (Ferrés, 2008, p. 70) ${ }^{13}$. Las emociones son las generadoras de acciones que conllevan al logro de metas, valiéndose de diversos recursos que estimulan la solución de problemas y el uso de la creatividad.

La actitud del consumidor-productor en las pantallas, según lo observado en este estudio, privilegia de manera contundente las imágenes en movimiento y fomenta un estilo de comunicación sincrónico y asincrónico, capaz de incursionar por tiempos y espacios divergentes, los cuales ponen en escena repertorios emocionales, estéticos y cognitivos. La experimentación de los niños y niñas con expresiones audiovisuales, digitales y virtuales produce emociones primarias que se derivan de la materialidad de los signos, las sonoridades, las policromías y las tonalidades. Esto hace que la inteligibilidad de los objetos de conocimiento no necesariamente pase por la vía del intelecto. La sensorialidad basta, señala Ferrés (2008).

Aunque el debate entre la estimulación de las dimensiones sensorial-emocional y racional-reflexiva en la educación tiene una larga trayectoria en los terrenos de la pedagogía, la psicología cognitiva y las neurociencias, se puede señalar que no se trata de prescindir de ninguna de las dos. Sin embargo, vale decir que la historia de la escuela moderna muestra que las prácticas pedagógicas han sido orientadas bajo presupuestos generalmente relacionados con aprendizajes amparados por el estatuto de la racionalidad, la reflexión y la actividad intelectual. La incorporación de ingeniosas formas de intimidación en la máquina escolar (Varela, 1995) ha desplazado las emociones y los deseos a la esfera de lo privado.

Los estudios sobre inteligencias múltiples e inteligencia emocional también muestran que si se producen lesiones (por accidente o por falta de estimulación) en el cerebro emocional, esto afectará notablemente la toma

\footnotetext{
${ }^{13}$ Aunque no ha sido utilizado como referente a lo largo de este trabajo, las alusiones de Ferrés a las neurociencias son útiles para respaldar este tipo de afirmaciones. Los trabajos referidos al cerebro emocional se encuentran principalmente en neurobiólogos como Mark Solms (2002), Jan Panksepp (2002) y Rita Carter (2002). En términos generales, los experimentos de laboratorio muestran que el cerebro emocional es el responsable de la actividad creativa y la movilización de acciones.
} 
de decisiones y la puesta en marcha de proyectos que requieren riesgo e innovación ${ }^{14}$. Incluso, algunos autores que han estudiado el cerebro emocional como central energética (Carter, 2002), admiten que estas características se constituyen en requisito sine qua non para solucionar problemas, movilizar acciones y favorecer la creación. En suma, el futuro de la inteligibilidad del mundo, la toma de decisiones y la producción de nuevas ideas para resolver problemas dependen en buena medida de la activación de zonas cerebrales que regulan y estimulan las emociones.

Este recorrido no solo debe servir para ver de otra manera los vínculos que los niños y niñas están generando con las pantallas en el contexto de la CDI. También sugiere muchas preguntas en torno al perfil del profesor y al tipo de práctica pedagógica que ha de fomentar la nueva educación. Para responder a estas inquietudes conviene aludir una vez más a Ferrés, quien expresa que no se trata de estigmatizar la razón, el intelecto y la reflexión. El retorno de la emoción al mundo de la escuela (por la vía de los niños y niñas más que por la iniciativa de la institución) exige de profesores capaces de educar en la frontera emocional (2008, p. 82).

Las exigencias para trabajar en esta frontera son diversas. Se destacan la modificación de los tiempos y espacios de la práctica pedagógica; el uso de nuevas fuentes de información y conocimiento (más allá del libro de texto); el estímulo a nuevas formas de razonamiento (hipermediales e interactivas) por la vía de la experimentación del acontecimiento; la generación de ambientes de aprendizaje online y offline en los que convergen temas y problemas de la vida mediados por distintos sistemas de conocimiento; $\mathrm{y}$ formas de interacción que fomenten la inteligencia colectiva.

Lo que atraviesa cada una de estas exigencias es la presencia de un profesor-comunicador que sea capaz de integrar con criterio las emociones a la

\footnotetext{
${ }^{14}$ Aunque no es interés de este trabajo introducir estos debates dadas sus limitaciones pedagógicas y comunicacionales, es importante destacar que, con el surgimiento de estas teorías en la década del noventa, se fue debilitando progresivamente el paradigma del IQ. La apertura a la existencia y el estudio de las nuevas inteligencias trajo como consecuencias cierta flexibilidad en el aprendizaje. No obstante, se trata de un modelo aún muy lejano de la escuela convencional (con excepción de los seguidores de la llamada Enseñanza para la comprensión).
} 
pedagogía. Esto significa que el profesor debe incentivar el deseo, ayudar a descubrir el placer en las actividades que requieren de esfuerzo y dedicación y transformar el objeto de deseo en objeto de conocimiento. Cuando se incorporan emociones y deseos, el sujeto aprende para la vida. Este estudio revela que los niveles de deseo en los niños y niñas se han amplificado y que se requiere de un repertorio robusto de alternativas para trabajar pedagógicamente en esta frontera.

No se trata de convertir al maestro en vendedor, pero sí es claro, al decir de Piscitelli (2009), que es necesario reinventar la profesión sin detrimento de concepciones pedagógicas que continúan estando vigentes. Esta reinvención consiste en fungir como mediador, pero también provocar desestabilizaciones para fomentar puntos de vista, delimitación de problemas y formulación de alternativas. Más allá de los esquemas intelectuales que han invadido las didácticas de las disciplinas, el profesor-comunicador debe otorgarle mayor valoración a la complejidad, la perplejidad y el caos del mundo contemporáneo como contextos problematizadores que posibilitan nuevas formas de comprensión y acción.

Si la publicidad y el consumo son la industria (mundo) del deseo, la educación debería tramitar el deseo a favor del aprendizaje, la convivencia y la participación. La pedagogía debería convertirse en comunicación persuasivo-seductora a favor de la reflexión, la praxis y la liberación. Por esta razón, una de las claves para educar en la frontera del deseo está en la comunicación y en el reconocimiento de la emergencia de subjetividades hipermediales e interactivas, como efectos del tránsito de los niños y niñas por las transmediaciones en la CDI.

\section{PEDAGOGÍA DE LA PRESENCIA}

Los hallazgos relacionados con las nuevas formas de razonamiento de los niños y niñas (hipermediales e interactivas) y el panorama expuesto en torno a los tres principios de la educación convergente, corroboran que se ha posicionado progresivamente un nuevo régimen de lo sensorial, lo estético y lo cognitivo en las infancias. De entrada, esta afirmación sugiere la apa- 
rición inminente de un síntoma en la pedagogía moderna ${ }^{15}$ : la crisis de la representación del conocimiento en la escuela, como expresión de prácticas pedagógicas dedicadas preferiblemente a la administración de contenidos por la vía de la enseñanza de temas y el refuerzo de estos a través de actividades y evaluaciones.

La combinación de capacidades y oportunidades para ver, interactuar y producir en la CDI como una de las proyecciones más contundentes de la subjetividad de los niños y niñas en la Web, desborda la enseñanza basada en las representaciones de ciertos sistemas de conocimientos, los cuales han sido elegidos y, eventualmente, traducidos por el profesor. Mientras que los niños y niñas navegan, exploran e intercambian en contextos pantallizados e hiperconectados, los contenidos que enseña el profesor se basan en la exposición de códigos, la reproducción de procedimientos para resolver ejercicios, así como la verificación de informaciones mediante decodificaciones que se ponen en escena a través de pruebas y mediciones.

Este divorcio -objeto digno de análisis- no puede continuar profundizándose. De hecho, la base de estos mecanismos, ampliamente dominados por el profesor, se apoya en el modelo comunicativo emisor -mensaje-receptor-

\footnotetext{
${ }^{15}$ Sin ánimo de esquematizar, apoyados en Moacir Gadotti (20II), se puede considerar la siguiente clasificación de las pedagogías modernas: Pensamiento pedagógico moderno (la noción de didáctica en Comenio, las ideas innatas y la tabula rasa de Locke); Pensamiento pedagógico ilustrado (la presencia social del niño a través de Rousseau y el Emilio, el niño natural de Pestalozzi, la práctica de la reflexión metódica de Herbart, la noción de la educación pública-secular de la revolución francesa); Pensamiento pedagógico positivista (los conocimientos de mayor valor en Spencer, la sociología y la educación en Durkheim, la enseñanza mutua de Lancaster); Pensamiento pedagógico socialista (la crítica de la educación burguesa en Marx, la nueva escuela pública de Lenin, la pedagogía de la vida del trabajo en Makarenko, la escuela y la cultura en Gramsci); Pensamiento pedagógico de la Escuela Nueva (el pragmatismo en la educación de Dewey, métodos activos e individualización de la enseñanza en Montessori, la incómoda apuesta onto-genética de Piaget y la inauguración de una psico-pedagogía de la acción); Pensamiento pedagógico antiautoritario (la pedagogía por el trabajo y del buen sentido en Freinet, la educación centrada en el estudiante de Rogers, la autogestión pedagógica de Lobrot); Pensamiento pedagógico crítico (la reproducción social y la educación en Bourdieu y Passeron, la escuela dividida de Baudelot, la pedagogía de la resistencia de Giroux, Apple y MacLaren); Pensamiento pedagógico crítico en el currículo (el interés emancipador en la educación de Grundy, el currículo transformador en Stenhouse, la investigación-acción educativa de Elliott, la potencialidad del maestro en Kemis); Pensamiento pedagógico latinoamericano (la pedagogía del oprimido de Freire, la alfabetización popular de Rosa María Torres, la formación del profesor-pueblo de María Teresa Nidelcoff, el constructivismo de Emilia Ferreiro, la autonomía de la escuela de Tedesco).
} 
propio del broadcasting. Una de las características fundamentales de este viejo modelo es el predominio de la transmisión de información ${ }^{16}$. Particularmente, en el espacio escolar el transmisionismo ha sido uno de los caminos privilegiados por los profesores dada la prevalencia de planes de estudio cargados de extensos contenidos que, no solo deben ser enseñados completamente, sino evaluados. Además, el enfoque de competencias y estándares introducido en Colombia mediante la política educativa de los últimos diez años, el cual busca la máxima eficacia del contenido como mecanismo para optimizar desempeños, es improcedente y ahonda las distancias entre representación y experiencia.

Más allá de introducir oposiciones en torno a la categoría representación, la hipótesis que permite plantear la pedagogía de la presencia parte de distinguir el uso de la imagen en la educación como simulacro y ejemplificación para reemplazar un código o un sistema teórico (asumidos como verdaderos) frente a la experimentación convergente y transmediática de objetos virtuales (expresados en imágenes, sonidos, textos escritos, obras) como elementos constituyentes de acontecimientos, simulaciones y experiencias. Este tránsito de una pedagogía de la representación (basada en la administración del código por el profesor) a una pedagogía de la presencia, interpela tres categorías clave que han sido medulares en la pedagogía moderna: el currículo, las prácticas y la evaluación.

Las experiencias de transmediación y las formas de razonamiento hipermediales e interactivas de los niños y niñas que participaron de este estudio, muestran que la imagen no es un mero dispositivo que reemplaza lo real o un simulacro que ejemplifica un objeto. Esto indica que la imagen, comprendida tradicionalmente como la base primigenia de la representación, ya no puede ser asumida solamente como un recurso para objetivar el mundo «real». En el mundo de las hipermediaciones los niños y niñas interactúan entre ellos y con los contenidos, produciendo modificaciones y transustanciaciones que invocan la presencia, una forma de articular lo construido y lo simulado como virtual (Lévy, 2007; Rodríguez, 2008).

\footnotetext{
${ }^{16}$ Vale decir que este transmisionismo también puede ser empleado utilizando artefactos. El uso de TV, computadores y Video Beam no necesariamente implica hacer algo distinto a la administración del código, tal como se evidenció en la época de la Tecnología Educativa.
} 
$\mathrm{Al}$ respecto, es importante recordar a través de Pierre Lévy (2007, p. 33) que lo virtual comprende un conjunto de entidades desterritorializadas, capaces de generar en diferentes tiempos y espacios manifestaciones específicas, expresadas en la praxis de sujetos y grupos. Por esta razón, atendiendo a una lectura filosófica de lo virtual, se puede admitir que la potencia de algo que logra expresarse en una idea, una propuesta, una interpelación o una obra, puede producir efectos, acciones y variaciones en relación con un orden dado. Mientras que la representación es la construcción mental y social de algo que se introduce en el sistema de pensamiento humano, la presencia es virtualización, potencia y acción.

De otra parte, la presencia contiene otro atributo importante. En la intersección interactividad, hipertextualidad y digitalización se halla el germen de nuevas experiencias, las cuales traen consigo la reafirmación del presente y el ejercicio de una soberanía sobre el mundo mediante el cuerpo y sus diversas formas de ficcionalización ${ }^{17}$. Estos elementos operan como mediaciones para que el sujeto decida, apelando a identificaciones y prótesis sensorio-perceptuales que le permiten expresarse y fomentar iniciativas. Este aspecto es de mayor importancia, especialmente si se tiene en cuenta que la condición de la infancia ha sido conminada al aplazamiento de su presente y a su incorporación en una zona gris que combina felicidad idílica y anormalidad. Por esta razón, el acto sacrificial de su institucionalización es recompensado en el futuro, una vez el sujeto abandona la niñez y se vuelve adulto ${ }^{18}$.

Para Hans Gumbrecht (2005) existen tres particularidades fundamentales que definen el campo no hermenéutico de las culturas de la presencia. El primero tiene que ver con la autorreferencia humana, esto es, el tránsito de la mente como autorreferencia dominante (propio del cogito planteado por Descartes) al cuerpo como vector de la vida social y cultural. El segundo se centra en la relación entre el cuerpo y el mundo, cuya base estriba en el paso de una relación dicotómica entre el ser y el mundo a una relación en la que el ser (incluyendo su cuerpo) está en el mundo y lo habita mediante ficciones

${ }^{17}$ Como se apreció en el análisis de las subjetividades, tempranamente Nietzsche (1970) analizó este fenómeno a la luz de su denuncia a la falsa dicotomía entre hombre racional y hombre emocional. El lenguaje es el mediador de estas formas de ficcionalización que hace posible una suerte de sobrevivencia en medio de las convenciones sociales de la sociedad moderna.

${ }^{18}$ Estos aplazamientos traen como consecuencia la resistencia al presente de los niños por parte del mundo adulto, en la medida en que estos están en proceso de estructuración. 
que le permiten integrarse a las materialidades y experiencias para producir significados. El tercero se refiere a la relación entre el sujeto y el conocimiento, proceso que implica transitar de la administración del significado dado (mediante los sistemas de conocimiento hegemónicos) a la producción de un conocimiento revelado, es decir, a un nuevo alumbramiento, asociado con eventos de auto-des-ocultamiento del mundo ${ }^{19}$.

Aunque el planteamiento de Gumbrecht (2005) está dotado de notables argumentaciones de orden epistemológico y ontológico, que implicarían abordar los grandes debates de la filosofía moderna de los últimos cuatro siglos (racionalismo, empirismo, idealismo trascendental, hermenéutica, fenomenología, estructuralismo...), es importante resaltar por ahora cuatro ideas fundamentales de su propuesta que pueden ser útiles para considerar la arquitectura de la pedagogía de la presencia:

- En la historia de occidente se han configurado culturas hermenéuticas y culturas de la presencia.

- Las culturas de la presencia promueven la producción de sentido por la vía de la experiencia, el acontecimiento y la vivencia del presente.

- En las culturas de la presencia se tramita el sentido atendiendo a interacciones y vinculaciones entre cuerpos, sujetos y mundo.

- Las nuevas formas de comunicación pueden favorecer la cultura de la presencia y convertirse en un escenario para existir de otros modos, fomentando colaboración y proyectos colectivos.

De acuerdo con lo señalado, se puede afirmar que las producciones culturales (especialmente las transmediaciones) que tienen lugar en el tiempo presente, las expresiones (enunciados, textos, hipertextos, imágenes, obras) digitales e interactivas que circulan por el ecosistema comunicacional contemporáneo y las formas de agregación e identificación que los sujetos ejercen por la vía de los flujos y conexiones, promueven atmósferas de experiencia y pueden llegar a la construcción de inteligencias colectivas. Por esta razón, la pedagogía de la presencia plantea como premisa fundamental el fomento del

\footnotetext{
${ }^{19}$ Estas expresiones fueron brillantemente expuestas por Heidegger (1998) en Ser y Tiempo al mostrar las diferencias entre lo óntico y lo ontológico en torno a la figura del Dasein y el proceso que llamó acontecer.
} 
acontecimiento en la educación. Esto implica que el docente cambie el control de la representación y la regulación de los tiempos y espacios (expresado en las rutinas escolares) por experiencias que afecten la vida de los participantes.

Actualmente las experiencias fuera de la escuela son intensas, involucran pensamientos y acciones, exigen toma de decisiones y tienden a la conformación de redes y comunidades. Contar con ideas y condiciones para crear atmósferas de experiencia en la educación formal no es un asunto sencillo. Sin embargo, considerar el fomento de experiencias en la escuela, bajo estas consideraciones, contendría al menos dos componentes fundamentales para ser explorados: las simulaciones y la experiencia estética.

\section{LAS SIMULACIONES}

Las simulaciones se han convertido en los últimos años en uno de los objetos de estudio privilegiados por las investigaciones cTs y la ludología. Particularmente, Scolari (2010), en un texto esclarecedor al respecto, plantea que las simulaciones en la educación deben ser entendidas como extensiones cognitivas de los modelos mentales, las cuales no funcionan simplemente bajo los esquemas inductivos sino mediante interfaces gráficas que potencian la producción de mundos posibles. La simulación no es simulacro: implica la producción de presencia al incluir procesos como la comprensión de fenómenos, la recreación de alternativas, la interactividad y la capacidad del prosumidor para enfrentar eventuales incertidumbres.

Las simulaciones pantallizadas consisten en interfaces altamente interactivas que proveen estructuras, situaciones, recorridos, propiedades y elementos para que sus usuarios-prosumidores puedan resolver problemas y proyectar opciones. Los ejemplos son diversos: simulaciones en los negocios; para las guerras; como alternativa para proyectar el crecimiento de las ciudades $^{20} \ldots$ Generalmente, admite Schmucker (1999), las simulaciones deben operar en ambientes y experiencias complejas. El carácter experimental de estos ambientes puede resultar de gran utilidad para intervenir en problemas concretos, como los flujos de las bolsas de valores, el crecimiento de poblacio-

\footnotetext{
${ }^{20}$ Estos ejemplos son cuidadosamente analizados por Scolari (2010) a partir de un repaso por la historia de las simulaciones en sectores como la Defensa Nacional, el urbanismo y el espectáculo, así como en investigaciones asociadas con el campo de las neurociencias.
} 
nes y la intervención sobre variaciones y variables no consideradas al inicio de un proyecto.

No toda interactividad implica una simulación. Para Gonzalo Frasca (2003), la simulación es un proceso tan complejo que evidentemente desafía la representación como recurso de acercamiento a la realidad, al incorporar nuevas formas de aproximación del usuario a la imagen y a sus respectivos modos de intervención. Estos nuevos accesos a la imagen, convertida ahora en simulación, traen consecuencias muy importantes para la educación y la pedagogía: procesos cognitivos divergentes y abductivos; otros modos de leer textos (escritos y semióticos); desciframientos orientados por recomposiciones semióticas; resignificación del error al convertirlo en ruta posible de aprendizaje; capacidades para seleccionar y combinar datos y variables; pensar por la vía de las modelizaciones; un acento evidente en la toma de decisiones.

Apoyados en el recorrido efectuado por Scolari (2010), se pueden sugerir ocho grandes dimensiones de las simulaciones que vale la pena tener en cuenta para la estructuración de la pedagogía de la presencia. Estas son:

- Creación o recreación de un fenómeno: las simulaciones generalmente están basadas en ficciones que proceden de circunstancias históricas o inventadas y que plantean problemas y alternativas para su resolución.

- Comprensión de las situaciones que ocurren: a partir de la decodificación e interpretación de las situaciones presentes, el usuario-prosumidor se ubica en la interfaz y procede a explorar y aprender.

- Interactividad: consiste en la experimentación e intervención en las situaciones con sus variables y alternativas. Se produce una doble afectación: el usuario busca controlar la simulación y esta, a su vez, produce determinados efectos en sus emociones y acciones.

- Fundamento: la simulación está basada en un modelo o una perspectiva de la realidad que busca ponerse en escena mediante ficciones y mundos posibles.

- Impredecibilidad: en la simulación están presentes fenómenos aleatorios y una extrema sensibilidad de las acciones del usuario-prosumidor. 
- Toma de decisiones: el usuario-prosumidor debe valerse de valores y conceptos previos para enfrentarse a las situaciones, empleando tácticas y estrategias que le permitan resolver problemas.

- Realizar previsiones: el usuario-prosumidor es capaz de prever y delinear rutas y trayectorias para resolver los problemas presentes en las situaciones de la simulación.

- Diversión: son experimentaciones que contienen altos niveles emocionales, adscritos al placer y la satisfacción.

Las simulaciones están fuertemente emparentadas con los videojuegos. Como se pudo constatar en capítulos anteriores, los videojuegos contienen importantes potencialidades al situar narrativas que se valen de poderosos recursos semióticos para lograr la inmersión del jugador en un ambiente que lo deslocaliza y lo incorpora en ficciones, convirtiéndolo en protagonista. El videojuego online, particularmente, lo sumerge en la experimentación y la implementación de modelos dinámicos que pueden contener orientaciones compartidas y colaborativas. Por esta razón se trata de una mediación que amplía las fronteras de la experiencia y, por consiguiente, provee otras fuentes de conocimientos.

Finalmente, volviendo a Scolari (2010), se puede asegurar que las simulaciones en la educación son herramientas de conocimiento que contribuyen a la expansión del aprendizaje. Esta expansión no es enciclopédica sino más bien remodelizada, lo que implica una profunda alteración en los modos de leer, escribir, pensar y actuar. Los modelos experimentados y aprendidos le sirven al sujeto para aplicarlos en otras situaciones. Las tácticas y estrategias empleadas contribuyen a regular la toma de decisiones. La exploración de sistemas complejos contribuye a cualificar procesos como la abstracción y la generalización. Enfrentar la incertidumbre fomenta modos de previsión mediante proyecciones y correlaciones. La diversión atraviesa la experiencia de las simulaciones, por lo tanto favorece la convergencia emocional-reflexiva a la que se aludió anteriormente.

\section{LA EXPERIENCIA ESTÉTICA}

John Dewey (2011), una de las figuras más fascinantes de la educación y el pragmatismo de los inicios del siglo xx en occidente, hacia 1897 publicó una serie de escritos compilados en un documento titulado Adresses and proce- 
edings of the National Education Association ${ }^{21}$. Uno de sus ensayos, en el cual aborda los elementos estéticos de la educación, introduce una hipótesis que resulta extremadamente pertinente para ser incorporada en esta aproximación a las relaciones entre la pedagogía de la presencia y la experiencia estética.

Señalaba Dewey (2011) que la experiencia estética es un acto de libertad en el que los niños, mediante experiencias -más que sometidos a extenuantes rutinas- pueden desarrollar una serie de capacidades que les serán útiles para sus vidas. La primera capacidad tiene que ver con una suerte de reacción emocional a las ideas y los actos, proceso que favorecerá la formación de su carácter moral. La segunda está asociada con la posibilidad de reaccionar con cierta delicadeza y velocidad para enfrentar situaciones prácticas. La tercera implica una formación que equilibra el balance y el ritmo, de modo que el niño logre regularidad y cierta economía de las acciones. La cuarta capacidad se centra en la libertad de expresión, dado que la obra de arte es un medio que obliga a opinar, sensibilizarse y compartir emociones.

Finalmente, para Dewey la quinta capacidad que surge como potencialidad de la experiencia estética está relacionada con el placer. Particularmente, señalaba el pensador norteamericano en aquel tiempo, que la educación convencional había privilegiado el tratamiento intelectual en la adquisición de la información y que era preeminente el retorno de la noción griega de placer como un componente constitutivo de la educación.

Resulta sorprendente la vigencia de los planteamientos de Dewey (2011) frente a los desafíos de la pedagogía de la presencia y las condiciones socio-culturales y comunicativas del tiempo presente. Sin embargo, es aún más inquietante el llamado que hacía, a finales del siglo xix, a cambiar la educación dado el agotamiento del modelo racional-intelectual. Bajo estos presupuestos se puede afirmar que la experiencia estética es un proceso transversal a la educación que promueve criterios para la vida, que va más allá de la clase de educación artística y que no se supedita a la emulación de la producción artística en los niños y niñas.

${ }^{2 l}$ Se trata de un conjunto de escritos en los que Dewey (20II) aborda dos núcleos constitutivos de su obra: la estética y la educación, y la educación moral. 
El recorrido por las prácticas comunicativas de los niños y niñas en el mundo de las hipermediaciones sugiere que existe un ámbito de la experiencia estética tanto en los procesos de transmediación como en las nuevas formas de razonamiento y los capitales culturales que estos producen. Como se pudo apreciar, las experiencias hipermediales e interactivas de estos sujetos contienen percepciones, producciones y visiones colaborativas que pueden resultar potentes para introducir un ámbito de la experiencia estética en los fenómenos de la cDi como aporte a la pedagogía de la presencia.

La experiencia estética en la CDI es un fenómeno creciente que se identifica con perspectivas colaborativas y libres, las cuales suelen entrecruzarse con prácticas sociales y políticas. Al respecto es importante recordar a Lévy (2007), quien al introducir la noción de arte digital, declara que en los inicios del siglo xxi se manifiestan otras formas de existencia del arte, el artista y la obra. En lugar de un artista dotado de habilidades excepcionales para crear y exhibir la obra, en la cibercultura emergen ingenieros de mundo, quienes se encargan de coordinar equipamientos colectivos para intervenir de diversas maneras en obras interactivas.

Este suceso presenta aportes significativos para la construcción de la pedagogía de la presencia. La obra digital no es estática y, evidentemente, ya no funge como objeto de exposición en un espacio prototípico de la modernidad, como es el museo $^{22}$. En la cDI, la obra es un entorno inacabado que involucra a proponentes, exploradores y participantes, quienes, a partir de diversos grados de experimentación con la obra, pueden producir sentidos múltiples, variables e inesperados. Esto tiene una consecuencia crucial en la vida de las personas: nuevas sensibilidades y nuevas fuentes para fomentar la creación.

Los entornos de la CDI que exploran los niños y niñas permiten algunas aproximaciones a estas nuevas condiciones estéticas analizadas por Lévy (2007). Por ejemplo, la incorporación de iniciativas para intervenir imágenes y fotografías exige en ellos y ellas capacidades de percepción, interacción y producción en relación con la pieza digital puesta en escena. El uso de aplica-

\footnotetext{
${ }^{22}$ En la modernidad el museo está basado en la exaltación del artista y de la obra, aunque también ha fungido como un escenario para la conservación y la exhibición del patrimonio. No obstante, vale destacar el esfuerzo que recientemente han adelantado los museos de muchas ciudades del mundo consistente en la virtualización de sus colecciones y exposiciones. Los usuarios pueden hacer recorridos online e interactuar de manera simple con la obra. En Colombia han emprendido esta importante tarea los museos Nacional y del Oro.
} 
ciones y de programas - como el conocido PhotoShop ${ }^{23}$ - para alterar contenidos de fotografías, así como ciertas habilidades emergentes que aplican para combinar imágenes 2D y tridimensionales, textos escritos y fotografías, entre otros, son prácticas habituales en las que lo estético se convierte progresivamente en una dimensión constitutiva de sus propias tramas narrativas. Por supuesto que estas prácticas acentúan formas de ser y estar en el mundo ${ }^{24}$.

De otra parte, aunque ninguno de estos sujetos hace mezclas o compone música, es importante resaltar cómo algunas experiencias de transmediación a través de la música hacen posible la constitución de paisajes sonoros que acompañan su existencia. Estos paisajes suelen conformarse a partir de archivos de audio, videos y textos escritos, que se ordenan y complementan alrededor de un artista o un género. Para estos niños y niñas la producción de presencia a través de la música es fundamental, pues no solo se conforman con escuchar el audio de una canción. La canción se experimenta de diversas maneras: se escucha, se aprende su letra (así esté en otro idioma), se recrea en el video y hasta se puede interpretar en diversos instrumentos.

Finalmente, también producen videos para compartir a través de recursos básicos (cámaras del teléfono móvil, cámaras fotográficas y de video sencillas) y utilizando programas simples como Movie $\mathrm{Maker}^{25}$. Aunque los contenidos de los videos son básicos, esta tendencia permite afirmar que la producción de videos estimula la percepción sobre los fenómenos del mundo de la vida y hace posible observar de modo distinto la realidad. La inauguración de estas nuevas formas de percepción y de interpretación es importante. Sin embargo, lo más destacable es la incorporación de estas pequeñas obras en la Web mediante enlaces y formas de interacción diversas (por ejemplo usando podcast

${ }^{23}$ El PhotoShop es un programa dinámico que emula un taller de pintura y fotografía, el cual trabaja sobre un lienzo virtual. Está orientado principalmente a la edición, retoque fotográfico y pintura de obras a partir de imágenes del mapa de bits. Aunque cuenta con varias versiones, el más conocido es Adobe PhotoShop. Disponible en http://www.adobe. com/es/products/photoshop/photoshop/languages/. Consulta realizada el 20 de febrero de 2012.

${ }^{24}$ Existen miles de aplicaciones que abren opciones de creación y autogestión en múltiples formas de expresión y lenguajes hipermediales.

${ }^{25}$ Es uno de los programas ampliamente utilizados por los niños y niñas. Técnicamente es un software de edición de video, de amplia versatilidad, creado por Microsoft. La aplicación permite a los usuarios producir efectos, títulos o créditos, realizar transiciones, hacer narración cronológica e insertar pistas de audio. 
y hatchtack), los cuales potencian semiótica y socialmente su exploración, uso $\mathrm{y}$ apropiación por parte de otros ${ }^{26}$.

Estos elementos hacen necesario acudir a otro referente que resulta iluminador para comprender la mutación cultural, expresada en la estética contemporánea. Se trata de los trabajos de Nicolás Bourriad (2004), quien ha explorado durante varios años este problema a través de dos categorías analíticas: la estética relacional y la postproducción. Mientras que la primera es una aproximación a lo que el autor denomina aspecto convivial e interactivo de la revolución tecnológica (cuya consecuencia es la tendencia de los artistas a producir nuevos modelos de sociabilidad), la postproducción se centra en las formas de saber generadas por la aparición de la red. En términos de Bourriad, implica entender cómo orientarse en el caos cultural de la Web y deducir de ello nuevos modos de producción.

Para Bourriad (2004), la noción de originalidad evidentemente ha entrado en una etapa de difuminación, dado el advenimiento del paisaje cultural contemporáneo. Algunas de las figuras que mejor expresan el desenvolvimiento de esta mutación en el ámbito de lo estético son el DJ y el programador. Estos tienen en común dos actividades fundamentales en la producción cultural del tiempo presente: seleccionar objetos culturales e insertarlos dentro de contextos definidos.

El prefijo post no alude a ninguna negación ni superación. Designa una zona de actividades y una nueva actitud que conjuga uso (consumo) y apropiación (producción). La lógica de la postproducción no se supedita únicamente a producir imágenes de imágenes, sino que busca inventar protocolos de uso divergentes para los modos de representación y las estructuras formales existentes. Bourriad (2004) insiste en comprender la postproducción como experiencias que buscan apoderarse de todos los códigos de la cultura, de todas las formalizaciones de la vida cotidiana, de todas las obras del patri-

\footnotetext{
${ }^{26}$ En el análisis de las prácticas comunicativas fue posible observar lo que hace Camilo al enlazar su perfil de Facebook con Twitter, YouTube y su blog personal. Es frecuente su implicación en las conversaciones y en las obras mediante podcasts (suscripción a un sitio hablado que incluye noticias, documentales, música, debates, entrevistas) y hachtacks (tema en el que cualquier usuario puede hacer un aporte o dar opiniones respecto a un tema abierto escribiendo a través de una cadena de caracteres tras la almohadilla que anuncia el tema).
} 
monio mundial, y volverlos a crear. Aprender a servirse de estas formas de representación supone apropiarlas y habitarlas.

Las actividades del DJ, del WebSurfer y del artista de postproducción se centran preferiblemente en la invención de itinerarios a través de la cultura. Los tres son semionautas, al decir de Bourriad (2004), esto es, sujetos comprometidos en producir recorridos originales entre los signos. Esto significa que toda obra es el resultado de un escenario proyectado sobre la cultura, asumida como el marco de una serie de relatos que, a su vez, posibilitan nuevos escenarios de exploración y producción en un movimiento infinito de imaginación y creación ${ }^{27}$. Sus principales procesos de producción son el remix, el mash-up, el montaje de piezas, la combinación de fuentes sonoras y visuales, el efecto especial, la traducción, la hipérbole sonora y el subtitulado.

Más allá de lo novedosas que puedan resultar estas actividades, lo más importante es que estos acontecimientos evidencian cómo las creencias y actitudes frente a lo original e inalterable (nociones representativas del logocentrismo y el enciclopedismo de la modernidad) están empezando a cambiar en la práctica. Por ejemplo, el músico que utiliza el sampler sabe que, en un momento dado, su composición podrá ser retomada y servir como insumo para una nueva composición. Los fragmentos sonoros surgidos del sampling hacen parte tan solo de un punto de expresión que sobresale en una cartografía móvil, la cual se expande infinitamente a través de las redes digitales ${ }^{28}$.

Finalmente, se trata de un proceso inmerso en una cadena de significación cuyos sentidos dependen de la posición que los partícipes ocupan en ella. La

\footnotetext{
${ }^{27}$ Afirma Bourriad (2004): «El DJ activa la historia de la música copiando/pegando trozos sonoros, poniendo en relación productos grabados (...) El sampler, máquina de reformulación de productos musicales, implica también una actividad permanente; escuchar discos se vuelve un trabajo en sí mismo, que atenúa la frontera entre recepción y práctica, produciendo así nuevas cartografías del saber. Ese reciclaje de sonidos, imágenes o formas implica una navegación incesante por los meandros de la historia de la cultura-navegación que termina volviéndose el tema mismo de la práctica artística».

${ }^{28} \mathrm{Al}$ respecto es importante destacar los principios del Manifiesto Remix: «La cultura se construye a partir del pasado; el pasado siempre intenta controlar el futuro; nuestro futuro está perdiendo su libertad; para construir sociedades libres debemos limitar el control del pasado». Rip es un manifiesto que está seriamente comprometido en la lucha contra la propiedad intelectual, un modelo que ya no solo es problema de los artistas y las compañías, sino de los prosumidores. El film de Brett Gaylor (2008) ha sido uno de los principales medios de difusión de esta perspectiva política y estética. Disponible en http:// ripremix.com/. Consulta realizada el 15 de febrero de 2012.
} 
actividad de las redes sociales en Internet y los foros, por ejemplo, adquiere valor para el prosumer en el momento en que es retomado y comentado por alguien más. De este modo, la obra de arte contemporáneo no puede ser entendida simplemente como la conclusión del proceso creativo, según Bourriad. No se trata de un producto finito para contemplar. Es ante todo un espacio-tiempo de orientación, un contexto que potencia experiencia y presencia.

Tal vez, lo más importante de este acontecimiento es la emergencia progresiva de una especie de inclusión en, con y a través de la experiencia estética. Esto supone que entre el yo (que está situado en los surcos de un dispositivo o de una interfaz) y el otro (quien usa y apropia, según de Certeau), se pueden establecer capacidades compartidas y expandir redes de relaciones (Bajtin, 1997). Esto no implica renunciar a las diferencias y puntos de vista de los involucrados, quienes potencian la acción social y su propia historicidad.

Volviendo a la necesidad de incluir la experiencia estética como uno de los componentes estructurales de la pedagogía de la presencia, vale retomar la hipótesis de Dewey (2011) enunciada al inicio de este apartado. La experiencia estética, como experiencia de libertad, fomenta capacidades que, sobre la base de otros modos de percepción del mundo y de la vida, favorecen la praxis moral, social y política, así como cierta propensión a compartir atendiendo a dimensiones emocionales y reflexivas. Esto significa que la experiencia estética es una postura socio-moral, una actitud y un sistema de atributos que el sujeto pone en escena mediante la acción con el otro. La experiencia estética, como dimensión trasversal de la pedagogía, debe fomentar la percepción estética, la producción estética y el dominio crítico en el contexto de la cultura (Eisner, 1995) ${ }^{29}$.

En relación con la percepción, el planteamiento de Eisner (1995) es simple pero de gran relevancia para la pedagogía de la presencia: los niños y niñas

\footnotetext{
${ }^{29}$ Eisner es uno de los autores más importantes en los debates recientes sobre la educación artística y la estética en los niños y niñas. Algunas de estas ideas son tomadas de un texto titulado Educar la visión artística (1995). En este trabajo Eisner describe las formas de pensamiento que las artes potencian. Las describe como necesarias para la vida dado que permiten abordar las ambigüedades y las incertidumbres de la vida cotidiana, que generalmente los currículos formales no aplican en la escuela. Según Eisner, este nuevo punto de vista es útil, especialmente en un momento de la historia en el que la educación está dominada por formas mecanicistas, propias del racionalismo técnico.
} 
deben ser capaces de percibir relaciones más que códigos o representaciones, proceso que no se supedita a las capacidades que proveen las operaciones mentales subyacentes a su madurez evolutiva, sino que depende especialmente del tipo de experiencias que éstos vivan en su cotidianidad. Estas experiencias no solo ocurren en los contextos escolares, sino especialmente en los extra-escolares. Como se ha apreciado, buena parte de los contextos de percepción y de acción que prefiguran la vida de los niños y niñas en la cDI, se destacan por su hipermedialidad e interactividad, asunto que evidentemente amplifica las formas y los registros de la percepción.

Eisner (1995) analiza algunas limitaciones que inhiben las posibilidades de expansión de la percepción en personas que viven en ambientes poco estimulados. En primer lugar, observa la presencia de constancias visuales, las cuales se vuelven casi necesarias para muchas personas en su vida cotidiana, pero que les impiden el reconocimiento de las discontinuidades de los sistemas de significado. En segundo lugar, evidencia la existencia de estructuras de referencia en la mirada de las personas, comprendidas como moldes que tienden a acentuar generalidades de los sistemas representacionales, obstaculizando así la lectura de sus particularidades. Finalmente identifica la centralización, entendida como una suerte de focalización del mundo visual, que restringe la potenciación de la comprensión relacional y compleja de los sistemas subyacentes a lo visual-sonoro.

Sobre la dimensión de la producción, Eisner (1995) propone un dominio productivo de lo estético que abarca varias habilidades: habilidad en el tratamiento del material; habilidad para percibir cualidades emergentes en el material con el que se está trabajando, en el entorno y en las imágenes mentales; habilidad para inventar formas que satisfagan a quien las produce; y habilidad para la creación de un orden espacial que favorezca la expresión. En relación con el dominio crítico-cultural, Eisner expone tres grandes procesos en la relación sujeto-obra como el carácter simbólico de la obra (formas divergentes de decodificación como producción de sentido), el factor afectivo-temático de la obra (reflexión sobre las emociones y sentimientos involucrados al enfrentarla) y la condición contextual de la obra (reconocimiento del devenir y de los planos temporo-espaciales que la configuran).

Aunque Eisner (1995) no ingresa en la reflexión sobre el arte digital o la postproducción, es importante destacar sus aportes pedagógicos en torno a la 
estética y la educación, más allá de los elementos convencionales que asocian estos procesos con la clase de educación artística en la escuela. Al igual que Dewey (2011), este intelectual norteamericano destaca la experiencia como un proceso que afecta y produce las condiciones necesarias para que los sujetos puedan percibir, pensar y actuar de manera relacional y contextual. Particularmente la experiencia estética, en el contexto de la pedagogía de la presencia, la cual encuentra su modo de expansión a través de la CDI, implica implementar estos tres procesos (percepción, dominio productivo y dimensión crítico-cultural) por diversas vías.

En relación con la percepción, es fundamental fomentar prácticas pedagógicas cuyos escenarios sean las interfaces gráficas de la Web 2.0, los videojuegos, las simulaciones y los mundos virtuales. $\mathrm{Al}$ respecto, las recomendaciones de Eisner (1995) -recontextualizadas a la CDI- son centrales: ir más allá de la focalización; superar las estructuras de referencia que anclan la mirada en un aspecto episódico del objeto virtual; e identificar enlaces y nodos que permiten comprender los indicios, las trayectorias y las configuraciones virtuales del objeto digital.

Alrededor de la producción, es importante destacar que los elementos digitales e interactivos en la cDI permiten intervenir aquello que Eisner denomina materiales. De este modo, es necesario favorecer prácticas pedagógicas que sitúen a los niños y niñas en ambientes virtuales y que les permitan experimentar con los objetos allí presentes. Esta experimentación, siguiendo a Eisner (1995), consiste en el reconocimiento de los atributos de estos objetos, su alteración figurativa, su recreación en otros contextos y su descentramiento para ser situados en otros espacios virtuales. Aunque este nivel exige de estudiantes y docentes con amplias habilidades para navegar y experimentar en la CDI, las formas de razonamiento hipermediales e interactivas halladas en los niños y niñas hacen viable la potenciación de este tipo de prácticas pedagógicas.

Finalmente, la lectura crítico-cultural a la que alude Eisner es fundamental en la pedagogía de la presencia y en la experiencia estética. Para tal efecto, es necesario construir conjuntamente capacidades para que el sujeto enfrente la obra y establezca marcos de comprensión en torno a sus propias emociones y a las fuentes sociales, políticas y culturales que la constituyen. De este modo, el profesor debe fomentar experiencias estéticas que amplíen 
los grados de libertad y de sensibilización frente a obras que, evidentemente, están profundamente mediadas por dispositivos e interfaces. En esta etapa los docentes deben crear las condiciones para que los niños construyan estructuras de referencia flexibles y abiertas, que descentran los objetos, sus significados y sus relaciones.

\section{MEDIACIONES PEDAGÓGICAS Y POTENCIACIÓN DE SUJETOS}

Sin que hayan sido enunciadas de esta manera en sentido estricto, las mediaciones pedagógicas tienen una larga trayectoria en la historia de la educación y la pedagogía. Si se parte del concepto de paideia de los griegos, se puede afirmar que la palabra, el ritual del encuentro y la incursión en saberes asociados con la verdad, la justicia y la belleza (trilogía central en la educación planteada de distintos modos por Platón y Aristóteles), contenían una serie de implicaciones pedagógicas profundas que se surtían en la propia práctica.

La congregación de ciertos sujetos alrededor de la reflexión y de las preguntas, le permitía a los maestros y aprendices penetrar en una órbita de sentido, capaz de dotarles de herramientas para enfrentar las complejas preguntas de su época: ¿Relación Dios-seres humanos?, ¿Gobierno y democracia?, ¿Conocimiento y cultura?, ¿Estética y existencia? Los medios para aprehender lo nuevo, así como una inquietud constante por utilizar argumentos legítimos en la labor de persuadir a los auditorios en torno a temas trascendentales para la vida ${ }^{30}$, pronto empezaron a aparecer como una preocupación vital para los maestros y mentores de la época.

Más adelante, la historia de Abelardo muestra que la conquista de un espacio social que rompiera con la imagen convencional del aula de clase, se hizo plausible en una nueva práctica pedagógica que, a su vez, se volvió práctica política como medio para subvertir el orden social. Hacia el siglo $\mathrm{xI}$, el ingenio de este hombre a través de la diatriba dialéctica y un dominio silogístico profundo, le permitió convocar aprendices jóvenes a un ejercicio heurístico permanente, que trascendió la institucionalidad universitaria

\footnotetext{
${ }^{30}$ La persuasión tiene que ver con la argumentación. Inicialmente Aristóteles lo plantea en su Retórica y luego Perelman inicia todo un campo de discusión al respecto a través de su trabajo titulado Tratado de la Argumentación. La Nueva Retórica (1989).
} 
dado que el escenario en el que podía desplegar con gran elocuencia la interacción era el mundo natural, así como propuestas de giros inesperados para problematizar la época ${ }^{31}$.

Posteriormente, en medio de grandes debates entre idealistas, racionalistas, empiristas, naturalistas y otros, que probablemente estaban más cercanos al futuro historicismo como núcleo del pensamiento, las formas de enseñanza apelaron a dimensiones técnicas y didácticas para lograr sus objetivos, tal como lo mostraron Comenius, Herbart y Rousseau. Sin embargo, en una perspectiva distinta, uno de los más conocidos fue el modelo de enseñanza mutua de Lancaster, el cual se basaba en la inclusión de un alumno monitor (niño avanzado), quien mantenía comunicación directa con el maestro y, a su vez, daba instrucciones a los demás alumnos ${ }^{32}$.

Aunque el ejemplo de Lancaster puede resultar contradictorio para lo que significa el valor de la mediación, es claro que las disposiciones y condiciones del aula pueden apuntar a intereses distintos. En este caso, es claro que los medios y las condiciones de trabajo en el aula presentadas por este pensador del siglo XIX, estuvieron orientadas hacia una economía del lenguaje y de las propias prácticas con propósitos de eficiencia, en concordancia con las lógicas del orden social predominante, al servicio del naciente capitalismo y sus correlatos centrados en la civilización y el progreso.

Sin embargo, así como el uso de dispositivos diseñados con fines autoritarios pueden llegar a ser efectivos en la tarea de evitar problemas propios de la práctica pedagógica del profesor, es importante registrar en este discreto inventario otras maneras de asumir los componentes comunicacionales e instrumentales de una vinculación pedagógica diferente. Lev S. Vygotski (1996) planteó que en la educación de una persona, era necesario identificar una zona de desarrollo que partiera de lo real y se proyectara hacia lo potencial.

${ }^{31}$ Obviamente las instituciones medievales y los sistemas de producción de conocimiento imperantes lo señalaron, a propósito de sus críticas e irrebatibles respuestas a un diálogo permanente en el que la autonomía intelectual estaba en el centro de su praxis.

${ }^{32}$ Este mecanismo demuestra la funcionalidad en la incorporación de los niños en una tecnología escolar de corte piramidal que, además de clasificarlo, lo disponía en cuerpo y alma a la regulación y autorregulación del tiempo y el espacio, le daba un lugar en la ritualización institucional y demarcaba explícitamente la diferencia del que sabe y el que no sabe. 
Esta imagen, ampliamente evocada en la educación y la pedagogía, resultó innovadora en su momento dados sus matices socio-históricos.

Para el pensador ruso, conocer al sujeto y su tránsito por esta zona, la cual evidentemente asume al sujeto historizado y situado en la sociedad y la cultura, debe ser la base de la experiencia. En tal sentido, medios, mediaciones y en general las condiciones necesarias para construir la experiencia, se constituyen en los principales componentes que hacen posible la potenciación del sujeto hacia el desarrollo, el cual, en su perspectiva, no siempre está ligado a etapas y secuencias.

De otra parte, Paulo Freire (2005), bajo una percepción histórico-cultural y política propia de una región subordinada a la dominación y la exclusión, propuso una forma de educación que trascendiera los escenarios escolares e institucionales como criterio para superar la educación bancaria, a través de una práctica que observa en lo popular una oportunidad para la construcción de alternativas al orden hegemónico. No se trata de una mera alfabetización de los pobres sino de una práctica de libertad.

En Freire el lenguaje es el medio más importante para iniciar la praxis liberadora, la cual empieza por el propio profesor, quien debe proyectar desde su propia vida las formas posibles de superar la opresión. El tránsito de una pedagogía del oprimido que permita develar las formas de dominación, hacia una pedagogía de los hombres en permanente proceso de liberación, es el programa de la educación popular y la piedra angular de la pedagogía crítica en sus diversas acepciones ${ }^{33}$.

¿Qué tienen en común estas experiencias y concepciones sobre la educación, la pedagogía, la enseñanza, el sujeto y la sociedad? Aunque la constelación de perspectivas agrupadas resulte un riesgo dada su diversidad, un elemento central en todas estas discusiones tiene que ver con las condiciones

\footnotetext{
${ }^{33}$ Sin el ánimo de esquematizar los importantes esfuerzos al respecto, se puede señalar que la pedagogía crítica tiene cuatro focos de trabajo centrales en el mundo: la escuela de Freire en América Latina, actualmente liderada por Moacir Gadotti, director del Instituto Freire en Sao Paulo; el grupo liderado por Stenhouse y Elliot de la escuela británica, en diálogo con Kemmis y Car; el grupo que orienta Shirly Grundy en Australia; y el grupo que conforman Apple, Giroux y McLaren, especialmente conocidos en EeUu y América Latina.
} 
socio-culturales que, basadas en intencionalidades específicas, permiten llevar a cabo un proyecto, un programa y/o una apuesta política específicos. $\mathrm{Si}$ en la paideia griega los instrumentos de conocimiento son desplegados mediante la retórica y el poder de la palabra en la persuasión del otro, en Vygotski y Freire es la praxis historizada y orientada como potenciación, la que permitirá llevar a cabo conquistas de diverso orden en la sociedad, tanto conducidas por el desarrollo del sujeto como por la búsqueda de su liberación.

De este modo, si la pedagogía es considerada un campo cuyo núcleo es el saber y la praxis pedagógica, los cuales, evidentemente trascienden los sistemas de conocimiento disciplinar adquiridos y reproducidos por el profesor, entonces es necesario indagar y reflexionar sobre las condiciones que pueden hacer posible la emergencia de dominios de conocimiento que cobren sentido para la vida de los sujetos del aprendizaje. Se trata de condiciones socio-culturales, políticas, éticas y estéticas que, situadas en tiempos y espacios concretos, contribuyan a la potenciación de estos sujetos (Zemelman, 2007).

La mediación pedagógica, como base fundamental de la praxis y del saber pedagógico, implica establecer relaciones complejas y no siempre secuenciales entre el presente y el futuro. Esto significa que la identificación de las condiciones reales de un sujeto y/o de un colectivo deben ser punto de partida para abordar, al menos, dos elementos primordiales de su cualificación moral, estética, científica y socio-política: la posibilidad y la potencia. Mientras que la primera refiere a las condiciones de existencia actuales (no solo entendida como debilidad sino como opción de futuro), la segunda implica proyectar los caminos y las metas para la liberación.

La mediación pedagógica es una condición necesaria para producir praxis, experiencias y acontecimientos en la educación. No se trata de dispositivos técnicos planteados como ayudas educativas o instrumentos para llevar a cabo la enseñanza conforme a los sistemas canónicos de conocimiento. En términos de lo expuesto hasta el momento, la mediación pedagógica es la construcción de un escenario colectivo de alternativas, en el que la interacción del binomio potencialidades (lectura de las posibilidades desde el presente) y construcción de mundos posibles (identificación de metas y condiciones de existencia en la vía del desarrollo y la liberación hacia el futuro), halla en el tiempo y el espacio de la pedagogía sus formas de concreción. 
Basados en esta aproximación a la noción de mediación pedagógica ${ }^{34}$ y apoyados en los elementos expuestos anteriormente (educación convergente y pedagogía de la presencia), se pueden destacar como elementos estructurales de la mediación, los siguientes:

- Condiciones espaciales y temporales (ambientes de aprendizaje) para fomentar experiencias pedagógicas (acontecimientos).

- Medios que articulen lo textual, lo visual y lo sonoro para favorecer aprendizajes colectivos.

- Instrumentos de conocimiento que permitan a los sujetos del aprendizaje organizar la información y hacerla inteligible, empleando procesos como la abducción y las convergencias.

- Mecanismos para que los sujetos del aprendizaje puedan intervenir contenidos procedentes de distintos sistemas de conocimientos y producir nuevas formas de expresión del fenómeno, objeto de estudio o problema de conocimiento.

- Mecanismos para que los sujetos del aprendizaje puedan comunicar lo aprendido y producido. El escenario de comunicación debe ser abierto y expansible, de modo que otros puedan intervenir en la producción y continuar su elaboración.

\section{(HIPER) MEDIACIONES PEDAGÓGICAS E INTELIGENCIA COLECTIVA}

Para finalizar este recorrido, se propone la categoría (hiper) mediaciones pedagógicas, comprendida como un intento por actualizar los elementos de la

\footnotetext{
${ }^{34}$ Es obligatorio aludir a dos referentes que han empleado de distintos modos el término mediación. En primer lugar, el profesor Martín-Barbero (2003) plantea que las mediaciones están íntimamente relacionadas con los procesos sociales, las prácticas, los lenguajes y la pluralidad de matrices culturales en las que el sujeto es su nicho de mutación constante. Por su parte, Beatriz Finholc (1999) considera que la mediación pedagógica es una perspectiva que debe superar la lógica instrumental de la comunicación y la tecnología en la educación, especialmente si se la asume como una posibilidad para construir ambientes (presenciales y/o virtuales) que contribuyan a la generación fecunda y legítima de diversas formas de interactividad, atributo fundamental de la pedagogía.
} 
mediación presentados anteriormente, ahora en el contexto de la CDI. También es presentada con el fin de avanzar en los elementos clave de una propuesta pedagógica que explicite con mayor contundencia, a partir de los criterios desarrollados en la educación convergente y la pedagogía de la presencia, la relación entre las subjetividades emergentes de las infancias contemporáneas y la implementación de nuevas prácticas pedagógicas en la escuela.

Para tal efecto, es conveniente recordar que los niños y niñas nacidos desde la década del noventa en adelante (como aquellos que participaron en calidad de testimoniantes en este estudio) ingresaron desde su nacimiento, bajo distintos matices e intensidades, en una nueva órbita de la subjetividad. Se trata de una nueva forma de ser sujetos que se cristaliza en su travesía por diversos entornos y culturas. Uno de los entornos que ha operado como repertorio especial de estos procesos de subjetivación es la cDI. Este contexto fue abordado de dos maneras: como mutación socio-cultural, acontecimiento enmarcado en la conformación de un nuevo programa cultural (cultura audiovisual y transmediaciones); y como mutación comunicacional, acontecimiento en el que se constató la emergencia de formas de razonamiento hipermediales e interactivas así como nuevos capitales culturales en los niños y niñas.

Basados en estos elementos, fue propuesta la educación convergente y la pedagogía de la presencia. Mientras que la primera promueve una nueva educación a partir de convergencias entre distintos sistemas y referentes de aprendizaje (cultura popular, digital y escolar; aprendizajes invisibles y conocimientos formales; educación en la frontera emocional), la segunda profundiza en una pedagogía que se apoya en experiencias y procesos asociados con la cDI y la cibercultura, esto es, las simulaciones y la experiencia estética como aportes centrales para la nueva educación.

Aunque Scolari (2008) no busca situar la categoría hipermediaciones en el campo de la pedagogía, este recorrido sugiere que a partir de éstas se pueden potencializar nuevos ambientes de aprendizaje y otras prácticas pedagógicas en la escuela. Las hipermediaciones constituyen en la práctica zonas de hibridaciones por las que transitan lenguajes, contenidos, interacciones, medios, socialidades y sensibilidades. Estas zonas, pese a los riesgos que contienen dada la presencia explícita de los intereses del mercado del entretenimiento y la circulación de poderes hegemónicos a través de éstas, también potencian inteligencias colectivas y procesos de creación. 
Las experiencias comunicativas (generalmente mediadas por pantallas e hiperconexiones) propician nuevos repertorios culturales que orientan el devenir de los niños y niñas y sus modos de transitar por los sistemas de paso que los convierten en mutantes (Baricco, 2007). Como se apreció, estos sistemas de paso comprenden recorridos hipermediales e interactivos, no solo a través de la apropiación de aplicaciones de las redes sociales sino mediante los procesos relacionales conquistados por medio de los enlaces que producen, por la vía de canales de video, videojuegos, hipermediaciones y mundos virtuales.

Además de una alta dosis de potencia, expresada en la proyección de mundos posibles y la producción de nuevos capitales culturales, las hipermediaciones, implementadas con intencionalidades pedagógicas, pueden favorecer en la práctica el logro de los propósitos de la educación convergente y la pedagogía de la presencia. Esta hipótesis parte de reconocer el papel que la CDI juega en torno al advenimiento del nuevo perfil de niños y niñas que en la actualidad habitan la escuela: tienen nuevas formas de comprender el mundo; acceden a recursos que permiten problematizarlo de otras maneras; acceden a mecanismos que pueden fomentar el trabajo colaborativo; y apelan a diversos canales que están a disposición para favorecer la inteligencia colectiva.

En suma, las hipermediaciones pedagógicas pueden ser comprendidas (al igual que las mediaciones) como la construcción de escenarios colectivos de alternativas para la formación moral, científica, socio-política y estética mediante la complementariedad de potencialidades (lectura de las posibilidades desde el presente) y la construcción de mundos posibles (identificación de metas y condiciones de existencia en la vía de la potenciación y la liberación hacia el futuro). Sin embargo, las hipermediaciones pedagógicas plantean dos elementos adicionales sin renunciar a la potenciación y la liberación. Estos son la inteligencia colectiva en la educación y la presencia de otros elementos estructurales que permiten su funcionamiento.

\section{INTELIGENCIA COLECTIVA EN EDUCACIÓN}

En la respuesta a la pregunta de Pierre Lévy (2004) ¿Qué es la inteligencia colectiva? se destacan tres elementos clave que sirven como punto de partida para el desarrollo de esta propuesta. En primer lugar, se trata de una inte- 
ligencia repartida en todas partes, valorizada constantemente, coordinada en tiempo real y conducente a movilizaciones efectivas. En segundo lugar, su objetivo principal es el reconocimiento y enriquecimiento mutuo de las personas (no el culto de comunidades fetichizadas). Y en tercer lugar, también puede ser entendida como un conjunto de energías y experiencias humanas desafortunadamente desperdiciadas que, teniendo el potencial para la movilización, infortunadamente suelen despreciarse.

Agrega Lévy (2004) que los nuevos sistemas de comunicación deberían ofrecer a los miembros de las comunidades los medios necesarios para coordinar sus interacciones en el mismo universo virtual de conocimientos. No se trataría solamente de fomentar mecanismos para concebir el mundo físico ordinario, sino también de permitir a los miembros de colectivos específicos interactuar dentro de un paisaje móvil de significaciones. A esto habría que agregar que si Lévy observa en las formas de comunicación contemporáneas dificultades para llevar a cabo estos propósitos, el panorama en las instituciones es mucho menos halagüeño.

De otra parte, si las nuevas formas de comunicación así lo permitieran -continúa Lévy-, los acontecimientos, las decisiones, las acciones y las personas estarían situados en mapas dinámicos de contextos compartidos, transformando continuamente el universo virtual dentro del cual estos toman sentido. En esta perspectiva, el ciberespacio se convertiría en el espacio inestable de las interacciones entre conocimientos, sujetos del aprendizaje y colectivos inteligentes. El filósofo francés cierra su análisis afirmando que los conocimientos oficialmente validados solo representan hoy una pequeña parte de los que son activos, asunto que corrobora dos realidades: potencialidades y desprecios.

Basados en esta primera aproximación, se puede señalar que los modos de potenciación de sujetos en la cDI y en la cibercultura no ocurren bajo las lógicas de la enseñanza de asignaturas, el uso de textos escolares ni la ubicación de estos en espacios cerrados (por ejemplo el aula de clases). En segundo lugar, las lógicas de funcionamiento de la inteligencia colectiva lejos están de la reproducción, el sostenimiento del statu quo o la inmutabilidad del orden social. En tercer lugar, es evidente que el sistema institucional no reconoce la riqueza colectiva que contiene este tipo de inteligencia. 
La escuela, como parte del sistema institucional, es una de las primeras en desconocer este tipo de inteligencia e incluso promueve su desprestigio. Por esta razón, la inteligencia colectiva en la nueva educación es un propósito que debe ser adelantado con precauciones, pero con decisión. Hasta el momento, a pesar de un creciente esfuerzo de pedagogos, activistas, intelectuales y algunas instituciones, se reafirma el imaginario de educar no solo para sostener el statu quo y reproducir el orden social, sino para ilustrar y normalizar proporcionalmente, dependiendo de las escalas sociales instaladas (condiciones de edad, género, etnia y clase social).

En consecuencia, si las (hiper) mediaciones pedagógicas pretenden potenciar sujetos y fomentar el acontecimiento a través de prácticas pedagógicas divergentes, esto implica construir currículos y experiencias a partir de las premisas de la inteligencia colectiva (en diálogo con los principios de la educación convergente y la pedagogía de la presencia). Algunas de las premisas centrales de la inteligencia colectiva son: fomentar la cultura de las cualidades humanas; promover la riqueza social mediante la producción de aprendizajes y saberes compartidos; y valerse del ciberespacio como dispositivo de comunicación interactiva y comunitaria, privilegiado para llevar a cabo proyectos colectivos que se inscriben en una nueva economía política del acontecimiento.

En relación con el primer aspecto, es importante subrayar que la inteligencia colectiva es una categoría distinta a la de capital humano. Mientras que la primera fomenta sinergias a partir de proyectos comunes y nuevas posibilidades de vínculo social, favoreciendo el crecimiento de beneficios compartidos, el capital humano es una doctrina de la teoría económica del crecimiento, la cual designa como factor de producción a las personas, dependiendo de variables distintas como la profundidad de sus labores, el grado de formación y su capacidad productiva. La perspectiva ha sido llevada a la educación, al introducir el capital humano como uno de los propósitos centrales de los currículos basados en competencias.

Como se puede apreciar, la inteligencia colectiva plantea una distinción muy importante frente a uno de los sustratos (eidos, según lo expuesto al inicio del apartado) que en la actualidad orienta la política de competencias y estándares en Colombia. Introducir la inteligencia colectiva en la escuela modificaría sustancialmente esta perspectiva, la cual no solo supone la 
preparación de los estudiantes para el sector productivo (ahora transnacionalizado) sino su designación como recurso desde la infancia. A propósito de competencias, la doctrina del capital humano sostiene que cuando aumenta el grado de destreza, experiencia o formación de las personas, la institución económica garantiza mayor y mejor producción.

Para fomentar la inteligencia colectiva en la escuela a partir de uno de los pilares claves (cultura de las cualidades humanas) planteado por Lévy (2004), es necesario fomentar la participación mediante proyectos que involucren saberes acumulados por los niños y niñas así como nuevas dinámicas de articulación y corresponsabilidad. Potencializar la cultura de las cualidades humanas implica reconocer y valorar los capitales culturales que los niños y niñas poseen o que virtualmente están ahí y que pueden ser promovidos. Implica proponer experiencias en las que ellos y ellas cumplan roles que permitan poner en práctica aprendizajes invisibles y formales, apelando a diversas formas de convergencia.

El segundo elemento planteado por Lévy (2004) es promover la riqueza social mediante la producción de aprendizajes y saberes compartidos. Este planteamiento, una vez más, se enmarca en uno de los grandes debates contemporáneos relacionados con la noción de capitalismo cognitivo. Como es sabido, el capitalismo cognitivo es un término que alude al trabajo inmaterial, comprendido como una tendencia reciente en la cual la acumulación de capital opera por la vía del conocimiento, la originalidad y la creatividad.

$\mathrm{Al}$ respecto, Berardi (2003) señala que este fenómeno tiene sus orígenes en los procesos (diferentes pero integrados) que ha suscitado la transformación tecnológica: por un lado, la puesta en red favorece la coordinación de los diferentes fragmentos de trabajo en un único flujo de información y de producción; y por otro, la diseminación del proceso de trabajo mediante archipiélagos de islas productivas, formalmente autónomas, garantiza dependencia y coordinación. Ante la dificultad para calcular el valor de cambio del producto y garantizar su uso y venta exclusiva, el capitalista limita su libre difusión a través de medios jurídicos (patentes, derechos de autor, licencias y contratos) y monopolios (evitar posibilidades de copiar, imitar, reinventar y aprender conocimientos de otros). 
La propuesta de Lévy (2004) no se involucra explícitamente en este problema. Sin embargo, admite que los nuevos mecanismos para existir como humanos y no como simples recursos, implica asumir la inteligencia colectiva como fuente y objetivo de otras riquezas, las cuales pueden ser abiertas e inacabadas. Los ejemplos de esta lucha los proveen con mayor contundencia las experiencias Software Libre, Creative Commons, el Manifiesto Remix y el Movimiento Cultura Libre ${ }^{35}$. Mientras tanto, son varios los esfuerzos de las instituciones y de las transnacionales por restringir las herramientas gratuitas colaborativas y las tipologías crecientes de software social.

De acuerdo con esto, la escuela debe propender por prácticas pedagógicas que preparen a los niños y niñas para esta lucha expresada local y globalmente. Además de una alfabetización digital que incluya el uso y la apropiación de herramientas libres y colaborativas en la Web 2.0, se requieren experiencias que comprometan a los prosumidores en la construcción colectiva de informaciones, piezas comunicativas, proyectos y obras, que se valgan del patrimonio del saber situado en la Web 2.0 para fomentar la creación y alternativas sostenibles frente a los problemas del tiempo presente. Esto corrobora además, que la escuela mientras continúe privilegiando el predominio de la enseñanza del profesor y el uso de textos escolares, lejos estará de la realidad del mundo social y político contemporáneo.

Finalmente, Lévy (2004) incluye la circulación de información, saberes y aprendizajes en la cibercultura como una de las mayores fortalezas de la inteligencia colectiva. Esta fortaleza es la base para llevar a cabo proyectos colectivos que se inscriben en una nueva economía política del acontecimiento. Lévy considera que tanto las tecnologías molares (mediáticas) como las tecnologías moleculares (postmediáticas), basadas en mecanismos de control

\footnotetext{
${ }^{35}$ Como se ha señalado, estos son los movimientos más representativos de la lucha al capitalismo cognitivo. Lawrence Lessig (2004), líder del movimiento Cultura Libre, considera que en las actuales circunstancias, es imprescindible acordar un modelo de flexibilización del Copyright como nuevo paradigma para el desarrollo cultural y científico desde Internet. Apoyado en la perspectiva de Richard Stallman (Software Libre), Lessig plantea la exploración en la Web como una metodología de trabajo descentralizado, colectivo y cooperativo, basado en la granularidad gruesa o fina de cada uno de sus participantes. De este modo surge lo Procomún, comprendido como un espíritu colectivo impulsado por el único beneficio de expandir el saber. Esta expansión requiere que la Web sea asumida como caja de herramientas.
} 
a distancia (hacia las masas y hacia las microestructuras de sus objetos respectivamente), deben ser enfrentadas mediante comunidades inteligentes ${ }^{36}$.

Estos mecanismos se expresan en educaciones fuera de las instituciones, aprendizajes cooperativos en red, proyectos basados en coordinación descentralizada, producción de textos, hipertextos, material multimedia y obras que se distribuyen y comparten. La tradición de la escuela moderna ha fomentado el monopolio del conocimiento en el profesor y el texto escolar. La participación se reduce a simulacros relacionados con el gobierno escolar. El trabajo colectivo pocas veces es gestionado grupal y colaborativamente, dado que generalmente se basa en rutinas escolares. El uso de tecnologías se supedita a la ofimática, y cuando se apela al uso de recursos en la Web, las limitaciones de conectividad desalientan a profesores y estudiantes. Pero además, difícilmente se cuenta con criterios pedagógicos para fomentar redes y comunidades de aprendizaje desde la escuela.

Los procesos más importantes de la inteligencia colectiva, según Lévy (2004), son la escucha, la expresión, la decisión, la organización, la conexión y la visión. La escuela, asumida como comunidad inteligente, tendría como finalidad su propio crecimiento, su densificación, su extensión y su apertura al mundo. Evidentemente estos derroteros requieren de nuevos profesores, nuevos currículos, nuevas prácticas pedagógicas y nuevas prácticas evaluativas. Sin embargo, lo más importante de todo esto es que se requiere una escuela abierta, capaz de poner en escena los principios de la educación convergente y la pedagogía de la presencia.

\footnotetext{
${ }^{36} \mathrm{Al}$ respecto precisa Lévy (2004): «Las técnicas moleculares, finas, a temperatura ambiente, se oponen a las técnicas molares, masivas, quemantes o heladas, a los antiguos procedimientos que apuntaban indistintamente a poblaciones enteras, de reorganización lenta, utilizando selecciones inciertas, combinaciones burdas, de calentamiento, de irradiaciones masivas acumulando pues desechos y desperdicios. En el campo de lo vivo, como en el de la materia o de la información, tendemos hacia modos de acción finos, dirigidos, precisos, rápidos, ahorradores, cualitativos, discretos, calculados y puestos en práctica con precisión, en el momento oportuno, acordes con la evolución permanente de los objetivos y las situaciones».
} 


\section{ELEMENTOS DE LAS (HIPER) MEDIACIONES PEDAGógICAS}

\section{Ambientes de aprendizaje: del aula de clases al colaboratorio}

El aprendizaje en la CDI requiere de la conformación de nuevos ambientes de aprendizaje. Estos ambientes ya no corresponden exclusivamente al aula de clases o al salón de informática. Los ambientes de aprendizaje se han ampliado y deben procurar la convergencia entre las tres culturas enunciadas anteriormente (popular, digital y escolar). De este modo, un ambiente de aprendizaje para la producción de presencia implica explorar tanto los escenarios online como los espacios offline que acompañan la vida de los niños y niñas así como una búsqueda permanente de contextos que favorezcan aprendizajes para la vida.

Un ambiente de aprendizaje, en su carácter contextual, debe ser comprendido como un microsistema inscrito, a su vez, en un sistema social, cultural e institucional. Más que un espacio físico, los ambientes son escenarios en los que confluyen prácticas, lenguajes einteracciones, los cuales operan mediante sistemas simbólicos que se van desplegando en el devenir de la propia praxis. El orden social y cultural que se va cristalizando en las prácticas cotidianas, hace posible la producción de sentido y los intercambios en medio de complejas tensiones entre el conocimiento escolar y el conocimiento del mundo de la vida (cultura popular y cultura digital), entre aprendizajes invisibles y conocimientos formales, y entre lo emocional y lo racional-reflexivo.

Para Edwards (2006) las creencias, expectativas y discursos de los maestros constituyen un marco de valoraciones no siempre explícitas, que tienen gran incidencia en su práctica pedagógica. Esto significa que, en el contexto de la escuela moderna, lo que predomina es la enseñanza más que el aprendizaje. Además la enseñanza, generalmente ligada a la transmisión, está especialmente influida por los referentes valóricos, las cargas emotivas y las condiciones socio-culturales en las que viven los maestros, más que por los dominios de sus saberes disciplinares propiamente dichos. En consecuencia, es muy probable que la comprensión del contexto del aula aún esté asociada con las formas como el profesor ocupó este espacio desde su niñez. 
En esta dirección, repensar la disposición del espacio, de los cuerpos, de los objetos, de las interacciones, así como las posibilidades de generar movimientos $\mathrm{y}$ formas divergentes para habitar el ambiente de aprendizaje, se convierte en una de las tareas fundamentales para avanzar en la producción e implementación de (hiper) mediaciones pedagógicas. Esto indica también la necesidad de des-estructurar el aula de clases y convertirla en un colaboratorio.

El aula de clases es un espacio que no ha logrado ser modificado, pese a las reformas educativas y las perspectivas pedagógicas de orden activo y crítico. La reproducción en la escuela no solo tiene que ver con los contenidos que allí se enseñan. También está asociada con el papel que juega el espacio en el disciplinamiento de los cuerpos y las mentes de los alumnos. Aún persiste la organización de los niños y niñas a través de filas, clasificaciones según rendimiento, composiciones esporádicas de grupos atendiendo a circunstancias al azar, agrupaciones bajo la lógica de lo masculino o de lo femenino, entre otras formas de dominar el espacio del aula. Esto sin detallar el uso de dispositivos materiales y simbólicos que afianzan las relaciones de poder como la tarima en la que se ubica al profesor y el crucifijo que vigila desde algún lugar del aula las acciones de los allí presentes.

La educación convergente y la pedagogía de la presencia requieren de un espacio-tiempo distinto para el trabajo pedagógico. Si bien es imposible eliminar las arquitecturas y los mobiliarios de la escuela moderna, anclados por más de doscientos años en el imaginario de las sociedades occidentales y occidentalizadas, sí es posible ampliar el repertorio de condiciones para favorecer ambientes que garanticen aprendizajes colectivos, así como procesos de escucha, de apreciación, de cooperación y de negociación. Este ambiente, más que un aula (observatorio), debe ser un «colaboratorio».

Los colaboratorios constituyen el contexto más importante de las comunidades inteligentes. En un colaboratorio las comunidades analizan problemas, identifican potencialidades en sus integrantes, generan ideas, expresan propuestas, diseñan obras y las exponen. Mientras que en el aula la disposición de los cuerpos instaura el ritual de la vigilancia, el colaboratorio permite que los sujetos se expresen y actúen con libertad. Mientras que en el aula existe un profesor que enseña a través de un dispositivo que orienta los contenidos, en el colaboratorio se prioriza el aprendizaje, y las fuentes de información y 
conocimiento son múltiples. Mientas que el aula individualiza, el colaboratorio une singularidades y fomenta la experimentación de manera colectiva.

De este modo, concebir el ambiente de aprendizaje como colaboratorio implica articular de manera creativa los escenarios offline y online. Exige que el profesor demarque con claridad los espacios y los tiempos que operan tanto en la interfaz de las pantallas como en los escenarios de la escuela, el barrio o la ciudad. También exige trabajar en red, no solo entre los niños y niñas del mismo curso o del colegio, sino promoviendo conexiones y redes con niños y niñas de otras instituciones, ciudades y países. De este modo, cobra valor el contacto, la exploración de temas y problemas, los aprendizajes y los proyectos en sus participantes.

\section{Contenidos interactivos: del uso del texto escolar} a la postproducción en repositorios Web

Uno de los mayores problemas de la enseñanza en la escuela es la estrechez de los contenidos, generalmente expuestos a través de textos escolares producidos por compañías transnacionales de la industria editorial. Si bien estos textos siguen al pie de la letra las orientaciones curriculares oficiales, su diseño es precario, su estructura persiste en escrituras de izquierda a derecha y lineales, las imágenes utilizadas son básicas, y generalmente, al introducir otras fuentes de información, más allá del contenido establecido, plantean actividades y consultas para que los estudiantes profundicen. Como se ha constatado aquí, estas actividades difícilmente dialogan con sus sistemas de necesidades e intereses.

Las consecuencias del uso persistente de este dispositivo son múltiples. Una de ellas es que el formato está basado en la enseñanza más que en el aprendizaje, asunto que además de limitar las opciones de participación, fomenta la individualización. De otra parte, las actividades planteadas por el profesor se realizan en función del orden del texto, situación que desmotiva y vuelve rutinario el trabajo de aula. Finalmente se trata de un artefacto que termina aislando, y que aunque intente promover actividades y proyectos de aula, no logra dialogar con otras fuentes de información ni posibilita formas de interacción con otros dispositivos y otros sujetos del aprendizaje. 
Esto indica que se requiere reemplazar el texto escolar por la experimentación en y con ambientes virtuales de aprendizaje. Al respecto es necesario hacer una precisión. En la literatura y las experiencias de la educación superior, los ambientes virtuales de aprendizaje han sido llevados al escenario de las plataformas y los procedimientos del sistema e-learning. En este caso, no se trata de transferir el uso de estas plataformas a la educación básica y media. Aplicaciones como las redes sociales, los videojuegos, los canales de video y música, los blogs, los fotologs y las simulaciones, ampliamente exploradas y apropiadas por los niños y niñas, pueden operar como ambientes virtuales de aprendizaje.

Tampoco se trata de exigirle al profesor que deba volverse programador o un experto diseñador de objetos virtuales, pero tampoco se reduce a que use las TIC para exponer un tema (suceso recurrente en la educación desde la puesta en marcha de la tecnología educativa de los setentas). Volviendo a Bourriad (2004) y su perspectiva sobre la postproducción, se requiere de un profesor que se convierta en mediador, en este caso entre los intereses y necesidades de los niños y niñas, las tres culturas y el saber como dispositivo para la inteligencia colectiva. Esto implica tener la capacidad de inventar protocolos de uso divergentes en torno a los modos de representación informales y las estructuras formales existentes.

Según Bourriad (2004), la labor fundamental de la postproducción en la actualidad es fomentar experiencias que busquen apoderarse de todos los códigos de la cultura, de todas las formalizaciones de la vida cotidiana, de todas las obras del patrimonio mundial, y hacerlos funcionar. Aunque estas declaraciones puedan resultar excesivas, esto indica que el profesor debe construir indicios, guías y protocolos para que los niños y niñas orienten sus exploraciones y navegaciones por los escenarios en donde se aborden los temas y problemas que estén estudiando en el contexto del área académica escolar. Aprender a servirse de estas formas de representación supone apropiarlas y habitarlas para resolver problemas.

Esta propuesta plantea, a su vez, tres aspectos que son claves para que el profesor organice los contenidos de su área de estudio. En primer lugar, los temas de su área en un grado específico (orientados por los lineamientos y estándares curriculares del Ministerio de Educación Nacional) deben ser traducidos a problemas. Mientras estos problemas se acerquen más a los sistemas 
de intereses y necesidades de los niños y niñas, mayor significación cobrará para ellos y ellas. Para tal efecto, la metodología de proyectos puede resultar útil en la medida en que, antes de iniciar un tema, el profesor pueda negociar con los niños y niñas y acordar proyectos que puedan ser desarrollados en un tiempo definido (una semana, un bimestre, un semestre, un año escolar). Los problemas derivan en preguntas que se movilizan permanentemente.

En segundo lugar, una vez el profesor reconozca colectivamente los problemas que abordará, debe identificar las posibles convergencias entre diversas tipologías de contenidos que permitan un nivel inicial de estructuración. No se trata de transmitir códigos a través de un dispositivo impreso, audiovisual o electrónico. La estructuración de contenidos tiene varias condiciones: que ordene y potencie los códigos; que propicie el uso de conceptos básicos en secuencias horizontales y verticales; que contribuya a constituir redes de sentido mediante articulaciones y aperturas con conceptos superiores y subordinados; que su modo de presentación permita asimilarlos y retenerlos; que se puedan contextualizar en la vida cotidiana; y que puedan articularse con otros sistemas simbólicos.

Y en tercer lugar, aunque el docente puede producir guías y talleres textuales, debe crear preferiblemente repositorios de información en la Web (mediante sitios ya existentes y enlaces clave) con sus respectivos protocolos. La idea es que tanto el repositorio como los protocolos de uso, permitan a los estudiantes explorar los contenidos, resolver los problemas e interactuar de diversas maneras: individual y/o grupalmente; en tiempos cortos y/o largos; en espacios cerrados y/o abiertos; en entornos audiovisuales y/o virtuales; a través de la interacción con otros contenidos; utilizando datos del contexto inmediato; resolviendo preguntas progresivamente; generando procesos de autoevaluación y autorregulación permanentes; estableciendo metas; definiendo alternativas de seguimiento con sus pares y el profesor ${ }^{37}$.

Además de estas condiciones de posibilidad -que deben ser tenidas en cuenta a la hora de estructurar los contenidos- aspectos como la interdisci-

${ }^{37}$ Esta perspectiva corrobora la formulación de Martín-Barbero (1999, p. 128): «Los modelos comunicacionales subyacen a las diversas matrices culturales y pedagógicas, de allí la cuestión de mirar la comunicación desde adentro de los procesos y las prácticas educativas; y no como mera experiencia exterior (de ayuda, modernización o adorno) a lo pedagógico». 
plinariedad, el diseño estético y técnico del contenido, así como la interacción profesor-estudiantes, estudiante-estudiante, estudiante-contenido, profesor-contenido, orientan la posibilidad de una mejora continua del soporte. Finalmente, este proceso modifica la noción de enseñanza y de conocimiento, en la medida en que promueve otras relaciones entre sujeto-sujeto y sujeto-conocimiento. El ingeniero del mundo es aquel que dispone las condiciones para fomentar la exploración, la colaboración y la inteligencia colectiva. El profesor debe convertirse en este ingeniero de mundos posibles que actualmente requiere la educación.

Prácticas pedagógicas interactivas: de la enseñanza de temas a la transmediación pedagógica

El análisis de las prácticas pedagógicas ha sido uno de los objetos de estudio que mayor inquietud ha generado en los investigadores de la educación y la pedagogía en las últimas décadas. Más allá de las categorías analíticas para abordar la relación entre prácticas y discursos o entre prácticas y uso de dispositivos para enseñar, este principio plantea una idea simple sugerida por el profesor Martín-Barbero: si las nuevas generaciones leen, escriben y piensan diferente, es muy probable que aprendan de otras maneras. Por esta razón, una vez abordados los ambientes (del aula a los colaboratorios) y la estructuración de los contenidos (interactivos y basados en la postproducción), aquí se presentan algunas aproximaciones que favorecerían la apertura de nuevas prácticas pedagógicas.

Este principio descansa en tres consideraciones: las intenciones del profesor para fomentar determinadas prácticas; el carácter hipermedial e interactivo de los contenidos que impulsan la experiencia; las acciones, producciones y modos de difusión que han de desarrollar los niños y niñas mediante la práctica. En relación con la primera consideración, es importante insistir en que ninguna práctica pedagógica puede adelantarse sin ninguna intencionalidad. Como se mencionó al inicio, la acción pedagógica suele estar acompañada de intereses que, según Shirley Grundy (1994) (apoyada en Habermas), se sintetizan en intereses técnicos, prácticos y emancipadores.

Dado que la nueva educación parte del propósito de lograr convergencias y producción de presencia mediante experiencias que afecten la vida de los participantes, según esta taxonomía el trabajo colaborativo y creativo debe 
servir para producir significados compartidos y proponer alternativas a los graves problemas de exclusión y desigualdad del tiempo presente. Mientras que el uso de las Tic -asumido como medio de exposición para reemplazar los sistemas de conocimiento canónicos- remitiría al interés técnico, el fomento de prácticas colaborativas y creativas a través de comunidades inteligentes coincidiría con los criterios de los intereses prácticos y emancipadores expuestos por Grundy (1994).

De esta manera, los aprendizajes producidos a partir de las dinámicas planteadas hasta el momento, deben enmarcarse en intencionalidades que busquen develar los problemas, interpretarlos y actuar sobre estos. Para Grundy (1994) la praxis, comprendida como fundamento de la emancipación, implica actuar sobre el mundo de contradicciones que inciden en las necesidades y aspiraciones de las personas. Se trata de una práctica capaz de incidir en la producción de sistemas de significados, pero situados en contexto.

Por esta razón, apoyados en las premisas del aprendizaje invisible y la educación expandida, lo importante no es el artefacto ni la conectividad en sí mismos. Todos los objetos de estudio (desde las matemáticas hasta la biología y la filosofía) han de servir para formar mejores personas e incidir en la conquista de tres aspectos clave para la vida: construir proyectos de vida posibles; contar con condiciones de vida dignas basados en derechos; y vivir sin humillaciones.

La segunda consideración asociada con las nuevas prácticas pedagógicas se centra en el carácter hipermedial e interactivo de los contenidos que impulsan la experiencia. Como se ha señalado hasta el momento, la pedagogía de la presencia implica fomentar las condiciones necesarias para producir experiencias en la educación y no solo cumplir con rutinas para regular los tiempos y espacios en el escenario escolar. Por esta razón, fomentar experiencias implica considerar las transmediaciones como entornos, a la vez que instrumentos, para potenciar aprendizajes para la vida.

Además de acudir al océano de posibilidades de información disponible en la Web 2.0 -previamente organizado en los repositorios de postproducción (orientados por criterios para explorar y seleccionar datos)-, las prácticas pedagógicas deben estimular la interpretación de la realidad y la producción. En las actuales circunstancias no tiene ningún sentido para los niños y niñas 
trabajar en temas que no afecten su vida ni puedan convertirse en productos para ser compartidos y provocar reacciones. Por esta razón, mediante el acercamiento a los repositorios, a través de los protocolos y guías de navegación, los estudiantes podrán decodificar, interpretar y producir. Estas formas de producción pueden variar (textos sencillos, historietas, hipertextos, hipermedias, videos, medios de comunicación alternativos, obras artísticas).

Con un repertorio amplio de conocimientos, habilidades y actitudes conquistados por esta vía, los niños y niñas podrán luego acercarse a redes o coordinarlas; estas pueden llegar a compartir intereses similares. En el contexto de dichas redes, será posible compartir lo producido y avanzar de manera colaborativa en las preguntas que estos temas y problemas exigen, distribuyendo actividades y asignando roles. Bajo los intereses prácticos y emancipadores señalados anteriormente, la red puede convertirse en comunidad inteligente, en la medida en que puede llegar a interpelar el orden dado.

Para tal efecto se requieren, más que instrumentos de conocimiento, entornos de aprendizaje. En algunos modelos pedagógicos muy conocidos como el aprendizaje significativo, los instrumentos más difundidos son los mapas conceptuales y los diagramas de carácter heurístico. En este caso no se proponen instrumentos de esta naturaleza, sino más bien entornos transmediáticos, que deberán convertirse en el soporte clave para el desarrollo de los proyectos colaborativos en sus distintas fases. Este soporte plantea dos principios básicos: debe integrar códigos textuales, visuales y sonoros; y debe articular medios, contenidos, formatos y géneros para profundizar en la comprensión y la producción.

El profesor debe coordinar la actividad rizomática de la comunidad de aprendizaje, debe observar la participación de cada integrante, debe seguir los grados de avance en los procesos de interpretación y de producción de la comunidad, y debe apoyar el funcionamiento de las redes. Dado que este ambiente no se consigue espontáneamente, el profesor debe organizar la acción de los equipos de trabajo mediante un sistema de interrogación metódica del entorno transmediático. Este sistema debe situar indicios, preguntas y respuestas que le den movilidad al proyecto y que garanticen modificaciones en la comprensión propia del intérprete, evidenciando así sus límites y estableciendo nuevas aperturas. 
La tercera consideración que favorece el desarrollo de nuevas prácticas pedagógicas en la educación convergente y la pedagogía de la presencia se centra en la importancia no solo de interpretar y producir mediante los entornos transmediáticos, sino de difundir e interactuar alrededor de lo que se produce. Esto implica un acento fuerte en la difusión y experimentación. Para tal efecto es conveniente recordar que, tanto las simulaciones como la experiencia estética de postproducción, plantean modos de inmersión que hacen posible el acontecimiento y ciertos grados de libertad para experimentar, decidir y proyectar mundos posibles.

El trabajo colaborativo de un grupo de niños y niñas corrientes, bajo los presupuestos planteados hasta el momento, deben profundizarse y expandirse. Esto significa que si en un momento dado, un grupo de niños y niñas trabaja alrededor de videojuegos o simuladores que exigen recorridos y toma de decisiones, se esperaría en un siguiente momento que sean capaces de relacionar los contenidos y niveles de esta interfaz con situaciones de su vida institucional y comunitaria. También, se podría esperar que propongan nuevos proyectos para experimentar con otras aplicaciones y formatos. Estos grados de experimentación implicarían trabajar en función de la comunicación y difundir lo aprendido.

Apoyados en Cobo (2010), se puede señalar que estas prácticas pedagógicas se inscriben en perspectivas que proponen integrar la educación expandida y la cultura digital. Esta articulación se caracteriza por la organización en red, el trabajo colectivo, la convergencia de medios y el copyleft. Aunque en la actualidad la mayor parte de estos procesos no se incorpora en los sistemas educativos convencionales, la nueva educación ha de acercarse a estas realidades bajo los principios de la educación convergente y la pedagogía de la presencia.

De este modo será posible que surjan proyectos artísticos, científicos, comunicacionales y educativos (con rasgos culturales, sociales, digitales y audiovisuales al mismo tiempo). Aunque es cierto que la educación puede suceder en cualquier momento y en cualquier lugar, la escuela debe ser el espacio social y simbólico donde los niños y niñas cuenten con esta oportunidad y se preparen para las luchas contemporáneas no solo por el conocimiento, sino también por la vida y el territorio. 
De este modo, la (hiper) mediación pedagógica es un pretexto para alcanzar sentidos y prácticas deliberativas, en las que un entorno favorecedor de interacciones, basado en reglas de juego precisas, que se van legitimando y reconfigurando en la práctica, conducen a la apropiación, la acción colectiva, la producción de inteligencias colaborativas y la apertura hacia la creación.

Las comunidades no son meras agrupaciones de individuos que se congregan para realizar tareas conjuntas. Las comunidades (de práctica, de deliberación e inteligentes) adquieren propósitos comunes, intereses compartidos y diversos canales de interacción para resolver problemas. Los saberes se comparten, fluyen en los entornos de comunicación y cada descubrimiento (individual o grupal) es motivo de orgullo para todos. La comunidad es un camino para potenciar al sujeto y asumir que las subjetividades colectivas orientan la acción social y política bajo importantes dosis de solidaridad y creatividad. 
El cierre de este trabajo no se constituye en un capítulo de conclusiones en sentido estricto. Se trata de un epílogo que busca presentar de manera reflexiva no solo las lecciones aprendidas luego de un recorrido de varios años intentando comprender este fenómeno, sino un conjunto de apuestas, en este caso pedagógicas, políticas y epistemológicas, que pueden ser declaradas tras los resultados de la investigación. La primera parte presentará algunas perspectivas que una vez más constatan la necesidad de repensar la educación a partir de la emergencia de nuevas subjetividades en los niños y niñas. La segunda expone, a partir del concepto infancias, la demarcación de algunos criterios para los estudios sobre los niños y niñas del tiempo presente.

\section{¿Comunicación-educación digital emancipadora?}

Se ha insistido a lo largo de este trabajo que la distancia entre las experiencias de los niños y niñas (las cuales acontecen en el contexto de la nueva cultura visual, las transmediaciones y la comunicación digital interactiva) y las rutinas del mundo escolar se profundizan y traen varias consecuencias: un divorcio progresivo entre los conocimientos escolares que buscan ser enseñados y capitales culturales producidos por estos sujetos en la comunicación y la cultura; rituales que se simulan entre las partes (contrato didáctico); y pérdida de legitimidad de la institución y de la figura del profesor. Este pro- 
blema está asociado con la persistencia de un sistema educativo que se basa en la transmisión de contenidos y que se resiste a cambiar dado el riesgo de perder su estabilidad y control.

Más allá de los debates entre las posturas tecnofóbicas o tecnofílicas, este estudio evidenció que estas generaciones han nacido y crecido en el contexto semiótico y social de un nuevo programa cultural, que se reafirma en la cultura audiovisual y en las transmediaciones. El advenimiento de otras visualidades, sonoridades e inmersiones virtuales hace que se sedimenten otras percepciones del tiempo y el espacio, cuya base no es la causa y el efecto de los hechos sino la emergencia de procesos cognitivos, estéticos, sociales y afectivos que privilegian la interacción con los otros y con el mundo mediante el impulso de dimensiones asociativas, sintéticas e intuitivas.

De otra parte, también se constató que el tránsito de los niños y niñas por la comunicación digital interactiva (desde aquellos que están a toda hora conectados como Maka, hasta aquellos que van de vez en cuando al Café Internet del barrio ante la ausencia de conectividad en su hogar, como Dany) hace que se configuren otras racionalidades y saberes. No se trata de un determinismo sino de un acontecimiento: algo que puede ser creado en el orden de lo posible, según Lazzarato (2006). Las racionalidades hipermediales e interactivas, así como los capitales culturales producidos (en torno a los usos de la interfaz, a los contenidos de las aplicaciones de la Web y a la intertextualidad del prosumidor) son potencia y mundo posible. Su fortaleza es que promueven la polifonía de voces y el plurilingüismo, apelando a las bellas palabras que promovió Bajtin (1997) hace algo más de cincuenta años.

Vale también precisar que estos modestos descubrimientos permitieron considerar la presencia de otras subjetividades. No se trata de las subjetividades que son fabricadas tras la gestión de prácticas de saber-verdad y de saber-poder que operan en el mundo de las instituciones disciplinarias, sino de subjetividades que se cristalizan en experiencias de diverso orden, entre ellas las comunicativas (aquellas que tienen que ver con lo común y lo múltiple). En consecuencia, son subjetividades que operan en una frontera cultural que entrecruza instituciones (familia, escuela e iglesia) y escenarios de afectividad, emoción y riesgo. En estos espacios los sujetos viven el presente, la instantaneidad y sucesos efímeros, que seguramente entremezclan consumo, estéticas de la vida y comunicación. 
Sin embargo, lo más interesante de estas subjetividades es que muestran cómo en esa frontera está germinando un proceso de constitución de sujetos, que no solo advienen a través de la experiencia de sí sino también a través de la experiencia del otro. Un otro que se incorpora en el mundo del yo sin menosprecio y que exige responsabilidad (no jurídica sino ontológica y congénita). De este modo, subyace la experiencia del sujeto no como acción instrumental, a propósito del uso de dispositivos de comunicación, sino como acto ético. En este acto, según Bajtin (1997), no hay adhesiones o subsunciones para inferiorizar al otro. Se trata de un acto en el que surgen posiciones y puntos de vista, los cuales se ponen en escena mediante la captura de capturas y la fuga de fugas.

La construcción de nuevas percepciones a partir de este ecosistema comunicacional en el que han crecido estos niños y niñas es un culmen de experiencias, no solo por su carácter espectacular o porque se configura un nuevo sensorium (homo simbolicus, según Cassirer, 2003), sino porque, tras cada acto, se genera la muerte figurada del sujeto. Una muerte que implica abandonar lo que éste era y creía porque es capaz de dejarse asombrar por nuevos ordenamientos que lo conminan a hacer recomposiciones. Según Benjamin (2009), esta ruptura hace posible acontecer y, seguramente, existir de otras maneras.

Como se apreció a lo largo del estudio, las interacciones de los niños y niñas (comunes y corrientes) en y con los mundos transmediáticos de la televisión y la filmografía contemporánea, así como las prácticas que generan en los intersticios de la CDI, se constituyen en condiciones de posibilidad para entretenerse, socializar, conocer y crear. Si bien las fuentes sociales y culturales de estos nuevos razonamientos y capitales están atravesadas por el mercado y el capitalismo cognitivo (Lazzarato, 2006) y de la afectividad (Jenkins, 2008), las potencialidades de las formas simbólicas subyacentes a estas experiencias son explícitas y crecientes.

Lo más importante de este escenario no son los objetos en sí mismos (pantallizados e hiperconectados) a los que las personas puedan acceder, sino las culturas de uso que los sujetos producen cuando piensan y actúan en red, apoyados en estas mediaciones. Ahí es donde la escuela moderna (centrada en la enseñanza de contenidos a través del modelo transmisionista) se vuelve improcedente, pues individualiza, (des)califica y ancla el imaginario del saber en el profesor, el texto escolar y eventualmente en la enciclopedia. 
No hay fórmulas para resolver este problema. Las estimaciones planteadas en esta tesis buscan provocar a las instituciones de protección y de educación, así como a los profesores con el fin de generar otras posibilidades, más allá del lugar común «uso de las Tic». No son prescripciones para formular estrategias didácticas. Son principios y criterios que parten de la comprensión del programa cultural, expresado en forma de acontecimientos en el contexto del tiempo presente, así como de las experiencias de los niños y niñas en el mundo de la cDI. Se trata de un camino distinto, pues generalmente los estudios de la educación y la pedagogía no salen del espacio escolar. Se investigan asuntos relacionados con la cultura escolar o con sus factores asociados (tema preferido de los estudios de los organismos internacionales). Este estudio intentó comprender las otras culturas que recorren estos mutantes para considerar posibles convergencias.

Aunque es claro que la alfabetización digital de los profesores es una tarea prioritaria (asunto que actualmente están adelantando las entidades estatales, por ejemplo el Ministerio de las Tic), la escuela puede asumir en serio el desafío de construir la pedagogía desde la comunicación. De ahí deriva el título de este ítem (comunicación-educación digital emancipadora), que no es otra cosa que estimular a los maestros y a los investigadores de la infancia, la comunicación y/o la educación para que avancen en experiencias y estudios que demarquen con mayor precisión el carácter emancipador de la comunicación-educación.

Hacia la década del veinte del siglo pasado, Celestine Freinet ya lo había intuido. Su apuesta no fue común y, dada su persistencia, fue duramente criticado al principio. En lugar de enseñar contenidos a los niños más pobres del sur de Francia, y luego de haber concluido que las herramientas de la Escuela Activa (en cabeza de Decroly) eran muy costosas y que no podía adquirirlas, introdujo en el aula una imprenta para que sus estudiantes produjeran un periódico. Con el tiempo, además de contar con un consejo de redacción y corresponsales en el pueblo cubriendo acontecimientos, el periódico salió de la escuela y se convirtió en un producto público, no solo para los habitantes de aquel pequeño pueblo, sino para estudiantes de otras escuelas y localidades. Estos últimos también se animaron a escribir sobre sus necesidades e intereses.

Esta pequeña anécdota permite comprender que el gran problema de la escuela moderna es que pretende privatizar y controlar el conocimiento. Dado 
su marcado interés por sostener el orden social a través de los rituales disciplinarios (analizados en algunos capítulos de este trabajo), el conocimiento que busca enseñar y evaluar se convierte en dispositivo de poder, en lugar de ser asumido como medio de liberación. Freinet muestra que el conocimiento es un producto social y que debe ser colectivizado, intercambiado y comunicado. Lo más importante, según esta breve historia, no era la imprenta sino las prácticas y los valores puestos en juego al definir un proyecto común: un periódico producido por los niños que intentaba retratar el mundo de la vida, colocando en diálogo la cultura escolar y la cultura popular. Esta experiencia muestra que es posible hacer pedagogía en y con la comunicación.

La genialidad de Freinet no está en haberse anticipado al campo comunicación-educación, el cual ha acompañado la mayoría de las reflexiones y propuestas de esta tesis. El gran aporte de este pensador está en haber entendido que aquello que se conoce (por básico que sea) debe ser compartido, distribuido y socializado. Mientras que la ciencia se pregunta cómo construir conocimiento en una disciplina, campo o paradigma, la pedagogía debe preguntarse cómo el sujeto que aprende hace inteligible la realidad para comprenderla y transformarla. En la construcción de aquellas gramáticas que hacen posible a un niño aprehender el mundo natural, físico o social, la mediación implementada debe permitirle comprender los fenómenos y divulgar lo que sabe.

Como se pudo observar en la última parte de este trabajo, las mediaciones pedagógicas que han de construirse para aquellos sujetos que devienen comunicativos e inmersos en nuevas experiencias culturales-comunicativas, constituye una de las tareas fundamentales para la educación del tiempo presente. Pedagogía de la presencia, educación convergente e hipermediaciones pedagógicas conforman una plataforma posible para crear nuevas educaciones y pedagogías que asuman la opción por la construcción de lo común (compartir algo) desde un lugar distinto. No se trata de lo común como lo homogéneo, sino como la constatación de una nueva esfera pública que implica comunicación y educación. Esta esfera involucra sujetos, objetos y especialmente nuevos repertorios culturales, los cuales provienen de experiencias humanas, sedimentadas a partir de la constitución de subjetividades emergentes (hipermediales, interactivas, divergentes...).

La mayor potencialidad de estas subjetividades evidenciadas en los niños y niñas que participaron de este trabajo no es solamente su propensión existen- 
cial a interactuar y compartir lo que sienten. Tal vez lo más importante es el valor que cobran las fuentes de información y conocimiento que les permiten leer, escribir, pensar y actuar de otros modos. Los niños de Freinet también lo descubrieron: hacer el periódico les implicó indagar y acceder a nuevas fuentes de información, convirtiendo el aprendizaje en un hecho social. En los niños y niñas de este estudio, los aprendizajes (invisibles según Cobo y Moravec, 2010) que se producen en el mundo de las redes y las transmediaciones son experiencias y acontecimientos. Su base es la polifonía de voces (Bajtin, 1997), una suerte de tonalidades que incluyen no solo percepciones sino composiciones.

Evidentemente, el profesor que enseña contenidos, transmite información y busca corroborarla mediante el examen, difícilmente comprenderá lo que está pasando con las infancias. Por esta razón, se requiere deconstruir las prácticas pedagógicas convencionales y convertir los espacios y los tiempos de la escuela en ambientes de aprendizaje colectivos y colaborativos, acorde con las subjetividades de sujetos mutantes, nómadas y prosumidores. Asimismo, es fundamental transitar del aula-observatorio al colaboratorio interactivo, del texto escolar a la postproducción en repositorios Web, y de la enseñanza de temas a la transmediación pedagógica.

Seguramente fue evidente para el lector de este trabajo la insistencia en tener precauciones frente a discursos y prácticas que, en nombre del mercado, prometen participación, democracia y libertad. El tema es tan complicado que hoy se conocen con precisión varios investigadores y centros académicos que trabajan abiertamente con corporaciones, las cuales han creado grandes dependencias para investigar estos fenómenos y realizar grandes eventos, capaces de mostrar las bondades de sus productos y servicios. Algunos de estos investigadores han planteado que la escuela ya no debería existir y que las personas podrían resolver su alfabetización y conocimientos en el contexto de un mundo virtual armonioso, fuente de extrema gratificación.

Dada la existencia de estos sucesos, es necesario indicar que lo planteado aquí no sugiere terminar la escuela o presagiar el advenimiento de la posescuela y la posuniversidad. Aunque es un camino difícil, estos hallazgos permiten considerar un desafío clave para la pedagogía: el paso de la comunicación digital interactiva y sus convergencias con la educación, a una comunicación-educación digital emancipadora. Podrían ser tres los ele- 
mentos que prefiguran esta apuesta educomunicativa:La apropiación social del conocimiento en los niños y niñas del tiempo presente es posible cuando se les potencia como prosumidores, sujetos portadores de experiencia y con capacidad de agencia. Para tal efecto, se requieren prácticas pedagógicas que promuevan la generación de productos comunicables, que puedan ser puestos en el escenario de lo público y que contribuyan a descentrar al sujeto, esto es, que sea capaz de asumir un rol distinto al de estudiante.Educar a las infancias en el tiempo presente implica la generación de múltiples interacciones. Luego la riqueza de una escuela no estará solamente en su sofisticación tecnológica o en la formación de sus profesores, sino en la trama de flujos comunicacionales que pueda potenciar a través de los ambientes, las experiencias y las opciones de liberación generadas en sus prácticas pedagógicas. Según Ferrés (2008), el profesor debe ser también un comunicador.

Aunque tuvo algunas aproximaciones, este estudio no logró abordar con profundidad lo que podría ser llamado comunicación-educación digital emancipadora. Para tal efecto, se presenta un listado de asuntos pendientes por trabajar para futuras investigaciones:

1. Es necesario recuperar elementos de la educación popular y de las pedagogías críticas para ponerlos en diálogo con estas propuestas que involucran tecnologías digitales, cibercultura, hipermediaciones y transmediaciones. Se requiere abordar mediante investigaciones empíricas cómo la comunicación puede operar en tanto proceso, mediación y experiencia para la emancipación. Es tiempo de reconocer y analizar experiencias educativas (dentro y fuera de la escuela) que se hayan arriesgado a construir otros currículos, otras prácticas pedagógicas y otras formas de evaluación desde la comunicación para emprender trayectorias de agenciamiento educativo y político.

2. Es necesario actualizar el campo comunicación-educación desde el punto de vista epistemológico. Como se apreció, este es un legado construido en la región que proporciona pistas importantes para afectar la educación. Por ejemplo, esta tesis plantea que la cultura audiovisual y transmediática así como las prácticas de los niños y niñas en la cDI pueden interpelar la escuela y movilizar su transformación. Es necesario continuar haciendo búsquedas que no pierdan de vista estas dos categorías como ejes de indagación científica, pues como se ha señalado, los discursos sobre la implementación 
de tecnologías (sin un telos político, filosófico y pedagógico) se han tomado la escuela y, probablemente, han generado más confusiones de las que ya existían.

3. Es muy importante avanzar en estudios empíricos que analicen a fondo cómo se produce la sensorialidad, la actividad cognitiva y la dimensión estética del sujeto cuando interactúa con distintos entornos digitales. Probablemente este tema requiera de trabajos interdisciplinarios entre la pedagogía, la comunicación y las neurociencias. Aunque es sabido que estos temas se están adelantando rigurosamente en varios países del mundo, es fundamental abordarlos en nuestro país.

4. Es necesario hacer investigaciones que observen la naturaleza de los aprendizajes invisibles y de las experiencias de educación expandida en los niños, niñas y jóvenes. Este trabajo no asumió como verdadera la premisa de la existencia de los nativos digitales. Parcialmente se consideró que las infancias y los jóvenes han nacido y crecido en medio de un entorno audiovisual y digital que ha afectado sus modos de pensar y actuar. No obstante, es necesario avanzar en estudios que permitan observar las prácticas, interacciones y producciones de estos sujetos en entornos no escolares de manera mucho más detallada, de modo que pueda estimarse su articulación con las prácticas pedagógicas escolares.

5. Finalmente, es fundamental profundizar en la producción de sistemas simbólicos, socialidades y procesos de creación en los niños, niñas y jóvenes. Esto implicaría la incorporación de metodologías que permitan observar detalladamente el valor de la experiencia estética, las músicas y el diseño, alrededor de temas y problemas planteados parcialmente en este trabajo, como el rémix y la posproducción.

\section{¿Es posible estudiar las infancias más allá de las prescripciones?}

Asumir la noción infancias implica reconocer la existencia de múltiples formas de transitar la niñez. Éstas no solo remiten a la producción de marcos explicativos para conocer su estado y proceder a su encauzamiento. Se trata de una categoría que propone explorar la urdimbre de experiencias que le dan sentido a la existencia de estos sujetos, en el marco de sus relaciones con la sociedad, la política, la economía y la cultura. El planteamiento invita a supe- 
rar su anclaje naturalizado a la escuela y la familia como únicos escenarios en los que es posible gestionar la vida y construir subjetividades.

El paso de la infancia moderna a las infancias trae consigo otras implicaciones. En primer lugar, al plantear el plural como interpelación al vocablo in-fantis (del latín sin voz), se disloca la nominación que asocia la imagen del niño con la incapacidad y su falta de participación en la sociedad, la cual dejaba anclados su cuerpo y mente a una objetivación que lo desactivaba de la historicidad y la producción de universos de sentido. Aunque etimológicamente en la palabra infancia existe una intención enunciativa que niega su opción a pensar por sí mismos y participar en el mundo, las infancias deconstruyen el término moderno y su significado. El concepto plantea una resemantización que aboga por un lugar de enunciación distinto, el cual se aparta de la concepción esencial y universal del niño y sus respectivos correlatos.

Infancias es un término que se distancia de las clasificaciones propias de la psicología evolutiva, tales como niñez, adolescencia, juventud, adultez y vejez. Al situarse en los estudios sociales y culturales toma como ejes de análisis las dimensiones histórico-culturales y políticas de la sociedad, así como la producción de sentido y de presencia que opera en las experiencias de estos sujetos en el mundo de la vida.

En segundo lugar, el plural tiene como propósito reconocer la diversidad de posibilidades existenciales que los niños y niñas expresan, las cuales los conducen a la construcción de mundos de vida (Muñoz, 2006), en oposición a su emplazamiento en un proyecto de vida lineal, secuencial y ordenado (en tanto designación prototípica del ideal moderno del niño). Esto significa que, en medio de condiciones atravesadas por la desigualdad económica y la exclusión socio-cultural, los niños y las niñas deben ser reconocidos por las maneras como usan y apropian el mundo, así como por los universos de significado que producen en su experiencia social y subjetiva.

La construcción social y subjetiva de las infancias en el tiempo presente incluye elementos contextuales fundamentales:

1. Surgimiento de otros registros y condiciones en los que se produce la subjetividad. 
2. Un papel central de la cultura y la comunicación como vector de la política y la economía.

3. Reconfiguraciones perceptuales del tiempo y el espacio como nueva bitácora para la orientación del vínculo social y el aprendizaje.

4. Un momento aún no finalizado de transición en el que los sistemas de valores se modifican. Por esta razón, la mutación es una metáfora clave para analizar el tiempo presente.

Más allá de ser considerada una continuación de la evolución cronológica del niño en la historia y su actualización en el presente, infancias es una categoría analítica que propone a los investigadores centrar la atención en las experiencias de estos sujetos en el mundo de la vida. Por lo tanto, asumir la expresión infancias como concepto exige del investigador la comprensión de los fenómenos adscritos a las experiencias, las formas de socialización, los registros de la sensibilidad, los procesos que hacen visible la producción de saberes y la creación, entre otros aspectos ligados al devenir de los niños y las niñas, a propósito del surgimiento de otras formas de percepción social.

Tanto la puesta en escena de este concepto como las conclusiones surgidas de esta tesis, permiten afirmar que es necesario producir otros sistemas de conocimiento acerca de los niños y las niñas, que tomen distancia de las relaciones entre saber y poder que fomentó la modernidad en sus distintos momentos, atendiendo a la diversidad de estrategias y dispositivos aplicados. Para tal efecto, se requiere producir conocimientos sobre las infancias teniendo en cuenta, al menos, cinco condiciones básicas que subyacen de este camino recorrido:

- Se hace necesario construir saberes que no operen como prescripciones, deber ser o intervenciones. Es importante tomar distancia de la lógica universal, dicotómica y estructural de los sistemas de conocimiento sobre los niños y niñas. La intención de fomentar un modelo ideal con tendencia a normalizar e igualar a todos aquellos que se distancien de éste, hace que las disciplinas y campos ocupados de este objeto - sujeto- de estudio establezcan formas de aniquilamiento de la diferencia y fomenten procesos de subjetivación ligados al poder de los discursos de verdad (procedentes de los expertos, de las instituciones $\mathrm{y}$, recientemente, del mercado). 
- Se requiere de saberes que propongan marcos explicativos innovadores, capaces de ofrecer comprensiones sobre las distintas relaciones entre las condiciones de emergencia de estos sujetos, expuestas frecuentemente en universos complejos de expresiones de subjetividad y las tramas del tiempo y el espacio en las que viven. Esto indica que hay que superar las concepciones de etapas de desarrollo y grupo etario, como preparación para el futuro, planteadas recurrentemente por los saberes modernos. Sin que esto indique que el tiempo futuro no sea algo importante para la vida de las personas y para las sociedades, es claro que para los niños el valor de sus mundos de vida está relacionado con lo que acontece en su presente.

- Es importante producir saberes sobre y con los niños, que permitan observar los cambios, las transformaciones y, en general, las mutaciones. La redefinición de lo que significa ser niño o niña en una época de rupturas, pero también de continuidades, es una labor fundamental para interrogar las instituciones y los dispositivos creados para gobernarles.

Más allá de una sentencia acerca de la inminente desaparición de las instituciones de formación y de protección, es importante producir saberes que permitan comprender la distancia entre la subjetividad moderna (explícitamente fomentada por la escuela y las instituciones de protección) y las subjetividades emergentes (producidas en otros escenarios de aprendizaje y socialización). Conocer estas distancias contribuirá a repensar la validez y el sentido de estos espacios y procedimientos (intervención psicosocial y enseñanza de contenidos), aún anclados en el proyecto moderno y sus correlatos (sujeto racional, ciudadanía, desarrollo).

- Es necesario producir saberes que desnaturalicen la relación entre infancia, escolarización y desarrollo. El énfasis en presentar a los niños como naturalmente vinculados a la escuela y objeto de modelos teleológicos que los disponen en el tiempo, alrededor de nociones como acumulación, niveles, orden y secuencias, ha sido parte de un marco explicativo cuyas consecuencias han desencadenado la subalternización de estos sujetos y un particular modo de desactivación social y política. La identificación de experiencias, saberes, sensibilidades y socialidades, como expresiones de nuevas subjetividades, puede contribuir a darle un lugar distinto a estos sujetos en términos de agencia, creación y producción de mundos posibles. 
- Si bien, las perspectivas críticas han mostrado cómo han operado las fuerzas de constitución procedentes de las instituciones disciplinarias (sociedad disciplinaria) y/o el mercado (sociedad de control), se requiere de saberes que valoren las experiencias de estos sujetos y que se introduzcan en sus mundos de vida, como condición de posibilidad para identificar los rasgos y modos de efectuación de su propia subjetividad.

Por ahora, lo más importante es que el diálogo continúe. Seguramente tendremos muchas alternativas para comunicarnos. Ahora, el lector tiene la palabra... 
Adorno, T. y M. Horkheimer, M. (1967, 2007). Dialéctica de la ilustración. Madrid: Akal.

Adorno, T. y M. Horkheimer, M. (1981). La industria como cultura: ilustración como engaño de las masas. En: J. Curran, M. Gurevitch y J. Woollacot (Eds.). Sociedad y comunicación de masas. México: FCE.

Amador, J. C. (2009). La subordinación de la infancia como parámetro biopolítico y diferencia colonial en Colombia, 1920-1968. En: Revista Nómadas 31. Bogotá: IESCO, Universidad Central.

Amador, J. C. (2010). El vacío de la infancia y la juventud. En: A. Serna y D. Gómez (Comp.). Derechos humanos y sujeto pedagógico. Retóricas de la formación. Bogotá: IPAZUD, Universidad Distrital.

Amador, J. C. (Comp.), (2012). Infancias, cibercultura y subjetividad: modos de ser y estar en el mundo a través de las pantallas. Bogotá: Ed. Universidad Distrital.

Aparici, et ál. (s.f.). Educomunicación: más allá del 2.o. Barcelona: Gedisa.

Arendt, H. (1991). La crise de la culture. Paris: Gallimard.

Arfuch, L. y Catanzaro, G. (Comp.), (2008). Pretérito imperfecto: lecturas críticas del acontecer. Buenos Aires: Prometeo Libros.

Arfuch, L. (2007). El espacio biográfico. Dilemas de la subjetividad contemporánea. Buenos Aires: FCE.

Austin, J. (1969, 1991). Cómo hacer cosas con palabras. Barcelona: Paidós.

Asociación Colombiana para la Investigación de Medios (АCIM) (2009). Estudio Nacional de medios 2009. Bogotá: AcıM. 
Bajtin, M. (1997a). Hacia una filosofía del acto ético. En: M. Bajtin. Hacia una filosofía del acto ético. De los borradores y otros escritos. Barcelona: Anthropos.

Bajtin, M. (1997b). Autor y héroe en la actividad estética. En: M. Bajtin. Hacia una filosofía del acto ético. De los borradores y otros escritos. Barcelona: Anthropos.

Baricco, A. (2008). Los Bárbaros, ensayo sobre la mutación. Barcelona: Anagrama.

Baudrillard, J. (1984, 2009). La sociedad de consumo. Sus mitos, sus estructuras. México: Siglo XXI.

Becerra, M. (2000). De la divergencia a la convergencia digital. En: Revista de Estudios de Comunicación 8. País Vasco: Ed. Universidad del País Vasco.

Benjamin, W. (2007). Primeros trabajos de crítica de la educación y de la cultura, Libro II, Vol. 1. Madrid: Abada Eds.

Benjamin, W. (2009). La obra de arte en la época de su reproductibilidad técnica. En: Estética y política. Buenos Aires: La Cuarenta.

Berardi, F. (2001). La fábrica de la infelicidad. Nuevas formas de trabajo y movimiento global. Madrid: Traficantes de sueños, Creative Commons.

Berger, P. y Luckman, T. (2005). La construcción social de la realidad. Barcelona: Amorrortu.

Berners-Lee, T. (2001). Tejiendo la web. El diseño origonal y el destino último www por su inventor. México: Siglo xxi.

Blondeau, O. (2004). Génesis y subversión del capitalismo informacional. En: O. Blondeau, et ál. Capitalismo cognitivo, propiedad intelectual y creación colectiva. Madrid: Traficantes de sueños.

Bourdieu, P. (2010). El sentido práctico. México: Siglo xxi.

Bourdieu, P. y Passeron, J. C. (2005). La distinción. México: Siglo xxI.

Borriaud, N. (2004). Post producción. La cultura como escenario: modos en que el arte reprograma el mundo contemporáneo. Buenos Aires: Adriana Hidalgo Editora.

Brea, J. L. (2007). Cultura RAM. Mutaciones de la cultura en la era de su distribución electrónica. Barcelona: Gedisa.

Brea, J. L. (2009). El net.art y la cultura que viene. Bogotá: Universidad Nacional de Colombia. 
Bringué, X. (2009). La generación interactiva en Iberoamérica, niños y adolescentes ante las pantallas. Navarra: Telefónica y Universidad de Navarra, Colección Telefónica, Ariel.

Bruner, J. (1991). Actos de significado, más allá de la revolución cognitiva. Madrid: Alianza.

Bruner, J. (2004). Realidad mental y mundos posibles: los actos de la imaginación que dan sentido a la experiencia. Barcelona: Gedisa.

Buckingham, D. (2002). Crecer en la era de los medios tras la muerte de la infancia. Barcelona: Morata.

Buckingham, D. (2008). Más allá de la tecnología: Aprendizaje infantil en la era de la cultura digital. Buenos Aires: Manantial.

Burbules, N. (1999). El diálogo en la enseñanza. Teoría y práctica, Buenos Aires: Amorrortu.

Burbules, N. (2006). Riesgos y promesas de las nuevas tecnologías de la información. Buenos Aires: Granica.

Cabero, J. (2001) Las nuevas tecnologías en el aula. ¿Una realidad o una utopía? En: FETE-UGT-GID (2001). Nuevas tecnologías aplicadas a la educación, pp. 1-11. Sevilla: Universidad de Sevilla..

Carli, S. (2002). Niñez, pedagogía y política. Transformaciones de los discursos acerca de la infancia en la historia de la educación argentina entre 1880 y 1955. Buenos Aires: UBA, Miño y Dávila.

Carli, S. (2003). El problema de la representación. Balances y dilemas. Buenos Aires: ubA, Miño y Dávila.

Carli, S. (Comp.), (2006). La cuestión de la infancia. Entre la escuela, la calle y el shopping. Buenos Aires: Paidós.

Carter, R. (2002). El nuevo mapa del cerebro. Barcelona: RBA, Col.

Casacuberta, D. (2003). Creación colectiva. En Internet el creador es el público. Barcelona: Gedisa.

Cascajosa-Virino, C. (Comp.), (2007). La caja lista: televisión norteamericana de culto. Barcelona: Leartes.

Cassirer, E. (2003). Filosofía de las formas simbólicas I. México: FCE.

Castells, M. (2003, 2006). La era de la información. Economía, sociedad y cultura, Volumen 1. La sociedad red. Madrid: Alianza.

Castells, M. (2007). Globalización y antiglobalización. En: Pánico en la globalización, pp. 36-44. Bogotá: FICA. 
CEPAL (2007). Plan de acción sobre la Sociedad de la Información de América Latina y el Caribe. Santiago: CEPAL.

Cibergolem (2005). La quinta columna digital. Anti-tratado sobre hiperpolítica. Barcelona: Gedisa.

Cobo, C. y Moravec, J. (2010, 2011). Aprendizaje invisible. Hacia una nueva ecología de la educación. Barcelona: UNA, Colección transmedia XXI.

Cobo, C. y Pardo, H. (2007). Planeta Web 2.o, inteligencia colectiva o medios Fast food. México, Barcelona: uvic, Flacso-México.

Corea, C. y Lewcowicz, I. (2004). Pedagogía del aburrido. Escuelas destituidas, familias perplejas. Buenos Aires: Paidós Educador.

Crawford, C. (2004). On Interactive storytelling. Berckeley: New readers.

Deleuze, G. (2006a). Post-scriptum sobre las sociedades de control. En: G. Deleuze. Conversaciones. Valencia: Pre-textos.

Deleuze, G. (2006b). Del Anti-Edipo a Mil mesetas. En: G. Deleuze. Conversaciones. Valencia: Pre-textos.

Deleuze, G. (2006c). Exasperación de la filosofía. El Leibniz de Deleuze. Buenos Aires: Cáctus.

Deleuze, G. (2007). Empirismo y subjetividad. Barcelona: Gedisa.

Deleuze G. y Guattari, F. (2008). Mil mesetas. Capitalismo y esquizofrenia. Valencia: Pretextos.

Debord, G. (2008). La sociedad del espectáculo. Buenos Aires: Ed. La Marca.

De Certeau, M. (2007, 2008). La invención de lo cotidiano 1. Artes de hacer. México: ITESO.

Dewey, J. (2011). Adresses and proceedings of the National Education Association. us: National Association of School Superintendents. Central College Association.

Díaz, C. J.; Amador, J. C. y Delgadillo, I. (2010). Emergencias de la memoria. Dos estudios sobre la infancia, la escuela y la memoria. Bogotá: Universidad Distrital, IPAZUD.

Díaz, C. J. y Amador, J. C. (2009). Hacia la comprensión de universos psico-culturales. Las fuentes vivas: memoria y narración. En: A. Serna (Comp.). Memorias en crisoles. Propuestas teóricas, metodológicas y estratégicas para los estudios de la memoria. Bogotá: Universidad Distrital, IPAZUd, Archivo de Bogotá. 
Diker, G. (2008). ¿Qué hay de nuevo en las nuevas infancias? Buenos Aires: Universidad Nacional General Sarmiento.

Dussel, I. y Gutiérrez, D. (Comp.), (2006). Educar la mirada. Políticas y pedagogías de la imagen. Buenos Aires: Manatial, Flacso.

Edwards, D. y Coll, C. (2006). Enseñanza, aprendizaje y discurso en el aula. Aproximaciones al estudio del discurso educacional. Madrid: Fund. Infancia y aprendizaje.

Eisner, E. (1995). Educar la visión artística. Barcelona: Paidós.

Elías, N. (1997). El proceso de la civilización. México: FCE.

Fabbri, P. (2000, 2003). El giro semiótico. Barcelona: Gedisa.

Fainhloc, B. (1999). La interactividad en la educación a distancia. Barcelona: Paidós.

Feixa, C. (2001). Generación @ la juventud en la era digital. En: Revista Nómadas 13, pp. 76-91. Bogotá: Universidad Central-Diuc.

Ferrés, J. (2008). La educación como industria del deseo. Un nuevo estilo comunicativo. Barcelona: Gedisa.

Frasca, G. (2009). Ludología. Consultado el 12 de marzo de 2009. Disponible en: www.ludology.org.

Freire, P. (2005). Pedagogía del oprimido. México: Siglo xxi.

Foucault, M. (1988). Technologies of the Self: A seminar with Michel Foucault. L. H. Martin, H. Gutman y P. H. Hutton (Eds.). Londres: Tavistock Publications.

Foucault, M. (1991). El sujeto y el poder. Bogotá: Carpe Diem

Foucault, M. (2005). Nacimiento de la biopolítica. México: FCE, 2005.

Foucault, M. (2007). Vigilar y castigar. El nacimiento de la prisión. Barcelona: Siglo XXI.

Gadotti, M. (1998, 2011). Historia de las ideas pedagógicas. México: Siglo XXI.

García-Canclini, N. (1995). Consumidores y ciudadanos. México: Grijalbo.

García-Canclini, N. (2004). Diferentes, desiguales y desconectados. Mapas de la interculturalidad. Barcelona: Gedisa.

García-Canclini, N. (2010). La sociedad sin relato. Buenos aires: Katz.

Gibson, W. (1984, 1989). Neuromante. Madrid: Minotauro. 
Goffman, E. (1959, 1993). La presentación de la persona en la vida cotidiana. Buenos Aires: Amorrortu.

Greimas, A. J. (1971, 1998). Semántica estructural: investigación metodológica. Madrid: Gredos.

Grossberg, L. (2006). Caught in the crossfire: Kids, politics and America's future. Londres: Verso.

Guattari, F. y Rolnik, S. (2006). Micropolítica: Cartografías del deseo. Traducción de Florencia Gómez. Madrid: Traficantes de Sueños.

Guinzburg, C. (2008). El paradigma indiciario. En: C. Guinzburg. Mitos, emblemas, indicios. Morfología e historia. Barcelona: Gedisa.

Grundy, Sh. (1994). Producto o praxis del currículo. Barcelona: Morata.

Gumbrecht, H. (2005). El oficio de la historia. Producción de presencia. México: Universidad Iberoamericana, Dpto. de historia.

Habermas, J. (2005). Conocimiento e interés. En: Conformismo o democracia. Bogotá: FICA.

Hall, S. (1994, 1997). Estudios culturales: Dos paradigmas. En: Revista Causas y azares 1, Buenos Aires.

Heidegger, M. (1998). Ser y tiempo. México: FCE.

Hine, C. (2002). Etnografía virtual. Barcelona: Ed. uoc.

Hobbes, T. (2007). Leviatán. Buenos Aires: Losada.

Huizinga, J. (2000). Homo ludens: el juego y la cultura. México: FCE.

Huergo, J. (2000). Comunicación/Educación. Itinerarios transversales. En: Comunicación-Educación, coordenadas, abordajes y travesías. Serie Encuentros, pp. 3-25. Bogotá: Universidad Central-Diuc, Siglo del Hombre Editores.

Huergo, J. (2006). Una guía de Comunicación/Educación, por las diagonales de la cultura y la política. En: Revista Virtual Nodos de Comunicación/Educación 5. Centro de Comunicación y Educación.

Igarza, R. (2009). Burbujas de ocio. Nuevas formas de consumo cultural. Buenos Aires: La Crujía.

Jenkins, H. (2008). Convergence Culture. La cultura de la convergencia de los medios de comunicación. Barcelona: Paidós.

Kaminsky, G. (2009). El yo minimalista y otras conversaciones. Buenos Aires: La marca ed. 
Kaplún, M. (1998). Una pedagogía de la comunicación. Madrid: La Torre.

Lacasa, P. (2011). Los Videojuegos. Aprender en mundos reales y virtuales. Barcelona: Morata.

Lago, S. (2008). Internet y cultura digital: La intervención política y militante. En: Revista Nómadas 28, pp. 102- 111. Bogotá: Universidad Central.

Landow, G. (1995) Hipertexto. La convergencia de la teoría crítica contemporánea y la tecnología. Barcelona: Paidós.

Latour, B. (2005). Reensamblar lo social. Una introducción a la teoría del actor-red. Buenos Aires: Manantial.

Lazzarato, M. (2006). Por una política menor. Acontecimiento y política en las sociedades de control. Madrid: Traficantes de sueños, Creative Commons.

Lazzarato, M. (2007). La filosofía de la diferencia y el pensamiento menor. Bogotá: Universidad Central-IEsco.

Ledoux, J. (1999). El cerebro emocional. Barcelona: Ariel.

Lessig, L. (2004). Cultura libre. Cómo los grandes medios usan la tecnología y las leyes para encerrar la cultura y controlar la creatividad. Traficantes de sueños, Cretaive Commons.

Lévy, P. (1999). ¿Qué es lo virtual? Barcelona: Paidós.

Lévy, P. (2004). Inteligencia colectiva. Por una antropología del ciberespacio. Washington: Organización.

Lévy, P. (2007). Cibercultura. La cultura de la sociedad digital. Barcelona: Anthropos, U. Autónoma Metropolitana.

Lindín, C. (2011). La autoría desmoronada en la Web x.o. Narraciones colectivas terrenales: una construcción del significado digital en libertad. En: J. A. Rodríguez (Ed.). Narratopedia. Reflexiones sobre narrativa digital, creación colectiva y cibercultura. Bogotá: Universidad Javeriana.

Luna, O. (2011). Hábitats digitales para la memoria, la presencia y la imaginación. En: J. A. Rodríguez (Ed.). Narratopedia. Reflexiones sobre narrativa digital, creación colectiva y cibercultura. Bogotá: Universidad Javeriana.

McLuhan, M. (1962, 1998). La galaxia Gutenberg. Toronto: University of Toronto press.

Maffesoli, M. (2004). El tiempo de las tribus. El ocaso del individualismo en las sociedades posmodernas. Buenos Aires: Siglo xxI.

Manovich, L. (2001). El lenguaje de los nuevos medios de comunicación. La imagen en la era digital. Barcelona: Paidós. 
Marín, M. y Muñoz, G. (2002). Secretos de mutantes. Música y creación en las culturas juveniles. Bogotá: Siglo del hombre, Universidad Central.

Martín-Barbero, J. M. (2003). De los medios a las mediaciones. Comunicación, cultura y hegemonía. Bogotá: Convenio Andrés Bello.

Martín-Barbero, J. M. (2004). Tecnicidades, identidades, alteridades: desubicaciones y opacidades de la comunicación en el nuevo siglo. Guadalajara: ITESO.

Marx, C. (1982). Introducción general a la crítica de la economía política/1857. México: Siglo xxI.

Mattelart, A. y Neveu, E. (2004). Introducción a los estudios culturales. Barcelona: Paidós.

Mead, M. (1977). Cultura y compromiso. El mensaje a la nueva generación. Barcelona: Granica.

Medina, M. (2007). Prólogo. En: P. Levy. Cibercultura, la sociedad digital. Barcelona: Anthropos.

Minzi, V. (2006) Los chicos según la publicidad. Representaciones de infancia en el discurso del mercado de productos para niños. En: La cuestión de la infancia. Entre la escuela, la calle y el shopping. Buenos Aires: Paidós.

Montagu, A. et ál. (2004). Cultura digital. Comunicación y sociedad. Buenos Aires: Paidós.

Morduchovicz, R. (2008). La generación multimedia, significados, consumos y prácticas culturales de los jóvenes. Buenos aires: Paidós.

Muñoz, G. et ál. (2011). Los mundos de vida de los jóvenes y niños en las pantallas. En: Revista Latinoamericana de ciencias sociales, niñez y juventud (9),1. Manizales: cINDE.

Muñoz, G. (2006). La comunicación en los mundos de vida juveniles. Hacia una ciudadanía comunicativa. Manizales: Universidad de Manizales, CINDE. Disponible en: www.unimanizales.edu.co.

Muñoz, G. (2008). Ensayo Comunicación y cultura. Doctorado Interinstitucional en Educación. Bogotá: Universidad Distrital.

Narodowski, M. (1999). Después de clase. Desencantos y desafíos de la escuela actual. Colección Educausa. Buenos Aires: Novedades Educativas.

Negroponte, N. (1990, 1995, 2000). Mundo digital. Barcelona: Ediciones B.

Nietzsche, F. (1970). Sobre verdad y mentira en sentido extramoral. En: Obras Completas, Vol. I, pp. 543-556. Buenos Aires: Ediciones Prestigio. 
O'Reilly, T. (2005). What is Web 2.o? Design patterns and business models for the next generation of Software. O'Reilly Network. Consultado el 15 de julio de 2010. Disponible en: http://www.oreillynet.com/pub/a/oreilly/tim/ news/2005/09/30/what-is-web-20.html.

Orozco, G. (1999). Medios, audiencias y mediaciones. En: Revista Comunicar 8, pp. 25- 30. Grupo Comunicar. Andalucía: Colectivo Andaluz para la educación en medios de comunicación.

Orozco, G. (2001). Audiencias: mediaciones y televisión pública. En: O. Rincón (Comp.). Televisión pública: del consumidor al ciudadano. Bogotá: Convenio Andrés Bello.

Orozco, G. (2010). Entre pantallas: nuevos roles comunicativos y educativos de los ciudadanos. En: R. Aparici, et ál. Educomunicación: más allá del 2.o. Barcelona, Gedisa.

Peirce, C. S. (1987). Fragmentos de obra lógica semiótica. Madrid: Taurus.

Piscitelli, A. (1998). Post-televisión. Ecología de los medios en Internet. Buenos Aires: Paidós.

Piscitelli, A. (2002). Ciberculturas 2.o: En la era de las máquinas inteligentes. Buenos Aires: Paidós.

Piscitelli, A. (2005). Internet, la imprenta del siglo XXI. Barcelona: Gedisa.

Piscitelli, A. (2009). Nativos digitales, dieta cognitiva, inteligencias colectivas y arquitecturas de participación. Montevideo: Santillana.

Postman, N. (2005). La desaparición de la niñez. Bogotá: upN. Traducción de Clara C. Bonilla $\mathrm{P}$.

Prensky, M. (2002). Digital natives, digital immigrants. In: On The horizon (9)5. October. UK: Мсв University Press.

Prieto-Castillo, D. (2010). Construir nuestra palabra de educadores. En: R. Aparici, et ál. Educomunicación: más allá del 2.o. Barcelona: Gedisa.

Rawls, J. (2006). Teoría de la justicia. México: FEC.

Rheingold, H. (2004). Multitudes inteligentes. Barcelona: Gedisa.

Rodríguez, J. A. (2008). El mundo virtual como dispositivo para la creación artística. En: Revista Nómadas 28, pp. 138-147. Universidad Central.

Rodríguez, J. A. (2011). Narrativas del ciberespacio. En: J. A. Rodríguez (Ed.). Narratopedia. Reflexiones sobre narrativa digital, creación colectiva y cibercultura. Bogotá: Universidad Javeriana. 
Rueda, R. (2003). Para una pedagogía del hipertexto: Una teoría entre la deconstrucción y la complejidad. Tesis doctoral. Universidad de las Islas Baleares. Consultado el 29/o8/o8. Disponible en: http://www.tesisenxarxa. net/TESIS_UIB/AVAILABLE/TDX-1002103-162409//trro.pdf.

Rueda, R. (2008). Cibercultura: Metáforas, prácticas sociales y colectivos en red. En: Revista Nómadas 28, pp. 8-19. Bogotá: Universidad Central.

Rueda, R. (2009). Convergencia tecnológica: síntesis o multiplicidad política y cultural. En: Revista Signo y Pensamiento, pp. 115-130. Bogotá: Pontificia Universidad Javeriana.

Rueda, R. y Quintana, A. (2004). Ellos vienen con el chip incorporado. Aproximación a la cultura informática escolar. Bogotá: Instituto para la Investigación Educativa y el Desarrollo Pedagógico.

Sarlo, B. (2010). Tiempo presente. Notas sobre el cambio de una cultura. Buenos Aires: Siglo XxI.

Sánchez, I. (2011). Ciberpragmática: las posibilidades del uso del lenguaje en entornos de comunicación virtual. Texto de trabajo. Consultado en julio 15 de 2011. Disponible en: http://ayp.unia.es/dmdocuments/evid_doco5.pdf.

Santos, C. et ál. (2003). Nuevas tecnologías y cultura. Barcelona: Anthropos, U. Autónoma Metropolitana.

Saussure, F. (2002). Curso de lingüística general. Buenos Aires: Losada.

Scolari, C. (2004). Hacer clic. Hacia una sociosemiótica de las interacciones digitales. Barcelona: Gedisa.

Scolari, C. (2008). Hipermediaciones. Elementos para una teoría de la comunicación digital interactiva. Barcelona: Gedisa.

Scolari, C. (2010). Interfaces para saber, interfaces para hacer. Las simulaciones digitales y las nuevas formas del conocimiento. En: R. Aparici, et ál. Educomunicación: más allá del 2.o. Barcelona: Gedisa.

Sen, A. (1999, 2000). Development as freedom. Oxford: University press.

Sibilia, P. (2008). La intimidad como espectáculo. Buenos Aires: FCE.

Spinoza, B. (2005). Ética demostrada según el orden geométrico. México: FCE.

Stallman, R. (2002, 2003). Software libre para una sociedad libre. Madrid: Traficantes de sueño y Creative commons.

Steinberg, S. y Kincheloe, J. (Comp.), (1997). Cultura infantil y multinacionales. Madrid: Morata. 
Toeffler, A. (1997). El shock del futuro. Bogotá: Plaza y Janés.

Turckle, Sh. (1995). La vida en la pantalla. La construcción de la identidad en la era de Internet. Barcelona: Paidós.

Varela, J. (1995). Categorías espacio-temporales y socialización escolar. Del individualismo al narcicismo. En: J. Larrosa (Ed.). Escuela, poder y subjetivación. Madrid: La piqueta.

Varela, M. (2008). La dinámica del cambio en los medios. La mirada de la TV., Youtube. En: Posgrado virtual FLACSO-Educación, imágenes y medios. Buenos Aires: FLACSO.

Vasilachis, I. (Coord.), (2007). Estrategias de investigación cualitativa. Barcelona: Gedisa.

Vásquez, T. y Pinilla, A. (2004). La televisión en familia y la familia en la televisión. Bogotá: Comisión Nacional de Televisión.

Valderrama, C. (2008). Colectivos y movimientos sociales en la red. En: Revista Nómadas 28. Bogotá: Universidad Central, IEsco.

Vizer, E. (2009). Dimensiones de la comunicación y de la información: la doble faz de la realidad. En: Revista Signo y pensamiento 28, p. 55. Bogotá: Universidad Javeriana.

Vygotski, L. S. (1996). El desarrollo de los procesos psicológicos superiores. Barcelona: Crítica.

Williams, R. (2008). Historia y cultura común. Antología. Madrid: Ed. Los libros de la catarata.

Yudice, G. (2002). El recurso de la cultura. Usos de la cultura en la era global. Barcelona: Gedisa.

Yus, F. (2001). Ciberpragmática. El uso del lenguaje en Internet. Barcelona: Ariel.

Zabala, I. (1997). Bajtin y el acto ético: una lectura al reverso. En: M. Bajtin. Hacia una filosofía del acto ético. De los borradores y otros escritos. Barcelona: Anthropos.

Zemelman, H. (2007). El ángel de la historia: determinación y autonomía de la condición humana. Barcelona: Anthropos.

Zukerfield, M. (2008). Capitalismo cognitivo, trabajo informacional y un poco de música. En: Revista Nómadas 28, pp. 52-65. Bogotá: Universidad Central. 


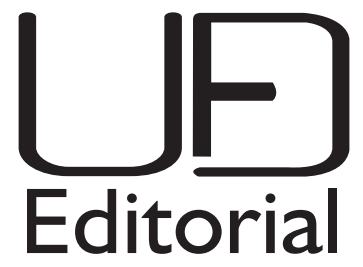

\author{
ESTE LIBRO FUE COMPUESTO EN CARACTERES \\ Georgia y Gill Sans 10/14,6 Puntos. \\ IMPRESO EN EL MES DE ENERO DE 2014 \\ EN LOS TALLERES DE JAVEGRAF. \\ Bogotá, Colombia. 2014
}

Amador Baquiro, Juan Carlos

Infancias, comunicación y educación : análisis de sus mutaciones / Juan Carlos Amador Baquiro.-- Bogotá : Editorial Universidad Distrital, 2013.

184 p. ; 24 cm. -- (Colección tesis doctoral)

ISBN 978-958-8832-39-5 / ISBN digital: 978-958-8832-40-1

1. Educación - Comunicación 2. Métodos de enseñanza

3. Innovaciones educativas 4. Materiales de enseñanza I. Tít.

II. Serie

$370.14 \mathrm{~cd} 21 \mathrm{ed}$.

A1431378

CEP-Banco de la República. Biblioteca Luis Ángel Arango 


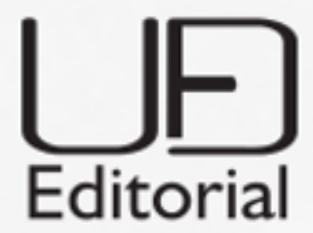

¿Qué relación existe entre las transformaciones provocadas por las nuevas formas de comunicación mediada tecnológicamente y las subjetividades de los niños y niñas? ¿La educación que orienta e implementa la escuela responde hoy a estas nuevas realidades? ¿Qué ocurre al incorporar computadores y garantizar conectividad en las prácticas pedagógicas? ¿Es posible plantear una ruta para transformar las prácticas pedagógicas en la escuela?

Aunque todas estas preguntas no van a ser resueltas completamente, la presente investigación se inscribe en el marco de estas preocupaciones, centrándose en los aspectos constitutivos de las prácticas de los niños y niñas en la comunicación digital interactiva (CDI-hipermediaciones), asumida como un escenario que propicia nuevos len guajes, saberes y experiencias. En este caso, la comprensión fenomenológica de estas prácticas comunicacionales permitió descifrar algunas de las expresiones más relevantes de las subjetividades emergentes de estos sujetos, las cuales se han estructurado en tres apartados: Mutación comunicacional, Mutaciones de la subjetividad y Otras educaciones y pedagogías, cada uno constituido por capítulos que presentan el objeto de la mutación en diálogo con referentes teóricos y metodológicos, y los resultados detallados de la indagación correspondiente.

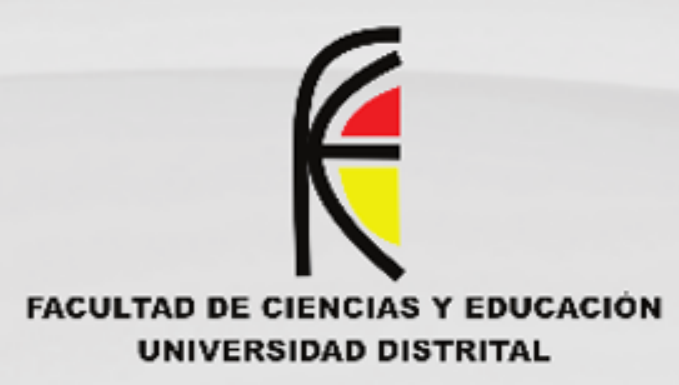

